\author{
UNIVERSIDADE DE SÃO PAULO \\ FACULDADE DE MEDICINA DE RIBEIRÃO PRETO \\ DEPARTAMENTO DE FISIOLOGIA
}

MELINA PIRES DA SILVA

\begin{abstract}
Modulação nitrérgica de canais para cátions ativados por hiperpolarização e nucleotídeo cíclico em neurônios do núcleo supraóptico
\end{abstract}

Ribeirão Preto

Fevereiro de 2015 


\section{Modulação nitrérgica de canais para cátions ativados por hiperpolarização e nucleotídeo cíclico em neurônios do núcleo supraóptico}

Tese apresentada à Faculdade de Medicina de Ribeirão Preto da Universidade de São Paulo, como pré - requisito para obtenção do título de Doutor em Ciências.

Área de Concentração: Fisiologia

Orientador: Prof. Dr. Wamberto Antonio Varanda

\section{Ribeirão Preto}

Fevereiro de 2015 


\section{FICHA CATALOGRÁFICA}

Autorizo a reprodução e divulgação total ou parcial deste trabalho, por qualquer meio convencional ou eletrônico, para fins de estudo e pesquisa, desde que citada à fonte.

da Silva, Melina Pires

Modulação nitrérgica de canais para cátions ativados por hiperpolarização e nucleotídeo cíclico em neurônios do núcleo supraóptico / da Silva Melina Pires; Orientador: Wamberto Antonio Varanda - Ribeirão Preto, 2015.

160 f.: il.

Tese apresentada à Faculdade de Medicina de Ribeirão Preto da Universidade de São Paulo. Departamento de Fisiologia. Área de concentração: Fisiologia.

1. Canais HCN. 2. Óxido Nítrico. 3. Ocitocina. 4. Vasopressina. 5. Snitrosilação. 
Nome: da Silva, Melina Pires

Título: Modulação nitrérgica de canais para cátions ativados por hiperpolarização e nucleotídeo cíclico em neurônios do núcleo supraóptico.

Tese apresentada à Faculdade de Medicina de Ribeirão Preto

da Universidade de São Paulo para obtenção

de título de Doutor em Ciências.

Aprovado em:

\section{Banca Examinadora}

Prof. Dr. Wamberto Antonio Varanda

Julgamento

Prof. Dra. Rita de Cássia A. Tostes Passaglia

Julgamento

Prof. Dr. Ricardo Maurício Xavier Leão

Julgamento

Prof. Dr. Laurival Antonio de Luca Junior

Julgamento

Prof. Dr. Aldo Rogelis Aquiles Rodrigues

Julgamento
Instituição:

Assinatura

Instituição:

Assinatura

Instituição:

Assinatura

Instituição:

Assinatura

Instituição:

Assinatura 
Dedico este trabalho a minha família que sempre lutou pela minha educação e soube entender minha ausência nos muitos momentos desde que ingressei na pós-graduação.

Ao meu noivo, amigo e companheiro de todas as horas, Davi, pelo incentivo, paciência e por ser meu exemplo de como fazer ciência. 


\section{Agradecimentos}

Desafio tão grande quanto escrever uma tese é dar o "muitíssimo" obrigado a todos àqueles que fizeram parte desta trajetória. Bem sei que corro o risco de não dar conta deste agradecimento como é merecido, porque esta não foi uma caminhada breve, mas uma travessia que muitas vezes parecia sem fim. Assim dedicarei algumas palavras àqueles que fizeram parte desta caminhada.

Inicio meus agradecimentos ao principal responsável pela qualidade desde trabalho, meu orientador Dr. Wamberto Antonio Varanda, pelo apoio, incentivo, disponibilidade, paciência e profissionalismo em todas as fases que levaram à concretização desta tese.

Aos meus pais, Antônio Carlos da Silva e Vânia Célia Pires da Silva pelo incentivo, compreensão e encorajamento durante todo este período.

Ao meu noivo Davi pela ajuda nos momentos críticos, pelo companheirismo, amizade, paciência, compreensão, apoio, amor, e por ter feito do meu sonho o nosso sonho!

Aos técnicos e colegas de laboratório, Fernandinho, André, Junia, Pedro e Carlos, pelos momentos de entusiasmo partilhados em conjunto, e claro, pela amizade.

As minhas grandes e inesquecíveis amigas Lígia, Junia, Marlusa, Alexandra e Daniela por fazerem parte, sem dúvida alguma, dos melhores momentos desta jornada.

A estimada amiga Leni por me acolher com tanto carinho, pelos valiosos conselhos, por ouvir minhas angustias, e por tornar meus dias mais leves. Foi muito bom poder contar com você!

Ao professor Dr. André Mecawi pela colaboração nos experimentos de RT-qPCR, pelas discussões dos protocolos experimentais, mas principalmente pela amizade de longa data. 
Ao professor Dr. José Antunes Rodrigues por gentilmente nos fornecer os anticorpos utilizados neste estudo, permitir à utilização da máquina de RT-qPCR e acima de tudo pelo exemplo, inspiração, e incentivo na área de fisiologia.

Ao pessoal da secretária do departamento de fisiologia, Cláudia, Elisa e Fernando, muito obrigado!

Ao bioterista Léo pelo cuidado com os animais.

A CAPES, FAPESP, CNPQ e FAEPA, pelo apoio financeiro.

E porque ninguém vence sozinho... MUITÍSSIMO OBRIGADO A TODOS! 
"Quem se arrisca a andar por ares nunca antes respirados ou pensar fora da curva tem grandes chances de encontrar pedras no caminho. No entanto, ninguém é digno de contribuir para a ciência se não usar suas dores e insônias nesse processo. Não há céu sem tempestade! Risos e lágrimas, sucessos e fracassos, aplausos e vaias fazem parte do currículo de cada ser humano, em especial daqueles que são apaixonados por produzir novas ideias..."

(Augusto Cury) 


\section{Resumo}

O núcleo supraóptico (SON), uma das várias áreas hipotalâmicas envolvidas no equilíbrio hidroeletrolítico corporal, é de suma importância na complexa rede de sistemas fisiológicos que atuam na manutenção da homeostase. Este núcleo é constituído por um grupamento de neurônios magnocelulares (MNCs) responsáveis pela síntese e liberação de vasopressina e ocitocina, neuropeptídios cujos principais efeitos se fazem sobre a excreção de água e sal pelos rins. Alterações da osmolalidade plasmática implicam em mudanças funcionais intrínsecas (propriedades de membrana) e extrínsecas (sinápticas) na excitabilidade desses neurônios, com consequências para a liberação desses neuropeptídios. Além da osmolalidade, outros fatores são capazes de modular a excitabilidade dos MNCs, dentre elas o óxido nítrico (NO). Vários estudos têm mostrado que o NO desempenha um papel neuromodulador importante nesses neurônios, resultando na inibição da excitabilidade dos MNCs durante condições isotônicas e hipertônicas. Além disso, estas respostas são independentes das conexões sinápticas e envolvem a modulação de canais para cátions ativados por hiperpolarização e nucleotídeo cíclico (HCN). Entretanto, ainda é desconhecido à origem deste mensageiro neural, o envolvimento de outros tipos celulares nesta resposta, os mecanismos de sinalização utilizados pelo $\mathrm{NO}$ na modulação dos canais $\mathrm{HCN}$, se esta modulação também ocorre em situações de aumentos de osmolaridade plasmática, e se há diferenças na modulação nitrérgica entre os fenótipos celulares. Assim, dada a importância deste núcleo para a manutenção do meio interno, elucidar os mecanismos pelo qual o NO modula os neurônios magnocelulares do SON torna-se essencial para o entendimento do controle da sua excitabilidade elétrica. Desta forma, considerando que: 1) os neurônios magnocelulares expressam a enzima para a síntese do NO em condições isotônicas e hipertônicas; 2) que os efeitos do NO parecem envolver, principalmente, a guanilato ciclase solúvel com consequente produção de cGMP; e 3) que os canais HCN são modulados por este 
segundo mensageiro, nós hipotetizamos que os MNCs são capazes de produzir NO independente de outros tipos celulares e do fenótipo celular, e que a modulação nitrérgica dos canais HCN envolve a produção de cGMP. Frente a isso, este projeto teve como objetivo: 1) investigar o envolvimento das células gliais na modulação nitrérgica observada nos MNCs; 2) desvendar a origem do NO; 3) estudar as vias de sinalização da modulação nitrérgica sobre os canais HCN 4) avaliar se os efeitos do NO nos canais HCN também ocorre durante estímulo hiperosmótico agudo, e 5) se há diferença na modulação do NO em relação ao fenótipo celular. Para tanto, utilizamos a eletrofisiologia celular, essencialmente a técnica de "patch clamp" em fatias do SON e neurônios isolados. Experimentos de fluorescência foram realizados para a detecção da atividade intracelular do NO com o intuito de elucidar a origem deste mensageiro neural. Além disso, técnicas de biologia celular e molecular também foram utilizadas para caracterizar o fenótipo da célula que se está registrando, uma vez que 3 tipos já foram descritos neste núcleo e podem responder de maneira diferente ao mesmo estímulo. Até o presente nossos resultados mostraram que: 1) A modulação nitrérgica nos MNCs não envolve células gliais, 2) O NO é produzido pelos neurônios magnocelulares durante estímulo hipertônico, e este processo é dependente das alterações da osmolalidade, mas não da atividade elétrica dos neurônios frente ao estímulo; 3) Esta modulação ocorre por um mecanismo dependente de S-nitrosilação e independentemente da formação de cGMP; 4) a modulação nitrérgica nos canais $\mathrm{HCN}$ não difere entre os diferentes tipos de fenótipos encontrados e também ocorre durante aumentos da osmolaridade plasmática. Frente a estes resultados podemos concluir que a excitabilidade dos neurônios magnocelulares do SON é essencialmente determinada por um efeito do NO sobre os canais HNC por um mecanismo dependente de S-nitrosilação. Desta forma, o NO apresenta-se como mais uma molécula nesse complexo mecanismo de manutenção do equilíbrio hidroeletrolítico do organismo.

Palavras Chaves: 1. Canais HCN, 2. Óxido Nítrico, 3. Ocitocina, 4. Vasopressina, 5. Snitrosilação. 


\begin{abstract}
The hypothalamic supraoptic nucleus ( $\mathrm{SON}$ ) plays an importante role in the complex systems network that operates to maintain the hydroelectrolytic balance of the body. The nucleus is formed by a cluster of neurons (magnocellular neurosecretory cells - MNCs) responsible for the synthesis and secretion of vasopressin and oxytocin, whose main effects are on the excretion of water and salt by the kidneys. Changes in plasma osmolality lead to intrinsic (membrane properties) and extrinsic (synaptic inputs) functional changes in these neurons, with consequences for neuropeptides release. Furthermore, besides osmolality, studies have shown that the electrical excitability of MNCs can be modulated by several factors, including nitric oxide (NO). Previous studies of our group, demonstrated that NO inhibits the excitability of MNCs during isotonic and hypertonic conditions and that this responses are independent of synaptic connections and involve the hyperpolarizationactivated cyclic nucleotide-gated channels $(\mathrm{HCN})$. However, some points remained unclear, such as: What is the origin of NO? Are there other cell types involved in this response? What signaling pathway does NO use to modulate HCN channels? Does NO modulate HCN channels during changes in the plasma osmolality? Are there differences in the nitrergic modulation according to cellular phenotypes? Considering that: 1) MNCs express the enzyme for nitric oxide synthesis, in isotonic and hypertonic conditions; 2) the NO effects involve, mainly, activation of guanylate cyclase with consequent increase in the cGMP production, and that 3) $\mathrm{HCN}$ channels are modulated by this second messenger, we hypothesize that MNCs are able to produce NO independently of other cells and cellular phenotypes, and that nitrergic modulation of $\mathrm{HCN}$ channels involves the guanylate cyclase activation. To answer those questions and to test our hypothesis, we used cellular electrophysiology, essentially Whole cell patch clamp using slices of the SON and isolated neurons. Fluorescence experiments were also used to detect the intracellular activity of NO in order to clarify the
\end{abstract}


origin of this neuronal messenger. In addition, cellular and molecular biology approaches were also used to characterize the phenotype of recorded cells, since 3 distinct cellular types have been described in this nucleus. Our results demonstrate that: 1) NO is produced by MNCs during hypertonic stimulation, and this process is dependent on changes in osmolality, but not on the electrical activity of MNCs in response to the stimulus; 2) NO modulates the electric excitability of the neurons by acting on $\mathrm{HCN}$ channels and it does not differ among cellular phenotypes; and 3) the effect of NO occurs by a mechanism dependent of Snitrosylation and independently of cGMP production. Considering these results we may conclude that electrical excitability of magnocellular neurons of the supraoptic nucleus is essentially determined by an effect of $\mathrm{NO}$ on $\mathrm{I}_{\mathrm{h}}$ currents by a mechanism dependent of $\mathrm{S}$ nitrosylation. Acting on $\mathrm{HCN}$ channels, $\mathrm{NO}$ is another player in the complex set of mechanisms controlling the hydroelectrolytic balance.

Key Words: 1. HCN Channels, 2. Nitric Oxide, 3. Oxytocin, 4. Vasopressin, 5. Snitrosylation. 


\section{Lista de Abreviaturas}

ACSF - Líquido Céfalo Raquidiano Artificial.

HCN - Canais para Cátions Ativados por Hiperpolarização e Nucleotídeo Cíclico.

I - Corrente.

$\boldsymbol{I}-\boldsymbol{V}$ - Relação Corrente x Voltagem.

$\mathbf{I}_{\mathbf{h}}$ - Corrente Ativada por Hiperpolarização.

MNCs - Neurônios Magnocelulares.

NO - Óxido Nítrico.

NOSc - Sintase Constitutiva do Óxido Nítrico.

NOSe - Sintase Endotelial do Óxido Nítrico.

NOSi - Sintase Induzida do Óxido Nítrico.

NOSn - Síntase Neural do Óxido Nítrico.

OT - Ocitocina.

QO - Quiasma Óptico.

RNAm - RNA mensageiro.

SON - Núcleo Supraóptico.

PVN - Núcleo Paraventricular.

VP - Vasopressina. 


\section{Lista de Figuras}

Figura 1. Síntese do Óxido Nítrico. Na presença de NADPH, oxigênio e alguns cofatores (tetrahidrobiopterina (BH4), Mononucleotídeo de Flavina (FMN), flavina adenina dinucleotídeo (FAD)) a sintase do óxido nítrico juntamente com o cálcio catalisa a reação transformando L-arginina em NO e citrulina. O NO uma vez formado, produzirá efeitos autócrinos e/ou parácrinos, bem como feedback negativo sobre a enzima NOS. Já a citrulina será convertida em arginina succinato, e Larginina pela ação da arginina succinato sintase e liase (33).

Figura 2. Esquema de s-nitrosilação de proteínas. Após ser sintetizado, o NO se liga a resíduos de cisteína da proteína resultando em um composto nitrosilado. Extraído de da Silva e cols., 2014 (33)

Figura 3. Fotomicrografias de fatias contendo o núcleo supraóptico. A) Em A, um esquema adaptado de Paxinos e Watson (115) mostrando a localização anatômica do SON (setas vermelhas), dorso-lateral ao quiasma óptico (och). Em B, uma fotomicrografia de uma fatia hipotalâmica de 230 $\mu \mathrm{m}$ de espessura, a seta em vermelho indica a localização do núcleo. Em $\mathbf{C}$, células visualizadas com o auxílio de um sistema de detecção de luz infravermelha. A micropipeta em contacto com uma célula estabelece a configuração Whole cell. SON - núcleo supraóptico

Figura 4. Marcação do NO pelo indicador DAF-FM. Imagens representativas de uma fatia do SON incubado com o indicador fluorescente da produção de NO, DAF-FM, visualizado em campo claro (A) e durante a excitação do indicador $(\mathbf{B})$. Linha tracejada em $\mathbf{B}$ representa a pipeta de vidro utilizada para registros de patch clamp. (DAF-FM: Excitação $=488 \mathrm{~nm} ; \quad$ Emissão= 515 $\mathrm{nm})$

Figura 5. Efeitos do inibidor do metabolismo glial na modulação nitrérgica dos neurônios magnocelulares do SON. A mostra traçados típicos da atividade intrínseca (registros feitos na presença de bloqueadores sinápticos - picrotoxina, CNQX e DL-AP5), de um dos neurônios do grupo, analisados após a incubação com o bloqueador do metabolismo glial fluorocitrato e com o substrato do NO, L-arginina $(500 \mu \mathrm{M})$. Em A1 tem-se as médias da frequência de disparo de potenciais de ação dos neurônios analisados $(n=7)$. Não houve diferença estatística entre os grupos $(5,6 \pm 0,9 \mathrm{~Hz}$ x 5,8 $\pm 1,4$ $\mathrm{Hz} ; \mathrm{p}>0,05)$. A análise da frequência foi realizada utilizando 1 min de registro de cada condição experimental.

Figura 6. Modulação nitrérgica durante a retração glial por desidratação crônica. A e $B$ são traçados típicos de voltagem obtidos de um dos neurônios de cada grupo analisados na situação controle (na presença de inibidores sinápticos - picrotoxina, CNQX e DL-AP5), e na presença dos 
inibidores mais $500 \mu \mathrm{M}$ de L- Arginina. Os registros mostram a atividade espontânea do neurônio durante 1 min de registro. Em A1 e B1 os gráficos de barras resumem os efeitos obtidos em 11 neurônios com 7 deles apresentando uma redução $(4,6 \pm 0,6 \mathrm{~Hz}$ x 3,4 $\pm 0,4 \mathrm{~Hz}$, Inibidores e Inibidores + L-arginina respectivamente; $\mathrm{p}<0,05)$ e os outros 4 , um aumento da frequência de potenciais de ação $(4,5 \pm 0,9 \mathrm{~Hz} \quad \mathrm{x} \quad 6,4 \pm 1,4 \mathrm{~Hz} ; \mathrm{p}<0,05)$. Teste $\mathrm{t}$ paramétrico para ambos os grupos.

Figura 7. Inibição da enzima NOS aumenta a frequência de disparos dos neurônios MNCs após a retração glial. A, Traçados representativos da atividade intrínseca de um neurônio do grupo durante o controle, somente na presença de inibidores sinápticos, e após a superfusão com os inibidores mais o inibidor da NOS, L-NAME (100 $\mu \mathrm{M})$. A1, o gráfico de barras representa as médias ( \pm epm) obtidas de 8 neurônios registrados. Na presença do L-NAME houve um aumento na frequência de disparo quando comparado com os inibidores $(4,5 \pm 0,7 \mathrm{~Hz}$ x $2,9 \pm 0,7 \mathrm{~Hz}$, respectivamente $-\mathrm{n}=8 ; \mathrm{p}<0,05-$ teste t paramétrico).

Figura 8. Caracterização fenotípica eletrofisiológica. Em A, registro de um neurônio vasopressinérgico obtido a partir de pulsos hiperpolarizantes de -40 a $-135 \mathrm{mV}$. A1, relação $I-V$ obtida a partir dos pontos delimitados pela linha vermelha tracejada. Note a linearidade da resposta. B e B1, registro de um neurônio ocitocinérgico e relação $I-V$ com retificação em voltagens mais despolarizadas que -60 mV, indicando a presença da corrente retificadora de saída. C e C1 registro de um neurônio ocitocinérgico e relação $I-V$ com retificação de entrada observada em voltagem mais hiperpolarizadas que $-80 \mathrm{mV}$. D e E, distribuição percentual dos fenótipos eletrofisiológicos dos neurônios que foram superfundidos com o substrato do NO (L-arginina) e inibidor da NOS (L-NAME) respectivamente.

Figura 9. Distinção fenotípica utilizando protocolo eletrofisiológico: A, B e C traçados representativos de neurônios ocitocinérgicos distinguidos pela presença de correntes retificadores de saída (SOR), entrada (IR) ou ambas (SOR/IR) obtidos em resposta a pulsos de voltagem hiperpolarizantes de $-40 \mathrm{mV}$ à $-135 \mathrm{mV}$ em passos de $-10 \mathrm{mV}$. D - traçado representativo de um neurônio vasopressinérgico. Os gráficos de barras resumem os diferentes tipos de correntes encontradas (E) e a separação fenotípica de acordo com o protocolo eletrofisiológico (F)

Figura 10. Identificação de neurônios magnocelulares pelo fenótipo molecular: Em um total de 74 neurônios registrados utilizando o protocolo eletrofisiológico, 43 foram caracterizados molecularmente como vasopressinérgicos, 13 como ocitocinérgicos e 18 como intermediários, expressando ambos os RNAm. Para maiores detalhes da análise e caracterização dos fenótipos utilizando PCR em tempo real, ver metodos 3.5. 
Figura 11. Correlação eletrofisiológica molecular. O gráfico de barras compara o fenótipo de 74 neurônios identificados tanto pela eletrofisiologia (barras pretas) quanto pelo RT-qPCR (barras cinza). De 11 neurônios identificados como vasopressinérgico pela eletrofisiologia, 9\% $(n=1)$ foi identificado como ocitocinérgicos, $64 \%(n=7)$ foram vasopressinérgicos e $27 \%(n=3)$ como intermediários pelo RT-qPCR. Por outro lado, de 63 neurônios eletrofisiologicamente identificados como neurônios ocitocinérgicos, $57 \%(\mathrm{n}=36)$ foram identificados como vasopressinérgicos, $24 \% \quad(\mathrm{n}=15)$ como intermediários e somente $19 \%(\mathrm{n}=12)$ como ocitocinérgicos.

Figura 12. Caracterização fenotípica de neurônios magnocelulares: Fotomicrografias representativas obtidas de dois neurônios imunohistoquímicamente identificados. Os neurônios foram preenchidos com biocitina $(0,2 \%)$ durante o registro eletrofisiológico e revelados pela estreptavidina conjugada com Alexa fluor 350 (vermelho -A1 e B1). Em seguida, os neurônios foram marcados para vasopressina (A2 e B2) e ocitocina (A3 e B3) e a identificação do fenótipo foi feita pela colocalização (A4 e B4). Os painéis superiores mostram um neurônio registrado eletrofisiologicamente e imunohistoquímicamente positivo para ocitocina e os inferiores para vasopressina. A barra branca corresponde a $15 \mu \mathrm{m}$. O gráfico de barras representa a distribuição fenotípica dos neurônios de acordo com cada técnica: imunofluorescência, RT-qPCR e com o protocolo eletrofisiológico (C). Uma alta correlação entre a imunofluorescência e qPCR pode ser observada, no entanto o mesmo não é verdadeiro quando comparamos estas técnicas com a eletrofisiologia.

Figura 13. Identificação fenotípica de neurônios magnocelulares do PVN lateral pela eletrofisiologia. Neurônios magnocelulares do PVN lateral $(n=22)$ foram identificados pelo protocolo electrofisiológico, seguindo os mesmos critérios descritos na seção 3.3 para neurônios do SON. Quatro relações $I-V$ foram encontradas no PVN lateral, sendo três delas correntes retificadoras, e uma linear (A, B, C e D respectivamente). A1, B1, C1 e D1 mostram as médias das relações $I-V$ para cada caso encontrado. Dos 22 neurônios registrados, 19 apresentaram correntes retificadoras (5 SOR; 11 IR e 3 SOR/IR) que caracterizaram essas células como ocitocinérgicas, e 3 tiveram uma relação $I-V$ linear e foram identificados como vasopressinérgicas. O gráfico de barras resume os dados encontrados em relação às retificações (E) e a classificação fenotípica, de acordo com o protocolo utilizado $(\mathbf{F})$

Figura 14. Caracterização molecular do fenótipo dos neurônios magnocelulares do PVN lateral. A mostra a distribuição do fenótipo molecular dos neurônios previamente distinguidos pelo protocolo eletrofisiológico. Das três células identificadas como vasopressinérgica pela eletrofisiologia, 2 também foram caracterizadas como vasopressinérgica pelo RT-qPCR e uma como ocitocinérgica (B). Entretanto das 19 células ocitocinérgicas (presença das correntes retificadoras), somente 3 foram identificadas como ocitocinérgica pelo RT-qPCR. Seis cédulas expressaram somente RNAm para vasopressina. 
Figura 15. Desequilíbrio hidroeletrolítico altera a proporção de fenótipos dos MNCs. Fotomicrografias mostrando neurônios imunorreativos para VP (vermelho) e OT (verde) em situação controle (A), após restrição hídrica (B), e sobrecarga salina $(\mathbf{C})$. A3- C3 representa a sobreposição das imagens. O Gráfico de barras em $\mathbf{D}$ resume o número de neurônios imunorreativos encontrados para cada condição experimental. A estatística foi realizada utilizando ANOVA One Way não paramétrica com pós-teste de Bonferroni $* * \mathrm{p}<0,005$. Barras horizontais $=15 \mu \mathrm{m}$. OC $=$ quiasma óptico.

Figura 16. Efeito do óxido nítrico nos canais $\mathrm{HCN}$ em neurônios magnocelulares isolados. Em A, estão representados traçados típicos obtidos em um neurônio do grupo demonstrando o efeito da superfusão com L-arginina, seguida da aplicação do bloqueador específico ZD7288. Observa-se uma redução da corrente total sensível ao ZD7288. Em D,E a corrente subtraída (L-arginina - ZD7288) é evidenciada numa relação corrente voltagem e comparada com o grupo controle. Na relação $I-V$ em $\mathbf{B}$, nota-se que quando os neurônios são submetidos a L-arginina $(500 \mu \mathrm{M})$ há uma redução expressiva da amplitude da corrente total quando comparada com o controle $(-19 \pm 5 \mathrm{pA} \times-6,8 \pm 1,8 \mathrm{pA}$, em -135 $m V, n=9 p<0,05)$. Em $\mathbf{C}$, traçado representativo de um neurônio do grupo demonstrando a ativação da corrente, em - $135 \mathrm{mV}$, ajustada com uma exponencial simples (em vermelho) para calcular a constante de tempo do processo. O grupo controle está representado em preto e o grupo submetido a L-arginina está representado em cinza. O gráfico de barras, em $\mathbf{D}$, resume a média do grupo no controle e após o tratamento com L-arginina. Note o aumento na constante de tempo na presença da Larginina.

Figura 17. Hipertonicidade aumenta a produção de NO em neurônios do supraóptico. A Evolução temporal da produção de NO de um único neurônio isolado do grupo na condição controle, durante o estimulo hipertônico e após tratamento com doador de NO (SIN1 $100 \mu \mathrm{M})$. As figuras no topo do gráfico representam "surface plots" do mesmo neurônio em cada condição experimental e a barra colorida, de cores frias a cores mais quentes, indica o aumento na produção de NO. B média $\Delta \mathrm{F} / \mathrm{F}_{0}$ (media \pm epm) obtida de 13 células em 3 experimentos independentes. $\Delta \mathrm{F}=\left(\mathrm{F}-\mathrm{F}_{0}\right)$ é a diferença entre a fluorescência obtida em um intervalo de tempo (F) e a fluorescência de fundo ( "background") $\left(\mathrm{F}_{0}\right)$. A média dos valores foi calculada com os maiores valores de $\Delta \mathrm{F} / \mathrm{F}_{0}$ para cada situação.

Figura 18. Imunofluorescência para neurônios vasopressinérgicos e ocitocinérgicos do SON isolados. Os neurônios isolados foram incubados com anticorpos específicos para identificação fenotípica (vasopressina em vermelho e ocitocina em verde). A colocalização é mostrada em amarelo em F e I. Dois tipos de morfologia neuronal foram identificados após 24 horas em cultura: Neurônios circulares (D) e com axônios e dendritos (G). A, B e C são experimentos controles somente com 
anticorpo secundário e na presença de DAPI (marcador nuclear). Escala: 7,5 $\mu \mathrm{m}$ (A-F) e $25 \mu \mathrm{m}$ (GI)

Figura 19. Imunofluorescência em fatias do SON. A, neurônios vasopressinérgicos marcados com anticorpo anti-VP (1:500 Guinea Pig anti-( $\left.\operatorname{Arg}^{8}\right)$-Vasopressina - Vermelho). B, neurônios marcado com anticorpo anti-OT (1:500 anti Rabbit - Verde). C, experimento controle somente com anticorpo secundário. Colocalização é mostrada em D. Note a ausência de colocalizações. QO = quiasma óptico

Figura 20. Hipertonicidade estimula a produção de NO nos neurônios magnocelulares do SON. Em A, evolução temporal da produção do NO durante controle, o estímulo hipertônico e lavagem (círculos preenchidos) ou na presença do inibidor da sintase do óxido nítrico (círculos vazios). Durante o estímulo hipertônico houve um aumento da fluorescência e sua volta próximo aos níveis basais ocorreu com a lavagem, efeito não observado na presença do L-NAME. B resume os resultados obtidos em cada situação experimental. $\Delta \mathrm{F}=\left(\mathrm{F}-\mathrm{F}_{0}\right)$ é a diferença entre a fluorescência obtida em um intervalo de tempo $(\mathrm{F})$ e a fluorescência de fundo ("background") $\left(\mathrm{F}_{0}\right)$. A média dos valores foi calculada com os maiores valores de $\Delta \mathrm{F} / \mathrm{F}_{0}$ para cada situação. . .75

Figura 21. Frequência de disparo não determina a produção de NO. Frequência de disparo dos neurônios foi alterada por injeções de corrente hiperpolarizante (diminuição) ou despolarizante (aumento) em células submetidas a condições de tonicidade indicados em cada situação experimental. (A) Decurso temporal da produção de NO em condições isotônicas e em repouso, após exposição das células a hipertonicidade e hiperpolarização e ao voltar para isotonicidade, como indicado pelas setas. (B) Fluorescência medida sob condições isotônicas e despolarização da célula, a fim de aumentar a frequência de disparo. O painel (C) mostra uma situação em que as células foram expostas a hipotonicidade. A fluorescência das células registrada está representada pelos círculos abertos (A1, B1 $\mathrm{n}=7$ e $\mathbf{C 1} \mathrm{n}=8$ ) e as células vizinhas que serviram como controle positivo por círculos fechados (A1 n=32; B1 n=101 e C1 n=86). Os gráficos de barras resumem a frequência de disparo dos neurônios registrados para cada caso. Os traçados nos gráficos são representativos de cada situação e as escalas de voltagem e tempo mostradas em $\mathbf{C}$ são valida para todos os registros. Os dados foram expressos como média \pm epm.

Figura 22. Canais HCN contribuem para excitabilidade dos neurônios do SON. Traçado representativo de um neurônio do grupo ilustrando os feitos do ZD7288 na frequência de disparo dos MNCs e no número de potenciais durante injeções de corrente positiva (A, E e E1). Em C, o mesmo traçado exposto em A, ampliado para visualizar melhor os efeitos do ZD7288 na cinética do potencial de ação. A linha vermelha representa o ajuste de uma exponencial simples na fase de despolarização pós-potencial, e como demonstrado o ZD parece reduzir a constante de tempo deste processo. Os 
gráficos em $\mathbf{B}$ e $\mathbf{E 2}$ resumem a média \pm epm de 12 neurônios registrados. Como demonstrado em $\mathbf{D}$, D1 e D2 a resistência de entrada dos neurônios, medida por injeções de corrente negativa (0 a -50 pA) não foi significativamente alterada na presença do ZD quando comparado ao controle.

Figura 23. Modulação nitrérgica nos canais HCN é independente de cGMP. A, B e C representam traçados de corrente evocados por pulsos de voltagem de -50 a $-135 \mathrm{mV}$, com duração de 3 segundos, na presença de três concentrações distintas do inibidor da guanilato ciclase solúvel (ODQ $3 \mu \mathrm{M}, 30$ $\mu \mathrm{M}$ e $100 \mu \mathrm{M})$, seguido do inibidor da corrente $\mathrm{I}_{\mathrm{h}}$, ZD7288 $(50 \mu \mathrm{M})$. Correntes $\mathrm{I}_{\mathrm{h}}$ obtidas pela subtração digital $(\mathbf{d , e})$. A1, B1 e C1 relação corrente x voltagem para o componente sensível a ZD7288. Não foram observadas alterações significativas na corrente $I_{h}$ em nenhuma das concentrações utilizadas. Controle $v s$ ODQ: $3 \mu \mathrm{M}(-33,3 \pm 7,6 \mathrm{pA} v s 33 \pm 6,8 \mathrm{pA}), 30 \mu \mathrm{M}(30,6 \pm 4 \mathrm{pA} v s-37,2 \pm$ $5,4 \mathrm{pA})$ e $100 \mu \mathrm{M}(-48,7 \pm 8,7 \mathrm{pA} v s-45,3 \pm 13,3 \mathrm{pA}) . \mathrm{p}>0,05$ para todas as concentrações. Oito células foram registradas para cada concentração utilizada.

Figura 24. Modulação nitrérgica dos canais HCN é independente de cGMP. A relação $I-V$ foi construída utilizando-se o mesmo protocolo descrito anteriormente e demonstra o efeito da L-arginina na presença do inibidor da guanilato ciclase. Mesmo na presença do bloqueador a L-arginina reduziu significativamente a corrente $I_{h}$ sugerindo uma via independente de cGMP. (-48 \pm 14 pA x $-24,7 \pm 10$ $\mathrm{pA}, \mathrm{n}=5) . * \mathrm{p}<0,05-$ Teste $\mathrm{t}$ pareado

Figura 25. Modulação nitrérgica dos canais $\mathbf{H C N}$ é dependente de s-nitrosilação. Em A e B, traçados representativos de registros de corrente $I_{h}$ na presença do bloqueador NEM, NEM + Larginina seguido de ZD7288. Gráfico $\mathbf{A 1}$ mostra a relação $I-V$ da média de neurônios registrados na presença do bloqueador da S-nitrosilação $(\mathrm{NEM}-300 \mu \mathrm{M})$. Note que na presença do bloqueador houve um aumento na corrente basal indicando que o canal é modulado por oxidações dos resíduos de cisteína $(-33,2 \pm 10 \mathrm{pA}$ vs $81,2 \pm 13 \mathrm{pA}$ em $-135 \mathrm{mV}$, controle e nitrosilado respectivamente, $\mathrm{n}=11$; p $<0,05)$. Em B1, o gráfico com a relação $I-V$ resume a média dos neurônios registrados na presença da L-arginina demonstrando que na presença do bloqueador da S-nitrosilação a L-arginina não foi capaz de alterar a corrente $I_{h}$ apontando a via utilizada pelo NO para modular os canais $\mathrm{HCN}(-59,2 \pm 15$ pA vs $-59 \pm 11 \mathrm{pA}$ em $-135 \mathrm{mV} ; \mathrm{n}=10 ; \mathrm{p}>0,05)$. Não foi observado diferenças entre os fenótipos celulares.

Figura 26. Neurônios magnocelulares são s-nitrosilados endogenamente. $O$ gráfico $I-V$ mostra $o$ efeito da denitrosilação nos canais HCN. Como podemos observar, na presença do ascorbato houve um aumento na magnitude da corrente $\mathrm{I}_{\mathrm{h}}$ indicando uma s-nitrosilação endógena ( $-9,8 \pm 14 v s-16,8 \pm$ $8,5, \quad \mathrm{n}=6 ; \quad \mathrm{p}<0,05)$. Não foi observado diferenças entre os fenótipos celulares 
Figura 27. Hipertonicidade modula os canais $\mathrm{HCN}$ em neurônios magnocelulares. Em A e B, traçados típicos obtidos de um neurônio do grupo na condição controle (a), na presença do estímulo hipertônico (b) ou hipertônico mais L-NAME (B-b), seguido da aplicação do bloqueador dos canais HCN ZD7288 (c). d,e representam o componente sensível ao ZD7288 em cada condição experimental. C e D, as relações I-V das médias das correntes sensíveis ao ZD7288 (corrente $\mathrm{I}_{\mathrm{h}}$ ) nas mesmas condições experimentais descritas acima. Note um aumento significativo da corrente $\mathrm{I}_{\mathrm{h}}$ na presença do estímulo hipertônico quando comparado ao controle (-50,33 $\pm 0,9$ pA vos 20,1 \pm 7 pA, n=9), e um aumento adicional na corrente quando o L-NAME foi adicionado ao banho (-91.7 \pm 14 vos $-50,33 \pm$ $0,9)$. Diferenças estatísticas estão indicar por * $(* \mathrm{p}<0,05 ; * * \mathrm{p}<0,005)$. Não foi observado diferenças entre os fenótipos celulares 


\section{Lista de Tabelas}

Tabela 1. Controle positivo da pré-amplificação: Neurônios magnocelulares do SON foram préamplificados 2 vezes. Como mostrado, o fenótipo foi mantido, demonstrando que este procedimento não altera a proporção de RNAm dos neurônios .58

Tabela 2. Tripla caracterização de um único neurônio. A tabela mostra o fenótipo identificado por três métodos distintos: Eletrofisiologia, RT-qPCR e imunofluorescência em um único neurônio. Note a alta correlação entre o RT-qPCR e Imunofluorescência e a baixa correlação de ambos com a eletrofisiologia. * neurônios que expressaram somente um tipo de RNAm

Tabela 3. Expressão RNAm para isoformas dos canais HCN. Expressão dos canais HCN no supraóptico foi realizada por meio de single cell RT-qPCR. Neurônios vasopressinérgicos e ocitocinérgicos expressaram todas as isoformas, porém a do tipo 3 e 4 predominaram. Círculos coloridos indicam a expressão de uma determinada isoforma para cada célula analisada. Círculos Amarelos $=$ HCN1, Vermelhos $=$ HCN2, Verdes $=$ HCN3 e Azuis $=$ HCN4 .78 


\section{Sumário}

1. INTRODUÇÃO

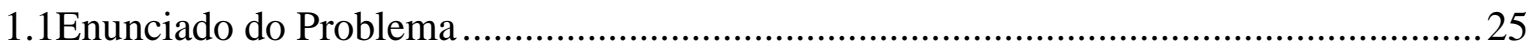

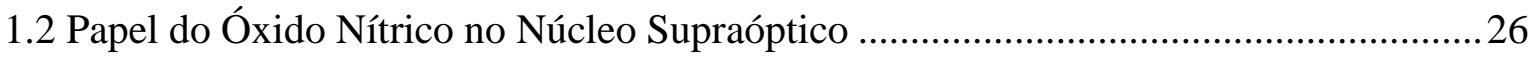

1.3 Óxido Nítrico e Vias de Sinalização: cGMP e S-Nitrosilação ......................................29

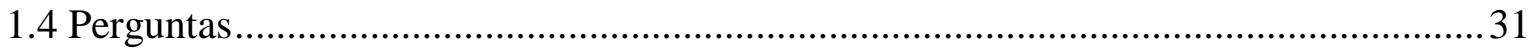

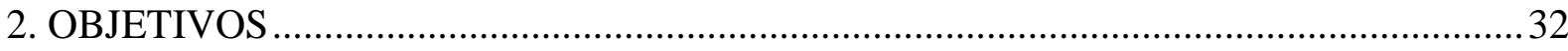

3. METODOLOGIA

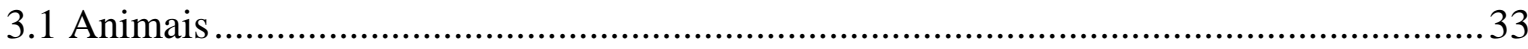

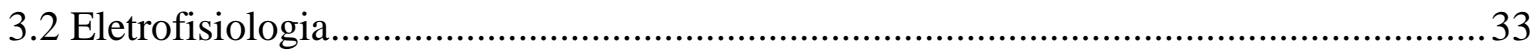

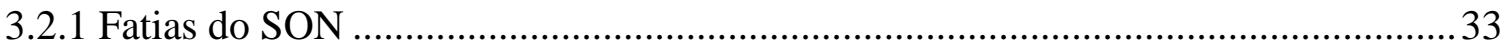

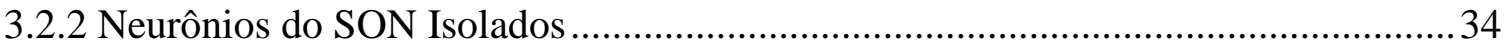

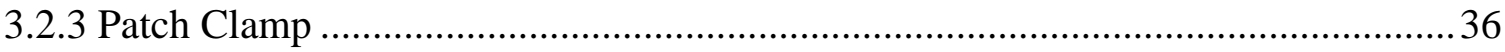

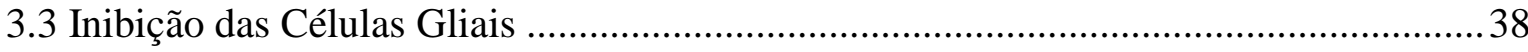

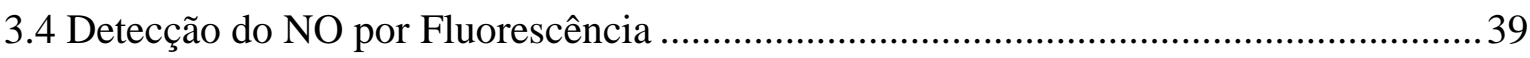

3.4.1 Imunofluorescência para Neurônios Isolados ......................................................... 40

3.5 Caracterização Fenotípica dos Neurônios do SON......................................................... 41

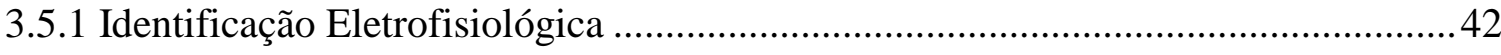

3.5.2 Obtenção de RNA Total de Células Únicas ........................................................... 42

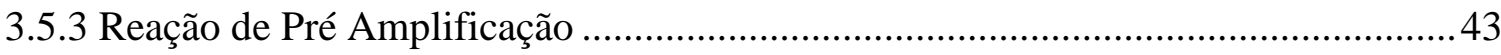

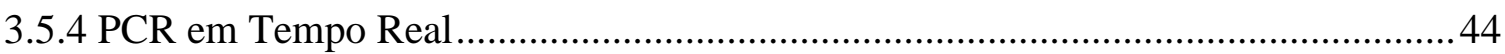

3.5.5 Eletrofisiologia, RT-qPCR e Imunofluorescência em um Único Neurônio.............. 45

3.6 Alterações do Equilíbrio Hidroeletrolítico e Fenótipo Celular.........................................46

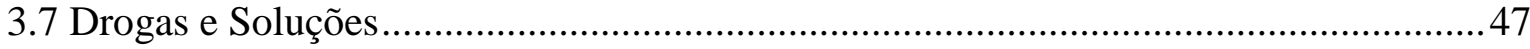

3.7.1 ACSF (Líquido Céfalo Raquidiano Artificial - Solução para Corte) ....................... 48 


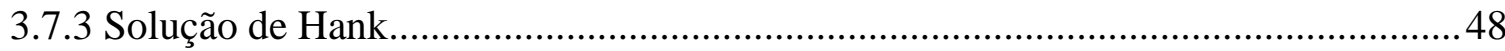

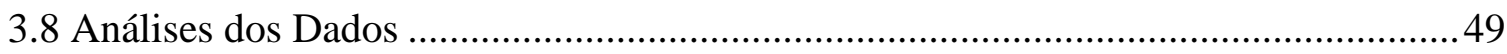

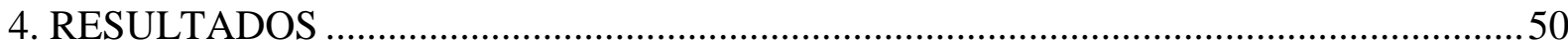

4.1 Envolvimento das Células Gliais na Modulação Nitrérgica do SON. ............................50

4.2 Caracterização Eletrofisiológica do Fenótipo dos Neurônios Magnocelulares ..............56

4.3 Correlações do Fenótipo Eletrofisiológico com Molecular ..........................................57

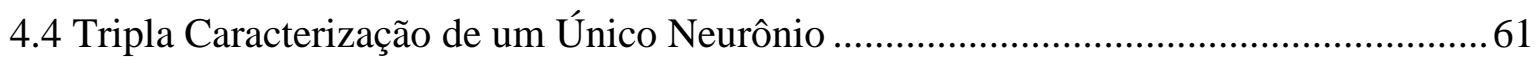

4.5 Caracterização Fenotípica de Neurônios Magnocelulares do Núcleo Paraventricular.. 64

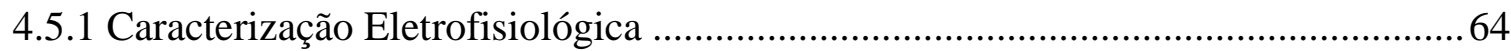

4.5.2 Caracterização Fenotípica do PVNmL pelo RT-qPCR ...........................................65

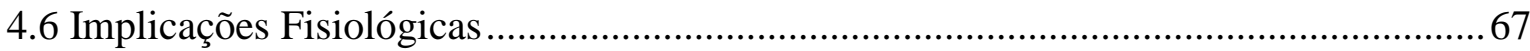

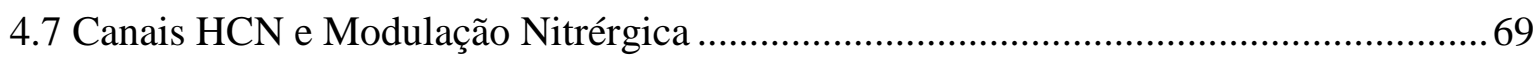

4.8 Neurônios Magnocelulares do SON Produzem NO ................................................. 71

4.9 Expressão dos Canais HCN por RT-qPCR Single Cell .............................................. 77

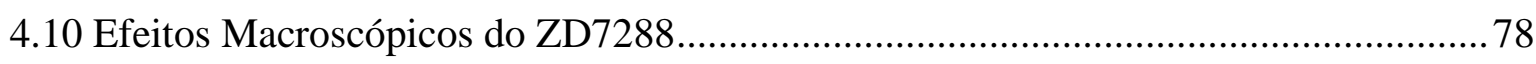

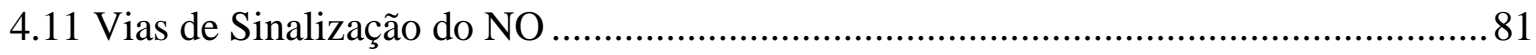

4.12 Óxido Nítrico Modula os Canais HCN por Mecanismo de S-nitrosilação................... 83

4.13 Modulações Nitrérgica dos Canais HCN Durante Estimulo Hipertônico Agudo ........85

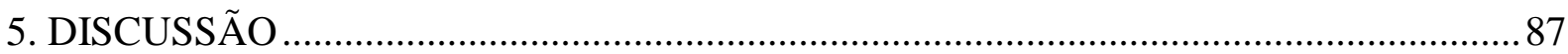

5.1 Caracterização Fenotípica Baseada no Método Eletrofisiológico ................................. 88

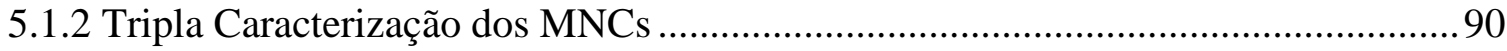

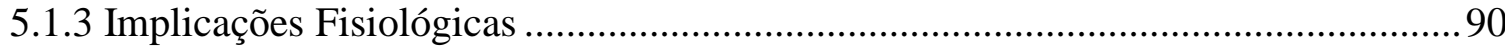

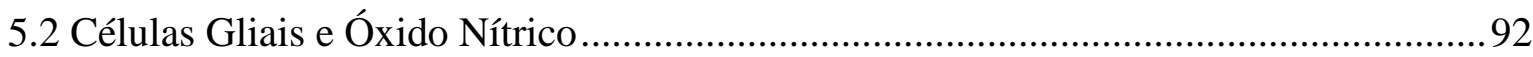


5.3 Origem do NO e Modulação dos Canais HCN …….........................................................96

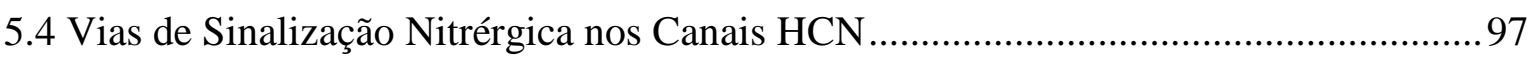

5.5 Modulação dos Canais HCN por S-nitrosilação ............................................................ 98

5.5 Modulação dos Canais HCN pelo NO Durante Estímulo Hipertônico ......................... 100

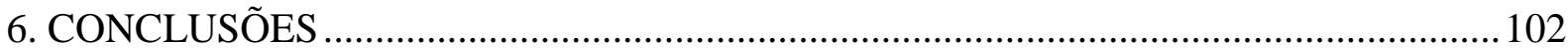

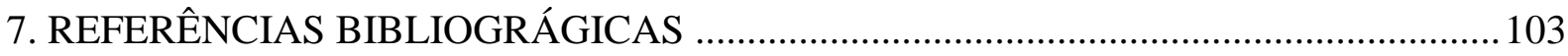

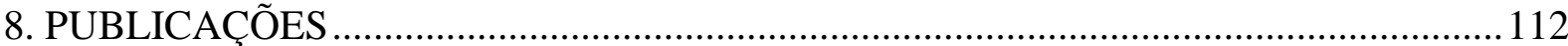




\section{INTRODUÇÃO}

\subsection{Enunciado do Problema}

Localizado bilateralmente ao quiasma óptico, o núcleo supraóptico (SON) integra informações provindas de áreas importantes envolvidas na regulação e manutenção da osmolalidade dos fluidos corporais (123). Tais informações, ou aferências, modulam a excitabilidade dos neurônios magnocelulares (MNCs) que por sua vez, controlam a secreção de ocitocina (OT) e vasopressina (VP) pela hipófise posterior (144). Em condições isotônicas, registros extracelulares dos $\mathrm{MNCs}$, in vivo, mostraram que esses neurônios exibem uma baixa frequência de disparo de potenciais de ação $(2-3 \mathrm{~Hz})$ resultando em uma liberação basal de VP e OT (118). Entretanto, registros eletrofisiológicos em ratos anestesiados e em preparações in vitro tem revelado que a excitabilidade desses neurônios muda em função da osmolalidade plasmática resultando em alterações na liberação dos neuropeptídios $(18,24$, 153). Tais evidências comprovam a participação do SON no equilíbrio hidroeletrolítico e evidenciam a importância de entender os mecanismos de controle dos MNCs.

A modulação da excitabilidade dos neurônios do SON é resultante da interação de múltiplas entradas sensoriais que incluem: osmorreceptores periféricos, osmorreceptores centrais, bem como a osmossensibilidade intrínseca dos MNCs per se (18). Os osmorreceptores periféricos encontram-se principalmente na vasculatura mesentérica do intestino delgado superior e na veia porta hepática $(9,29)$. Já em relação aos centrais, estes se localizam em núcleos constituídos por neurônios designados como osmorreceptores que se localizam fora da barreira hematoencefálica (órgãos circunventriculares - órgão vasculoso da lamina terminal, órgão subfornical e pré-óptica medial) e enviam projeções para os neurônios do SON e PVN $(5,17,65)$. Entretanto, embora estas conexões sinápticas sejam importantes para o controle da atividade dos neurônios do SON (65), estudos têm demonstrado que na sua 
ausência os MNCs são capazes de alterar sua excitabilidade em resposta ao estresse osmótico (107). Esta sensibilidade intrínseca, frente a alterações na osmolalidade, é resultado de uma despolarização (estímulo hipertônico) ou hiperpolarização (estímulo hipotônico) do potencial de membrana celular mediado por canais mecanosensíveis denominados de canais para cátions inativados por estiramento, cuja atividade é inversamente proporcional ao grau de distensão da membrana durante as alterações de volume celular $(15,105,108)$. Frente a estes resultados, os autores denominaram os neurônios do SON como osmosensíveis, ou seja, neurônios sensíveis a alterações de osmolalidade capazes de induzir respostas osmorregulatórias $(91$, 107). Todavia, a osmorregulação no sistema hipotálamoneurohipofiseal é um processo integrado, no qual a lesão de osmorreceptores centrais ou inativação dos canais mecanossensíveis nos MNCs resultam em respostas efetoras ineficientes. Assim, a convergência de múltiplas entradas sensoriais é responsável pelas respostas altamente elaboradas que resultam no reestabelecimento do equilíbrio hidroeletrolítico.

Embora a osmolalidade plasmática seja um dos principais fatores que promovem a ativação desses neurônios, vários neurotransmissores e neuropeptídios podem, direta ou indiretamente, controlá-los $(66,133)$, e o óxido nítrico tem sido foco de estudo nos últimos $\operatorname{anos}(129,141,147)$.

\subsection{Papel do Óxido Nítrico no Núcleo Supraóptico}

Durante as últimas décadas, o óxido nítrico (NO) tem sido apontado como uma molécula de sinalização fisiológica crítica nos tecidos dos mamíferos, em particular no sistema nervoso central (49). Sua descoberta como um neurotransmissor alterou radicalmente a maneira de se pensar a respeito da transmissão sináptica. O NO é um gás, cuja formação ocorre por meio da catálise enzimática promovida pela sintase do óxido nítrico (NOS). Esta 
enzima existe sob duas formas: constitutiva (NOSc) e induzida (NOSi). A NOSc é encontrada em duas isoformas, a neuronal (NOSn) e a endotelial (NOSe). A NOSn e NOSe, requerem a formação do complexo cálcio-calmodulina para sua ativação (75), enquanto que a NOSi, expressa em macrófagos, exerce sua atividade de maneira independente do cálcio mas estimulada por outras moléculas como citocinas (44). No entanto, todas as isoformas utilizam a L-arginina como substrato, que através de sua oxidação forma NO e citrulina (Figura 1), sendo este último reciclado em L-arginina para a formação de uma nova molécula de NO (27, 98) Em relação à expressão das enzimas que catalisam a formação do NO, a NOSn é abundantemente encontrada em várias regiões do SNC, tais como córtex, bulbo olfatório, núcleo acumbens, amígdala, hipocampo, tálamo, corpo trapezóide, magno da rafe, núcleo do trato solitário e cerebelo $(21,28)$. No hipotálamo estão presentes todas as isoformas, sendo a ordem de expressão NOSn > NOSe > NOSi (12). No SON a principal isoforma é a NOSn (150), sendo sua expressão gênica modulada por alterações na osmolalidade plasmática, ou seja, aumentos na osmolalidade induzem aumentos equivalentes na expressão gênica da enzima $(69,146)$. 


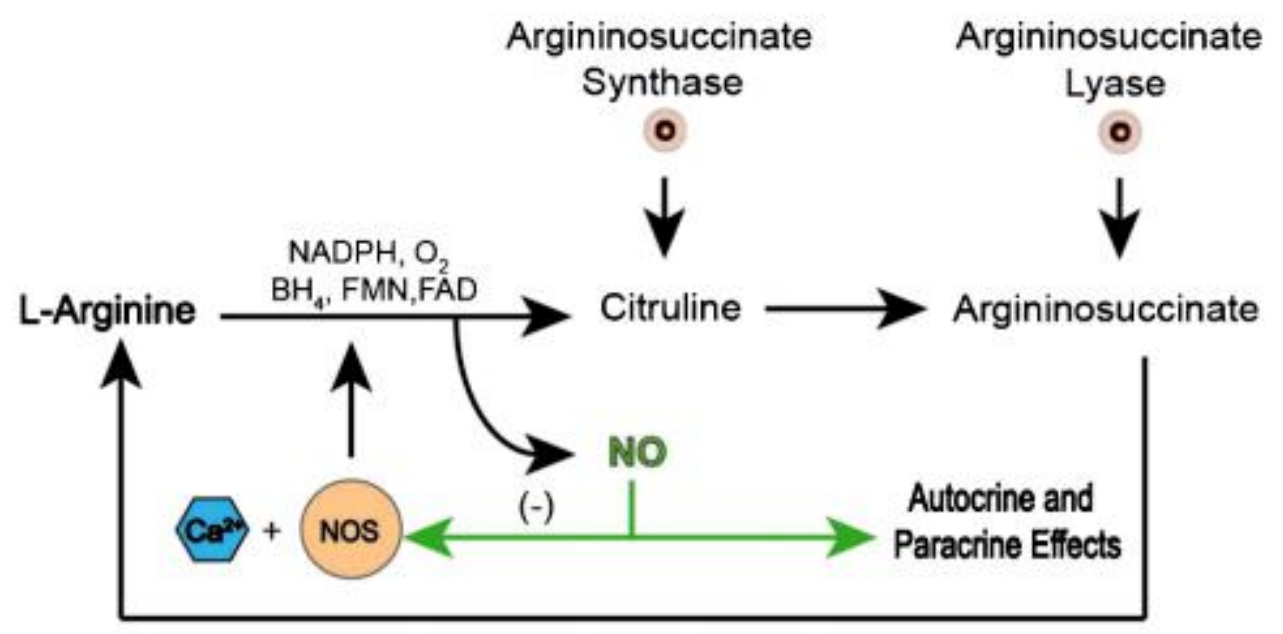

Figura 1. Síntese do Óxido Nítrico. Na presença de NADPH, oxigênio e alguns cofatores (tetrahidrobiopterina (BH4), Mononucleotídeo de Flavina (FMN), flavina adenina dinucleotídeo (FAD)) a sintase do óxido nítrico juntamente com o cálcio catalisa a reação transformando L-arginina em NO e citrulina. O NO uma vez formado, produzirá efeitos autócrinos e/ou parácrinos, bem como feedback negativo sobre a enzima NOS. Já a citrulina será convertida em arginina succinato, e Larginina pela ação da arginina succinato sintase e liase. (33).

Vários estudos têm demonstrado que o NO age como um neuromodulador da excitabilidade dos neurônios magnocelulares do SON, tanto em condições basais como durante alterações da tonicidade do meio extracelular (34, 35, 47, 67, 77). Até o momento, alguns mecanismos foram propostos na tentativa de explicar esta modulação. Dentre eles, estão a potenciação dos impulsos sinápticos GABAérgicos $(32,111,141)$, modulação de canais para potássio ativados por cálcio em condições isotônicas $(2,68)$ e modulação sobre canais ativados por hiperpolarização e nucleotídeo cíclico (HCN) (130). O NO também pode modular a atividade dos neurônios de modo independente de cGMP, seu principal segundo mensageiro (2).

Apesar de esses estudos terem demonstrado uma modulação nitrérgica nos neurônios magnocelulares do SON, a origem celular deste neuromodulador também não está clara. Recentemente vários trabalhos têm sugerido ainda, a participação das células gliais do 
hipotálamo no controle da osmolalidade $(104,109,112,116,131)$. Neurônios e astrócitos do SON estão em contato, e durante situações de hipertonicidade mostrou-se que os astrócitos são ativados minutos antes que os neurônios, evidenciando a capacidade dessas células de iniciarem processos osmorregulatórios no sistema nervoso central, em particular no núcleo supraóptico $(85,163)$. Além disso, como os astrócitos possuem toda maquinaria necessária para a produção de NO $(36,164)$, seria razoável pensar em uma modulação glial, de origem nitrérgica, sobre os neurônios desse núcleo.

\section{3 Óxido Nítrico e Vias de Sinalização: cGMP e S-Nitrosilação}

Já em relação às vias de sinalização utilizadas pelo NO, em algumas regiões do sistema nervoso central, a ativação da guanilato ciclase com consequente formação de cGMP está bem definida (49). Entretanto o uso desta via na modulação nitrérgica no SON ainda é controversa. Atualmente, essa visão clássica do cGMP como mediador exclusivo dos efeitos do NO tem sido revista, dada a capacidade deste mensageiro de interagir com proteínas por meio de ligações químicas. Essas interações influenciam vários processos celulares por alterarem a função de proteínas por meio de ligações reversíveis com grupamentos tióis de resíduos de cisteínas (60). A combinação do NO com a cisteína resulta em complexo mais estável, o S-nitrosothiol, que prolonga a atividade biológica do NO (3). Esse mecanismo é denominado de S-nitrosilação (Figura 2). 


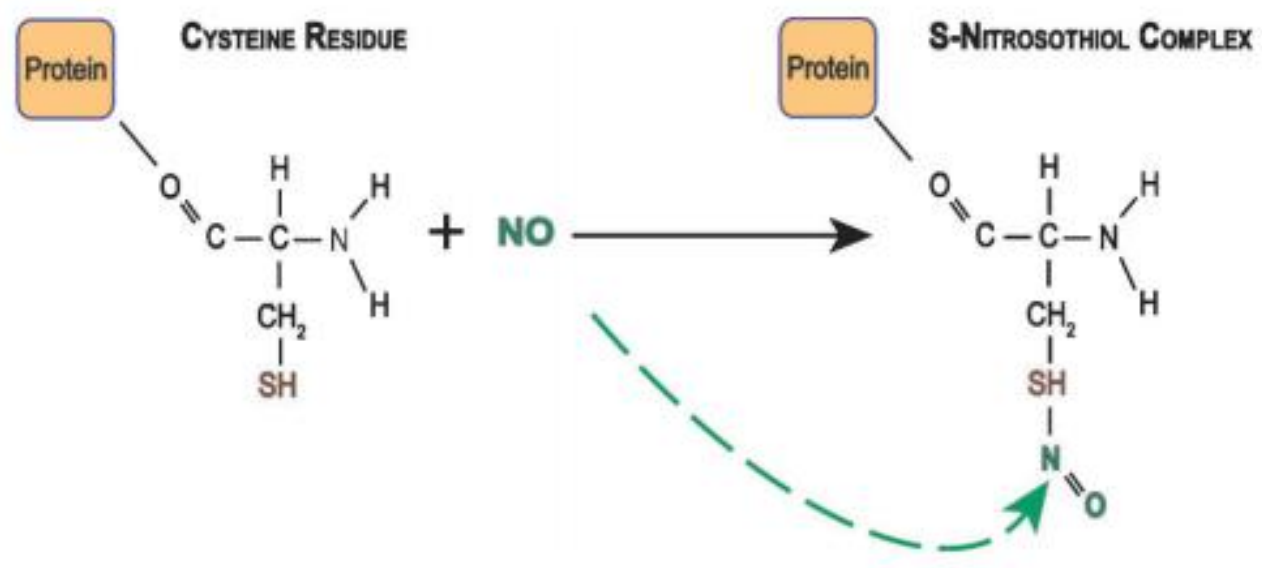

Figura 2. Esquema de s-nitrosilação de proteínas. Após ser sintetizado, o NO se liga a resíduos de cisteína da proteína resultando em um composto nitrosilado. Extraído de da Silva et al, 2014 (33).

A princípio, qualquer proteína que possua um grupamento tiol pode ser nitrosilada, porém estudos tem demonstrado certa especificidade. O NO não irá nitrosilar grupamentos tióis de baixo peso molecular, tais como cisteína e glutationa na ausência de oxigênio $\left(\mathrm{O}_{2}\right)$. Isso porque, a interação do NO com $\mathrm{O}_{2}$ elou ânions superoxido $\left(\mathrm{O}_{2}{ }^{-}\right)$resulta na produção de espécies reativas de oxigênio e nitrogênio, tais como, dióxido de nitrogênio $\left(\mathrm{NO}_{2}\right)$, trióxido de nitrogênio $\left(\mathrm{N}_{2} \mathrm{O}_{3}\right)$, e peroxinitrito $\left(\mathrm{ONOO}^{-}\right)$. $\mathrm{O} \mathrm{NO}_{2}$ e $\mathrm{ONOO}^{-}$são potentes oxidantes e podem atuar sobre resíduos de proteínas e lipídeos (121). Enquanto que o $\mathrm{N}_{2} \mathrm{O}_{3}$ é um oxidante mais leve e de preferência nitrosila aminas e tióis (157). Tem sido demonstrado que o NO pode utilizar esta via para modular proteínas de membrana incluindo canais iônicos $(3,25,30,79)$. Além disso, Wenker e colaboradores (155) demonstraram que os canais HCN são alvos da Snitrosilação endógena em motoneurônios, sugerindo uma via alternativa de sinalização do NO no SON. 


\subsection{Perguntas}

Dados do nosso laboratório têm demonstrado que o NO é capaz de modular a excitabilidade dos neurônios magnocelulares tanto em condições basais (147), quanto durante estímulos hipertônicos agudos (34) levando a uma inibição da atividade dessas células. Além disso, estas respostas ocorreram independentes das conexões sinápticas e envolveram a modulação de canais HCN (130). Entretanto, ainda é desconhecido à origem deste mensageiro neural, o envolvimento de outros tipos celulares nesta resposta, os mecanismos de sinalização utilizados pelo NO na modulação dos canais $\mathrm{HCN}$, se esta modulação difere em relação ao fenótipo celular e se ocorre em situações de estresse osmótico. Desta forma, considerando que: 1) os neurônios magnocelulares expressam a enzima para a síntese do NO em condições isotônicas e hipertônicas; 2) que os efeitos do NO parecem envolver, principalmente, a guanilato ciclase solúvel com consequente produção de cGMP; e 3) que os canais HCN possuem sítio de ligação para cGMP, nós hipotetizamos que os neurônios magnocelulares são capazes de produzir NO para gerar seu efeito inibitório na excitabilidade dos neurônios do SON não envolvendo outros tipos celulares neste processo, e que a modulação nitrérgica nos canais HCN envolve a produção de cGMP.

Diante do detalhado acima, as perguntas que surgiram foram: 1) Qual a origem do NO?; 2) Qual (is) molécula (s) poderia (m) estar atuando como segundos mensageiros na sinalização nitrérgica nos MNCs?; 3) Há envolvimento de outros tipos celulares, presentes no SON, nesta resposta?; 4) Como ocorre à modulação nitrérgica sobre os canais HCN? 5) O NO modula os canais HCN durante alterações das osmolalidade? 5) Há diferenças na modulação nitrérgica entre os fenótipos celulares? 


\section{OBJETIVOS}

Para responder as perguntas destacadas acima os objetivos deste trabalho foram:

1) Investigar o envolvimento das células gliais na modulação nitrérgica observada nos MNCs.

2) Desvendar a origem do NO.

3) Estudar as vias de sinalização da modulação nitrérgica sobre os canais HCN.

4) Avaliar mecanismos de s-nitrosilação.

5) Avaliar se NO modula os canais HCN durante estímulo hiperosmótico agudo.

6) Avaliar se há diferença na modulação nitrérgica nos MNCs em relação ao fenótipo celular.

Para tanto, realizamos experimentos de eletrofisiologia, para medidas de correntes iônicas e atividade neuronal intrínseca, e fluorescência para detecção da produção de NO desvendando assim sua origem, bem como experimentos de imunofluorescência para caracterização dos fenótipos celulares. 


\section{METODOLOGIA}

\subsection{Animais}

No presente estudo foram utilizados ratos Wistar, com idade entre 25 e 30 dias, provenientes do biotério central da Faculdade de Medicina de Ribeirão Preto/USP. Um dia antes dos experimentos os animais foram mantidos no Biotério do Departamento de Fisiologia, em caixas coletivas ( 3 animais por caixa), em temperatura de $23 \pm 2{ }^{\circ} \mathrm{C}$, sob regime de luz com ciclo claro-escuro de 12h ( $\operatorname{Luz}$ 7:00 - 19:00h). Todos os animais receberam água e ração à vontade, exceto para experimentos onde este parâmetro necessitou ser manipulado (ver abaixo).

Duas horas antes do experimento os animais foram levados ao laboratório e mantidos lá até a hora do início do mesmo, sem manipulação, a fim de minimizar o estresse. Todos os protocolos utilizados foram aprovados pelo comitê de ética de experimentação animal da Faculdade de Medicina de Ribeirão Preto - USP (023/2012).

\subsection{Eletrofisiologia}

Experimentos eletrofisiológicos tiveram como meta central avaliar a contribuição dos canais HCN para a excitabilidade dos MNCs, a participação das células gliais na modulação nitrérgica desses neurônios e dos canais $\mathrm{HCN}$, e os mecanismos de modulação do NO sobre estes canais. Para tanto, duas preparações distintas foram adotadas: fatias do SON e neurônios isolados em cultura.

\subsubsection{Fatias do SON}

Para obtenção das fatias hipotalâmicas contendo o SON procedeu-se como descrito abaixo. Após a decapitação dos animais com o auxílio de uma guilhotina, foi feita 
craniotomia na linha média da estrutura dorsal da caixa craniana utilizando-se uma pequena tesoura de pontas finas. O encéfalo foi rapidamente removido e transferido para um recipiente contendo solução de ACSF (Líquido cérebro espinhal artificial, ver soluções) próximo a $0{ }^{\circ} \mathrm{C}$, previamente equilibrado com mistura carbogênica $\left(95 \% \mathrm{O}_{2}-5 \% \mathrm{CO}_{2}\right)$. O tempo deste procedimento não excedeu 2 minutos, a fim de manter a integridade funcional do tecido. $\mathrm{O}$ encéfalo permaneceu submerso no ACSF durante 2 minutos. Em seguida, foi seccionado de modo a ter-se um bloco de tecido contendo o hipotálamo cuja base caudal foi colada (com cola de cianoacrilato) em um suporte de ágar a $4 \%$ em ACSF. A superfície dorsal deste bloco fica apoiada na porção vertical do suporte. Este, por sua vez, foi colado na plataforma acessória de um vibrátomo (modelo VT 1200 S, Leica, Bensheim, Alemanha) e o conjunto mergulhado em ACSF resfriado (próximo a $0{ }^{\circ} \mathrm{C}$ ), contido em câmara própria do aparelho. Após o posicionamento adequado da lâmina do vibrátomo ajustamos a frequência e a velocidade de corte, de modo a se obterem fatias viáveis com $230 \mu \mathrm{m}$ de espessura. Cada fatia, contendo o núcleo supraóptico, foi transferida a uma câmara contendo ACSF a $35^{\circ} \mathrm{C}$, borbulhado continuamente com mistura carbogênica, conforme descrito por Stuart e Sakmann (142). Três fatias de cada animal contendo os núcleos supraópticos foram mantidas na câmara de incubação durante um período de 30 a 60 minutos, e logo após foram utilizadas para os registros eletrofisiológicos.

\subsubsection{Neurônios do SON Isolados}

As vantagens de se utilizarem preparações com neurônios isolados são: 1) interromper a interação neurônio-glia e desta forma excluir a influência dessas células sobre a excitabilidade neuronal, e 2) a possibilidade de averiguar com maior precisão as ações do NO sobre a cinética dos canais HCN. 
Neste modelo experimental foram utilizados três ratos Wistar (25 - 30 dias) para dissociação mecânica dos neurônios. Após a remoção do encéfalo, (realizado da mesma forma que nos experimentos de eletrofisiologia, descritos acima) fatias de $230 \mu \mathrm{m}$ de espessura, contendo o SON, foram feitas e em seguida, transferidas para um recipiente com solução de Hank (especificada em soluções) constantemente borbulhada com oxigênio. As fatias permaneceram nesta solução por aproximadamente 60 minutos.

Após o período de incubação, pequenos blocos de tecido contendo a região do núcleo supraóptico foram transferidos para um recipiente com solução de Hank sem $\mathrm{Ca}^{+2}$ e $\mathrm{Mg}^{+}$ suplementada com tripsina ( $7 \mathrm{mg} / \mathrm{ml}$ - Sigma Chemical Corporation, St. Louis, MO, EUA) por um período de 30 minutos a $37{ }^{\circ} \mathrm{C}$. Após o tempo de digestão, os fragmentos foram lavados 3 vezes com Hank sem $\mathrm{Ca}^{+2}$ e $\mathrm{Mg}^{+}$e em seguida incubados em $2 \mathrm{ml}$ da mesma solução acrescida de 0,05\% de inibidor de tripsina (Sigma Chemical Corporation). Após a inibição enzimática, os fragmentos do núcleo supraóptico foram dissociados com o auxilio de três pipetas Pasteur de vidro, com diâmetros decrescentes. A solução foi novamente substituída por meio de cultura Neurobasal acrescido de 2\% de B27 (suplemento sem soro Life Technologies Corporation, Carlsbad, CA, EUA), 0,5 mM de glutamina e centrifugada a $1000 \mathrm{rpm}$ por $5 \mathrm{~min}$. O sobrenadante foi retirado, ressuspendido em $2 \mathrm{ml}$ de meio de cultura neurobasal suplementado com penicilina e estreptomicina (Sigma Chemical Corporation, St. Louis, MO, EUA) e semeado em lamínulas, previamente tratadas com poli L-lisina (Sigma Chemical Corporation,). Após 30 a 40 minutos, tempo necessário para que os neurônios possam aderir na lamínula, foi adicionado $2 \mathrm{ml}$ de meio Neurobasal e as placas foram incubadas em estufa a $37^{\circ} \mathrm{C}$, em atmosfera com $5 \%$ de $\mathrm{CO}_{2}$ e umidificada. Após 24 horas em cultura, $1 \mathrm{ml}$ de meio foi removido e foi adicionado neurobasal contendo $0,1 \mu \mathrm{M}$ de citosina arabinosídeo (ARA-C) para inibir o crescimento de células gliais. Os registros eletrofisiológicos foram feitos após 48 horas em cultura. 


\subsubsection{Patch Clamp}

A técnica de patch clamp no modo Whole cell, foi utilizada tanto para as fatias como para as células isoladas. As fatias ou neurônios isolados ficaram numa câmara de registro montada sobre a platina de um microscópio (Nikon E-600FN, Melville, New York). A mesma foi continuamente perfundida com ACSF saturado com mistura carbogênica, a um fluxo de 2 a $3 \mathrm{ml} / \mathrm{min}$. As fatias foram fixadas com uma pequena grade, construída com um aro de platina e fios de nylon para mantê-la imóvel no fundo da câmara e evitar seu deslocamento durante os registros.

Micropipetas com pontas entre 2-3 $\mu \mathrm{m}$ de diâmetro e resistências de 4-6 $\mathrm{M} \Omega$ (quando preenchidas com a solução de pipeta) foram fabricadas a partir de capilares de vidro borosilicato num estirador P-97 (Sutter Instrument Co.). As pontas das micropipetas foram polidas numa microforja (Narishige MF-83) com a intenção de se obter selos mais estáveis. A pipeta, uma vez preenchida com solução apropriada, foi fixada ao "probe" montado em um micromanipulador e conectada ao amplificador de patch modelo 200B (Molecular Devices Foster City, CA, EUA) através de um eletrodo de $\mathrm{Ag} / \mathrm{AgCl}$. Outro eletrodo de $\mathrm{Ag} / \mathrm{AgCl}$, imerso em solução aquosa de $\mathrm{KCl} 3 \mathrm{M}$ acrescentada de ágar a 2,5\% para aumento de viscosidade serviu como ponto de referência de potencial zero, conectando o banho à terra. As saídas de corrente e voltagem do amplificador estavam ligadas a um conversor A/D e D/A (Digidata 1440 - Molecular Devices - Foster City, CA, EUA) controlado por um microcomputador, para coleta e armazenagem dos dados em disco rígido. Os sinais de voltagem ou de corrente foram filtrados a $5 \mathrm{KHz}$ e digitalizados a $10 \mathrm{KHz}$. Tanto a aquisição quanto a análise dos sinais foram realizadas com auxílio de programas do pacote pClamp 10 (Molecular Devices - Foster City, CA, EUA). A placa digitalizadora também serviu para a 
geração e aplicação dos protocolos de pulsos de voltagem e de injeção de correntes inerentes a cada situação experimental.

Nas fatias, as células foram visualizadas com o auxílio de uma câmera (PCO Imaging; PCO sensicam qe) e um sistema de contraste de interferência diferencial (DIC). Os neurônios magnocelulares, por sua vez, foram inicialmente identificados de acordo com sua localização anatômica, dorso-lateralmente ao quiasma óptico (115), bem como pelos seus aspectos morfológicos (Figura 3). A micropipeta de vidro foi posicionada no núcleo supraóptico e o selo de alta resistência com a membrana celular foi alcançado em modo voltage clamp.

No modo current clamp a atividade intrínseca dos neurônios foi avaliada através de registros dos potenciais de membrana e no modo voltage clamp foram aplicados protocolos de voltagem previamente determinados e registradas as correntes macroscópicas.

Os registros eletrofisiológicos foram sempre feitos numa condição, controle para em seguida aplicar-se uma determinada droga ou alterarmos a osmolalidade do banho. As soluções perfundiram a câmara de registros por gravidade e todas as drogas foram aplicadas trocando-se a linha de perfusão. A saída do líquido de perfusão da câmara foi feita por meio de uma bomba de sucção. Bloqueadores sinápticos da transmissão glutamatérgica (DL-AP5 e CNQX) e GABAérgica (picrotoxina) foram utilizados durante todo tempo de registro e em todos os experimentos aqui demonstrados.

A ativação dos canais HCN foi feita no modo voltage clamp a partir da aplicação de pulsos de voltagem hiperpolarizantes entre $-50 \mathrm{mV}$ a $-135 \mathrm{mV}$ em passos de $-10 \mathrm{mV}$ e duração de 3 segundos cada pulso. Um pré-pulso condicionante foi fixado em $-50 \mathrm{mV}$. Já a análise de excitabilidade dos neurônios foi feita em current clamp com injeções de correntes de +50 pA a -40 pA e os registros foram utilizados tanto para a análise da excitabilidade 
neuronal (pulsos de corrente despolarizantes) como para análise da resistência de entrada (pulsos de corrente hiperpolarizantes, RI).

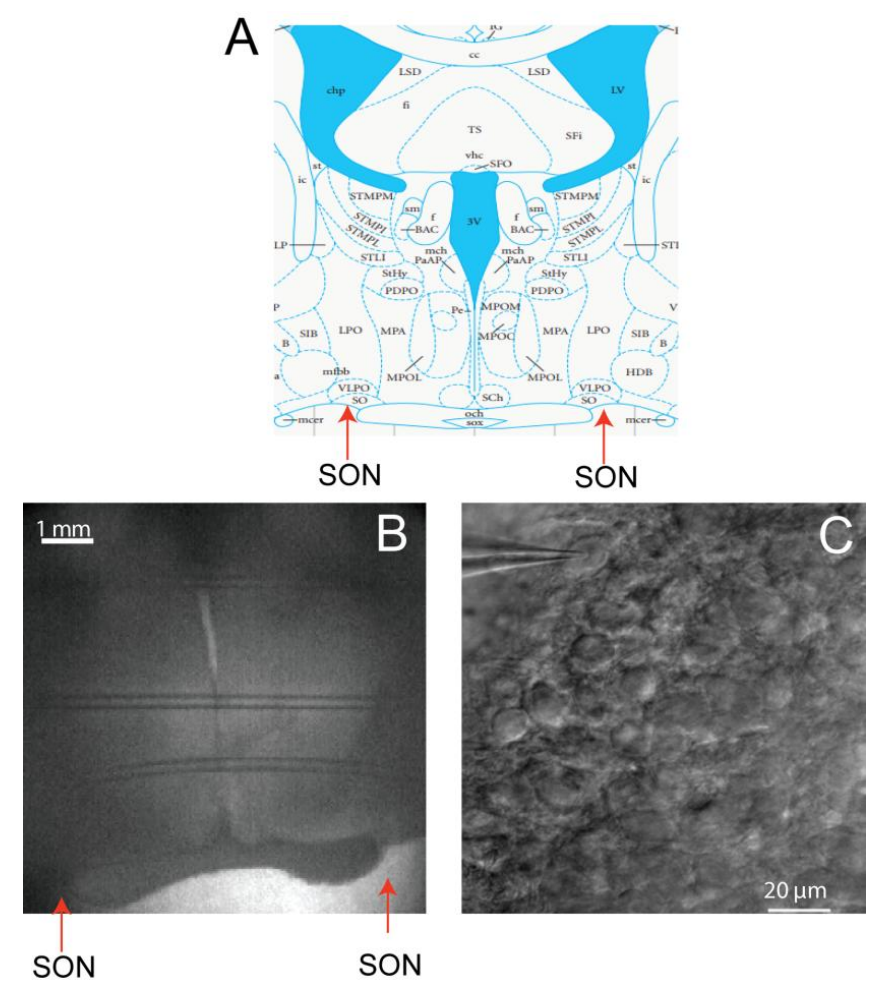

Figura 3. Fotomicrografias de fatias contendo o núcleo supraóptico. A) Em A, um esquema adaptado de Paxinos e Watson (115) mostrando a localização anatômica do SON (setas vermelhas), dorso-lateral ao quiasma óptico (och). Em B, uma fotomicrografia de uma fatia hipotalâmica de 230 $\mu \mathrm{m}$ de espessura, a seta em vermelho indica a localização do núcleo. Em $\mathbf{C}$, células visualizadas com o auxílio de um sistema de detecção de luz infravermelha. A micropipeta em contacto com uma célula estabelece a configuração Whole cell. SON - núcleo supraóptico.

\subsection{Inibição das Células Gliais}

Para os experimentos que visaram investigar a participação das células gliais nas respostas nitrérgicas, além de utilizarmos inibidores do metabolismo glial (Fluorocitrato de bário, Sigma Chemical Corporation, St. Louis, MO, EUA), nós também utilizamos a sobrecarga salina (ver detalhes abaixo). Em relação ao fluorocitrato, devido à presença do íon bário na sua composição, um protocolo para purificação foi utilizado seguindo o método 
descrito por Paulsen e colaboradores (114). Brevemente, o L- fluorocitrato de bário foi dissolvido em $1 \mathrm{ml}$ de $0,1 \mathrm{M} \mathrm{HCl}$ e duas a três gotas de $0,1 \mathrm{M}$ de $\mathrm{Na}_{2} \mathrm{SO}_{4}$ foram adicionadas para precipitar o íon $\mathrm{Ba}^{2}$. Em seguida, $2 \mathrm{ml}$ de $\mathrm{Na}_{2} \mathrm{PO}_{4} 0,1 \mathrm{M}$ de foi adicionado e a solução foi centrifugada a $1.000 \mathrm{xg}$ por $5 \mathrm{~min}$. O sobrenadante foi diluído em $\mathrm{NaCl} 0,9 \%$ para obter a concentração final, e o pH foi ajustado para 7,4. Neste protocolo as fatias foram incubadas em ACSF de registro (ver soluções) acrescido de $200 \mu \mathrm{M}$ de fluorocitrato por um período de 20 minutos antes de iniciar os registros eletrofisiológicos.

Em um segundo grupo de animais, a retração glial foi induzida através da sobrecarga salina que altera a relação morfológica e funcional entre neurônios e células gliais. Utilizada por vários pesquisadores $(53,58,127)$, a sobrecarga consistiu em desidratar o animal por 7 dias por meio da ingestão de $\mathrm{NaCl} 1,8 \%$ o que resulta em uma retração dos processos astrocíticos sobre os neurônios, alterando assim sua interação com os mesmos (126, 127). Neste modelo, os animais tiveram acesso somente ao $\mathrm{NaCl} 1,8 \%$, ao invés de água, e ração ad libitum. Desta forma foi possível analisar se com a retração glial há alguma alteração na modulação nitrérgica dos neurônios do SON.

\subsection{Detecção do NO por Fluorescência}

Com a finalidade de avaliar a produção de NO nos neurônios do SON, experimentos de fluorescência foram desenhados, visando detectar as alterações na sua atividade durante estresse osmótico. Os experimentos foram realizados em duas preparações distintas: cultura de neurônios e fatias do núcleo supraóptico. Para neurônios isolados, utilizamos um microscópio confocal multiusuário (TCS SP5, Leica, Heidelberg, Alemanha) da Faculdade de Medicina de Ribeirão Preto. Nos experimentos utilizando fatias do núcleo supraóptico, as alterações de fluorescência foram detectadas por meio de um microscópio epifluorescente (Nikon E-600FN, Melville, New York, EUA). Para ambas as situações, os neurônios 
magnocelulares do núcleo supraóptico foram carregados com um indicador fluorescente da produção de óxido nítrico, DAF-FM (Sigma Chemical Corporation, St. Louis, MO, EUA), durante 30 minutos (Figura 4). O indicador foi dissolvido em dimetil sulfóxido (DMSO) e 0,02 \% de ácido plurônico F127 em concentração estoque de $5 \mathrm{mM}$ e, então, diluído em solução de registro, a uma concentração final de $30 \mu \mathrm{M}$. A taxa de aquisição das imagens foi definida pela cinética do processo. Para o estresse osmótico foi utilizado solução de Hank (neurônios isolados) ou ACSF (fatias) acrescida de manitol com osmolalidade de 330 $\operatorname{mosm} /\left(\mathrm{Kg} \cdot \mathrm{H}_{2} \mathrm{O}\right)$. As imagens foram analisadas com o auxilio do software ImageJ (W.S. Rasband/National Institute of Heath, Bethesda, MD, EUA).
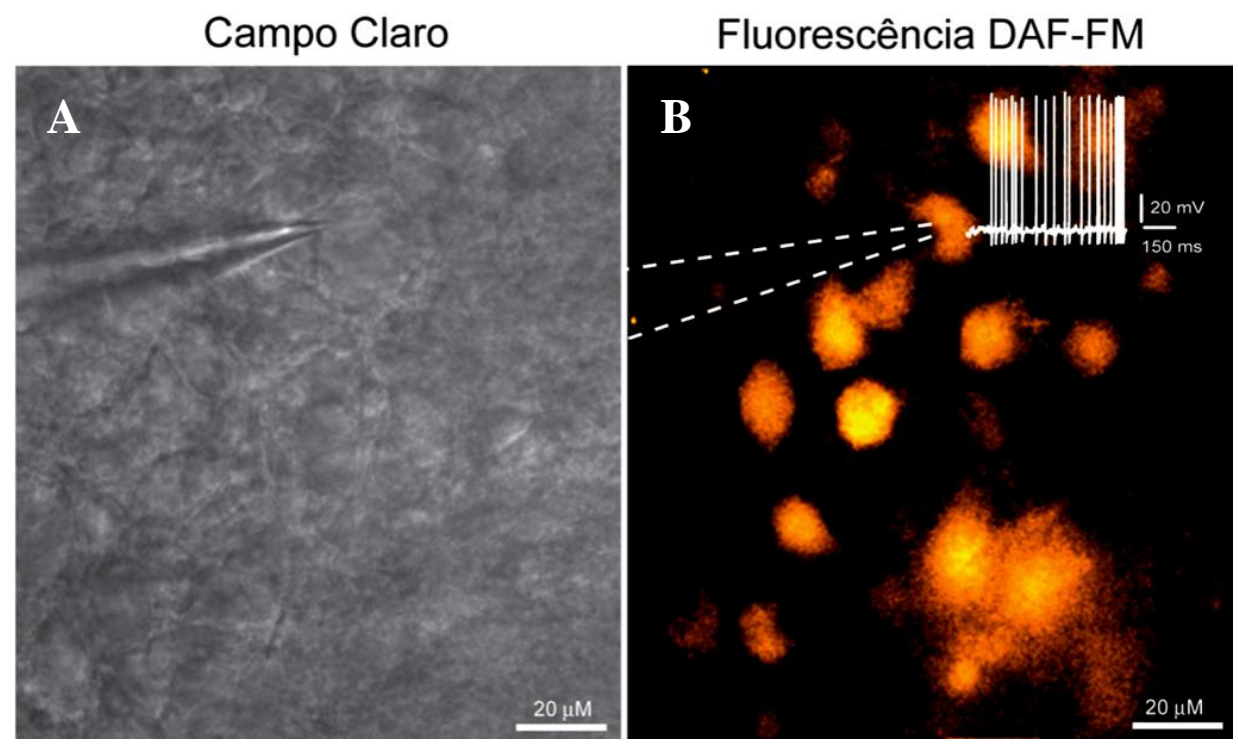

Figura 4. Marcação do NO pelo indicador DAF-FM. Imagens representativas de uma fatia do SON incubado com o indicador fluorescente da produção de NO, DAF-FM, visualizado em campo claro (A) e durante a excitação do indicador $(\mathbf{B})$. Linha tracejada em $\mathbf{B}$ representa a pipeta de vidro utilizada para registros de patch clamp. (DAF-FM: Excitação $=488 \mathrm{~nm}$; Emissão= $515 \mathrm{~nm}$ ).

\subsubsection{Imunofluorescência para Neurônios Isolados}

Devido à perda de morfologia dos neurônios magnocelulares em cultura, experimentos de fluorescência foram utilizados para identificação do fenótipo celular. Logo após o 
experimento de imunofluorescência para detecção da produção de NO, os neurônios isolados do SON foram fixados com paraformaldeído $4 \%$ por 30 minutos em temperatura ambiente, lavados 3x com PBS (tampão fosfato) por 5 min cada lavagem, permeabilizados com Triton X-100 0,25\% e incubados com albumina de soro bovino (BSA $10 \%$ ) durante 1 hora em câmara úmida. Após o período de bloqueio, as lamínulas foram incubadas durante a noite a 4 ${ }^{\circ} \mathrm{C}$ com anticorpo primário anti-OT (Rabbit, 1:500, Peninsula Laboratories, San Carlos, CA) e anti-VP (Guinea Pig anti-( $\left.\operatorname{Arg}^{8}\right)$-Vasopressin, 1:500, Peninsula Laboratories, San Carlos, CA) também em câmara umidificada. Em sequência, os neurônios foram incubados com anticorpo secundário Alexa flúor 488 e Cy5, ambos com diluição de 1:500 por 1 hora. As laminas foram montadas com prolong (Invitrogen Corporation, Carlsbad, CA, USP) e a fluorescência foi analisada em um microscópio confocal (TCS SP5, Leica, Bensheim, Alemanha). As imagens foram analisadas utilizando o software Image J (W.S. Rasband/National Institute of Heath, Bethesda, MD, EUA). A colocalização foi observada pela sobreposição das imagens, obtidas a cada $0.8 \mu \mathrm{m}$. Como experimento controle, algumas lamínulas foram incubadas somente com anticorpo secundário e um marcador nuclear (DAPI).

\subsection{Caracterização Fenotípica dos Neurônios do SON}

Como já foi demonstrado que neurônios vasopressinérgicos e ocitocinérgicos do SON podem responder de maneira diferente a uma mesma situação experimental (153), caracterizar os diferentes fenótipos torna-se de suma importância. Assim, para diferenciá-los utilizamos três ferramentas: Eletrofisiologia, técnica de reação da transcriptase reversa em tempo real (PCR) e a imunofluorescência do neurônio registrado. 


\subsubsection{Identificação Eletrofisiológica}

O fenótipo dos neurônios magnocelulares foi eletrofisiológicamente identificado em função da presença ou ausência de correntes retificadoras. Este protocolo foi previamente descrito por Armstrong e Stern $(7,8,139)$ baseado em suas observações de que durante injeções de corrente negativa a relação Voltagem x Corrente era linear em neurônios vasopressinérgicos e não linear em neurônios ocitocinérgicos. De acordo com os autores, isto é devido ao fato de que os neurônios OT expressam uma corrente de potássio retificadora sustentada para fora (SOR), a qual é ativada com a aplicação de corrente negativa. Apesar de o protocolo ter sido descrito utilizando microeletrodos intracelulares, recentemente, outros autores validaram o fato de que esta distinção entre os fenótipos pode também ser feita com patch-clamp no modo Voltage Clamp $(61,165)$. Estes autores, na verdade, além de correlacionar a presença ou ausência da corrente retificadora para fora sustentada (SOR) com o fenótipo VP ou OT, também atribuíram a neurônios OT a existência de uma retificação para dentro induzida pela hiperpolarização (IR). Assim, no presente trabalho, a distinção eletrofisiológica entre os fenótipos foi feita utilizando-se o protocolo descrito por aqueles autores em Voltage Clamp. Este consistiu na aplicação, por $250 \mathrm{~ms}$, de pulsos de voltagem de $-40 \mathrm{mV}$ a $-135 \mathrm{mV}$ (em passos de $-10 \mathrm{mV}$ ) a partir de um pulso condicionante no qual a célula é mantida a $-40 \mathrm{mV}$ por $100 \mathrm{~ms}$. Por fim, uma relação $I-V$ das respostas obtidas foi feita utilizando-se o valor estacionário da corrente nos $10 \mathrm{~ms}$ finais dos pulsos. Assim, baseado em Hirasawa e cols. (61) e Zampronio e cols. (165) assumiu-se neste trabalho que neurônios VP apresentam a relação $I-V$ linear, ao passo que esta relação para neurônios OT é não linear.

\subsubsection{Obtenção de RNA Total de Células Únicas}

Com o intuito de validar o protocolo eletrofisiológico para distinção dos fenótipos em Whole cell, após realizar o registro, o citoplasma do neurônio foi sugado para o interior da 
micropipeta e submetido à análise quantitativa da expressão dos RNAms da vasopressina e ocitocina, para determinar o fenótipo molecular da célula registrada. Como notado por Sucher e Deitcher (143), mesmo em culturas celulares a sucção de uma célula inteira para dentro das pipetas utilizadas em patch-clamp é rara. No entanto, a simples difusão do conteúdo citoplasmático da célula registrada, devido à diluição da solução de pipeta durante o registro, já permite que se tenha RNAm suficiente para que o material seja submetido à transcrição reversa. Desta forma, após a sucção do conteúdo celular o material passou pela transcrição reversa, que consiste na síntese de DNA complementar (cDNA) a partir de um molde RNAm. Esta reação foi realizada em um termociclador Mastercycler Gradient (Eppendorf, Hamburg, Alemanha) utilizando-se um kit próprio para a transcrição reversa com hexanucleotídeos randômicos (High Capacity cDNA Reverse Transcription Kit, Life Technologies Corporation, Carlsbad, EUA), e seguindo o protocolo recomendado pelo fabricante.

\subsubsection{Reação de Pré Amplificação}

Uma vez que a quantidade de cDNA obtida a partir de uma única célula é muito pequena, fez-se necessário a realização de uma Pré-Amplificação do cDNA obtido a partir da RT. Após a conversão do RNAm para cDNA, o material foi submetido a uma préamplificação. Para tal, utilizamos um kit destinado a esta finalidade (TaqMan PreAmp Master Mix Kit, Life Technologies Corporation, Carlsbad, EUA) e as seguintes sondas de hidrólise TaqMan: Rn00564446_gl (vasopressina), Rn00566449_ml (ocitocina) e NM_031144.2 (BActina; gene de referência, controle positivo das reações). A reação foi executada em um termociclador Mastercycler Gradient (Eppendorf, Hamburg, Alemanha) seguindo, novamente, as recomendações fornecidas pelo fabricante do kit para 14 ciclos de reação. Após a pré-amplificação, foi feita uma quantificação do cDNA para cada amostra, utilizando-se o espectrofotômetro NanoDrop 1000 (Thermo Scientific, Wilmington, EUA). A concentração de cDNA obtida indicou se havia, na amostra, material suficiente para realização do PCR em 
tempo real (qPCR), assim como a pureza da amostra. Para experimentos da análise da expressão de canais $\mathrm{HCN}$ no $\mathrm{SON}$ as seguintes sondas foram utilizadas: $\mathrm{HCN}-1$ Rn00670384_m1, HCN-2 Rn01408572_mh, HCN3 Rn00586666_m1, HCN4 Rn00572232_m1 e os mesmos procedimentos descritos anteriormente foram seguidos.

\subsubsection{PCR em Tempo Real}

A reação de qPCR foi realizada em um termociclador com detector de fluorescência modelo StepOnePlus (Life Technologies Corporation, Carlsbad, EUA) com suporte a placas de 96 poços de reação. Cada reação foi feita em singleplex e em triplicata, sendo utilizadas as mesmas sondas hidrolíticas mencionadas anteriormente e o kit para PCR TaqMan Universal PCR Master Mix (Life Technologies Corporation, Carlsbad, EUA).

\subsubsection{Análises dos Resultados RT-qPCR}

Para análise dos resultados obtidos pelo RT-qPCR nós utilizamos os mesmos critérios previamente descritos pelo nosso grupo (93). Assim, a quantificação da expressão relativa dos dois genes, OT e VP, respectivamente, foi feita baseada nos seguintes princípios: 1) que a quantidade de amostra em um dado ciclo é uma função da quantidade inicial de material multiplicada pela eficiência de amplificação elevada ao número de ciclos realizados (59):

$$
X_{A, n}=X_{A, o} \times\left(1+E_{A}\right)^{n} \quad \text { Equação 1, }
$$

onde: $X_{A, n}$ é o número de moléculas-alvo no ciclo n; $X_{A, o}$ é o número inicial de moléculasalvo; $E_{A}$ é a eficiência de amplificação do alvo; e $n$ é o número do ciclo; e (2) que a quantidade de moléculas dos genes-alvo é igual ao seu ciclo de quantificação (Cq), ou seja:

$$
X_{A V P, C q}=X_{O T, C q} \quad \text { Equação 2, }
$$


onde: $X_{A V P, C q}$ e $X_{O T, C q}$ são a quantidade de moléculas de vasopressina e ocitocina, respectivamente, no ciclo de quantificação $C q$.

A partir das equações 2 e 3 , tem-se que:

$$
\frac{X_{A V P, O}}{X_{O T, O}}=\frac{\left(1+E_{O T}\right)^{C q} O T}{\left(1+E_{A V P}\right)^{C q_{A V P}}} \quad \text { Equação. 3, }
$$

onde a razão $\frac{X_{A V P, O}}{X_{O T, O}}$ expressa à quantidade inicial de cDNA de vasopressina pela quantidade inicial de cDNA de ocitocina.

Assim, neurônios que apresentaram razões maiores que 1 foram considerados como vasopressinérgicos e menores que 1 como ocitocinérgicos. Razões iguais ou próximas a 1 foram consideradas como neurônios com características intermediárias na qual o cDNA para VP e OT são expressos em quantidades similares.

\subsubsection{Eletrofisiologia, RT-qPCR e Imunofluorescência em um Único Neurônio.}

Para evitar erros sobre a expressão de cDNA e sua correlação com o peptídeo produzido, nós realizamos uma tripla caracterização utilizando a eletrofisiologia, o RT-qPCR e também a imunofluorescência em um único neurônio. Para tanto $0,2 \%$ de biocitina, um traçador intracelular (Life Technologies Corporation, Carlsbad, EUA), foi acrescentado à solução de pipeta, utilizada para os registros eletrofisiológicos. Desta forma, um novo grupo de neurônios foi registrado utilizando o protocolo eletrofisiológico e subsequente a este o citoplasma da célula, diluído na solução de pipeta, foi coletado para procedimentos de transcrição reversa e qPCR (Para maiores detalhes ver seção 3.5.2). Em seguida a fatia foi fixada em paraformaldeído (PFA; 4\%) durante 12 horas e desidratadas em sacarose $30 \%$ durante o mesmo período de tempo. Após a desidratação, as fatias foram transferidas para uma solução criopretetora (0,1 M PBS: 0,3\% de etileno glicol, 0,2\% de glicerol, v/v) a $-20{ }^{\circ} \mathrm{C}$ 
até serem imunohistoquímicamente processadas. Para o processamento da imunofluorescência, os cortes foram bloqueados e permeabilizados em PBS contendo $10 \%$ de soro de cavalo e $0,1 \%$ de Triton, durante 1 hora à temperatura ambiente. Em seguida, as fatias foram incubadas durante a noite a $4{ }^{\circ} \mathrm{C}$ com anticorpos primários: anti-VP (1:1000 Guinea Pig anti-( $\left.\operatorname{Arg}^{8}\right)$-Vasopressin, Peninsula Laboratories, San Carlos, CA) e anti-OT (1:1000 Rabbit, Peninsula Laboratories, San Carlos, CA). Subsequentemente, as fatias foram lavadas com PBS 0,01 M e incubadas com os anticorpos secundários: anti guinea pig Cy5 para VP e anti rabbit Alexa 488 para OT por 1 hora (1:500). Ao mesmo tempo, os neurônios marcados com biocitina foram revelados por reação com estreptavidina (Alexa Flúor 405 conjugado, Life Technologies Corporation, Carlsbad, CA, EUA), diluída a 1:500. As fatias foram então lavadas três vezes em PBS e montadas em lâminas de vidro com Fluoromount (Sigma Chemical Corporation, St. Louis, MO, EUA). Imagens de fluorescência foram adquiridas sequencialmente (intervalo de $0,3 \mu \mathrm{m}$ ) em um microscópio confocal (TCS SP5, Leica, Bensheim, Alemanha), e as análises foram feitas utilizando o software ImageJ (W.S. Rasband/National Institute of Heath, EUA - http://rsb.info.nih.gov/ij). Para cada fatia, o neurônio positivo para biocitina foi identificado e projeções em $\mathrm{z}$ foram coletadas sequencialmente para analisar a colocalização.

\subsection{Alterações do Equilíbrio Hidroeletrolítico e Fenótipo Celular}

Com o intuído de investigar se há alterações na proporção de neurônios magnocelulares OT e VP durante desafios fisiológicos, ratos Wistar (25 e 30 dias), foram divididos em três grupos experimentais: controle, restrição hídrica, e ratos submetidos à sobrecarga salina (n = 4 por grupo). No grupo controle, os animais tiveram água ad libitum durante 7 dias, enquanto que no modelo de restrição hídrica, os animais tiveram acesso apenas a 30\% do volume de água ingerida pelos animais do grupo controle, sendo que a água era oferecida no início da fase escura do ciclo. Já no modelo de sobrecarga salina, os animais tiveram acesso apenas a 
solução de $\mathrm{NaCl}$ 1,8\% ad libitum por 7 dias. Todos os grupos tiveram livre acesso a ração. No sétimo dia, os animais foram anestesiados (tribromoetanol: $250 \mathrm{mg} . \mathrm{kg}$ - 1, ip; Sigma Chemical Corporation, St. Louis, MO, EUA), e perfundidos com PBS 0,1 M, seguido por 4\% de paraformaldeído. Fatias contendo o SON $(30 \mu \mathrm{m}$ de espessura) foram feitas por auxilio de um criostato HM 505 N (Microm, Charleston - EUA) e armazenadas numa solução crioprotetora (0,1 M PBS: 0,3\% de etileno glicol, 0,2\% de glicerol, v/v) a $-20{ }^{\circ} \mathrm{C}$ até serem imunohistoquimicamente processadas. A imunofluorescência foi realizada utilizando-se os mesmos métodos descritos anteriormente (seção 2.5.5) e as imagens foram obtidas sequencialmente $(0,3 \mu \mathrm{m}$ por imagem) a partir de seis secções mediais do SON, de cada rato, em um microscópio confocal (TCS SP5, Leica, Bensheim, Alemanha). Após as aquisições os neurônios VP e OT imunorreativos foram contados bilateralmente sem conhecimento, pelo experimentador, da origem da fatia (se controle, ratos com sobrecarga salina ou restrição hídrica), com o auxilio do software Imagem J - Cell Counter Plugin. Os resultados foram representados como média \pm epm, e a proporção de cada fenótipo encontrado em cada condição experimental (controle, restrição hídrica, e sobrecarga salina), foram comparados com ratos controle pelo teste estatístico ANOVA One-way e pós-teste de Bonferroni (Prism 5

- GraphPad Software, Inc., La Jolla, CA, EUA). Valores de p menores que 0,05 foram considerados significativos.

\subsection{Drogas e Soluções}

As drogas utilizadas neste trabalho foram as seguintes: L-NAME $\left(\mathrm{N}^{\omega}\right.$-nitro-L-arginine methyl éster), inibidor não seletivo da NOS $100 \mu \mathrm{M}$; L-arginina, substrato para NOS (500 $\mu \mathrm{M})$; CNQX (6-cyano-7-nitroquinoxaline-2,3-dione), antagonista competitivo para receptores AMPA $(10 \mu \mathrm{M})$; DL-AP5 (DL-2-Amino-5-phosphonovaleric acid) um antagonista de receptores NMDA $(30 \mu \mathrm{M})$, picrotoxina um bloqueador de GABAa $(30 \mu \mathrm{M}) ; 30 \mu \mathrm{M}$; ZD7288 um agente bradicárdico que age como bloqueador para $\mathrm{I}_{\mathrm{h}}(50 \mu \mathrm{M})$; tetraetilamonio 
(TEA) e 4-aminopiridina (4AP), bloqueadores de canais para $\mathrm{K}$ (ambos a $1 \mathrm{mM}$ ). ODQ inibidor da guanilato ciclase solúvel $(30 \mu \mathrm{M})$, Fluorocitrato de bário, um inibidor do metabolismo glial $(200 \mu \mathrm{M})$, SIN 1 doador de NO $(100 \mu \mathrm{M})$. Todas as drogas foram obtidas da Sigma Chemical Co (Saint Louis, MO, EUA).

\subsubsection{ACSF (Líquido Céfalo Raquidiano Artificial - Solução para Corte)}

A solução de ACSF utilizada nos procedimentos de obtenção das fatias teve a seguinte composição (em mM): $\mathrm{NaCl} 121 ; \mathrm{KCl} 3 ; \mathrm{CaCl}_{2} 2 ; \mathrm{MgCl}_{2} 1,3 ; \mathrm{NaHCO}_{3} 26$ e glicose 25. A osmolalidade da solução ficou entre 305 - 311 mosm $/ \mathrm{Kg} \cdot \mathrm{H}_{2} \mathrm{O}$ e o pH de 7,4 quando equilibrada com mistura carbogênica $\left(5 \% \mathrm{CO}_{2}\right.$ e $95 \%$ de $\left.\mathrm{O}_{2}\right)$.

\subsubsection{ACSF Registro}

A solução de ACSF, utilizada nos procedimentos de manutenção e superfusão das fatias, tem a seguinte composição (em mM): $\mathrm{NaCl} 121 ; \mathrm{KCl} 4 ; \mathrm{CaCl}_{2}$ 2,5, $\mathrm{MgCl}_{2}$ 1,3, $\mathrm{NaHCO}_{3}$ 26; e glicose 10. A osmolalidade desta solução ficou entre 295 - $300 \mathrm{mosm} / \mathrm{Kg} \cdot \mathrm{H}_{2} \mathrm{O}$ e pH de 7,4 quando equilibrada com mistura carbogênica. A solução hipertônica foi obtida adicionando manitol ao ACSF de registro para obter osmolalidade de 330 mosm/Kg. $\mathrm{H}_{2} \mathrm{O}$.

\subsubsection{Solução de Hank}

A solução utilizada nos experimentos com neurônios isolados teve a seguinte composição (em mM): $\mathrm{NaCl} 140 ; \mathrm{KCl} 4,6 ; \mathrm{CaCl}_{2}$ 1,3; $\mathrm{MgCl}_{2}$ 1,6; $\mathrm{NaHCO}_{3}$ 5; HEPES 10; glicose 10. A osmolalidade ficou entre 300 a 310 mosm $/ \mathrm{Kg}_{\mathrm{H}} \mathrm{H}_{2} \mathrm{O}$ e $\mathrm{pH}$ de 7,4 quando corrigido com $\mathrm{NaOH}$.

As demais soluções empregadas foram desenhadas a partir da necessidade de cada experimento. O mesmo raciocínio aplica-se as drogas que foram utilizadas, sejam bloqueadores de vias/canais específicos ou indicadores fluorescentes. 


\subsection{Análises dos Dados}

A análise dos dados foi realizada com o auxilio do pacote de programas do pClamp10 (Axon Instruments, Sunnyvale, CA - EUA), Mini Analysis 4.3.2 (Synaptosoft, Fort Lee - NJ), OriginPro 8 (OriginLab Corporation, Northampton, MA - EUA) e Prism 5 (Graphpad software, Inc.,La Jolla, CA).

Para isolamento das correntes $\mathrm{I}_{\mathrm{h}}$, foi necessário utilizar um método de subtração, já descrito por outros (51), devido ao fato de que $\mathrm{I}_{\mathrm{h}}$ não é a única corrente ativada pelo protocolo aplicado. Assim, foi feita uma subtração da corrente registrada durante o controle daquela registrada com o bloqueador (ZD7288), resultando somente da corrente $\mathrm{I}_{\mathrm{h}}$. O mesmo raciocínio foi utilizado para obtenção da corrente $\mathrm{I}_{\mathrm{h}}$ na presença de outros moduladores.

A significância estatística da diferença entre os grupos experimentais foi testada utilizando-se teste t pareado ou não pareado de acordo com cada condição experimental, e valores de $\mathrm{p}<0,05$ foram considerados como significativos. Os valores foram expressos como médias \pm erro padrão das médias. 


\section{RESULTADOS}

\subsection{Envolvimento das Células Gliais na Modulação Nitrérgica do SON.}

Para avaliarmos a participação das células gliais na modulação nitrérgica observada no SON, nós escolhemos alguns protocolos experimentais que minimizasse a ação destas células na atividade dos neurônios magnocelulares e avaliamos se a modulação nitrérgica ainda estava presente (ver metodologia para maiores detalhes seção 3.2.1 e 3.2.2).

No primeiro utilizamos um inibidor do metabolismo glial (fluorocitrate $200 \mu \mathrm{M}$ ) por 20 min e em seguida a atividade intrínseca dos neurônios (na presença de bloqueadores glutamatérgicos e GABAérgicos) foi registrada e considerada como condição controle. Após 10 minutos de registro controle o substrato da formação do NO, L-arginina $(500 \mu \mathrm{M})$ foi adicionada a solução de banho. Como podemos observar na figura 5, não houve diferença significativa na frequência de disparo entre os grupos de neurônios sugerindo que estas células não interferem na modulação nitrérgica observada no SON. 


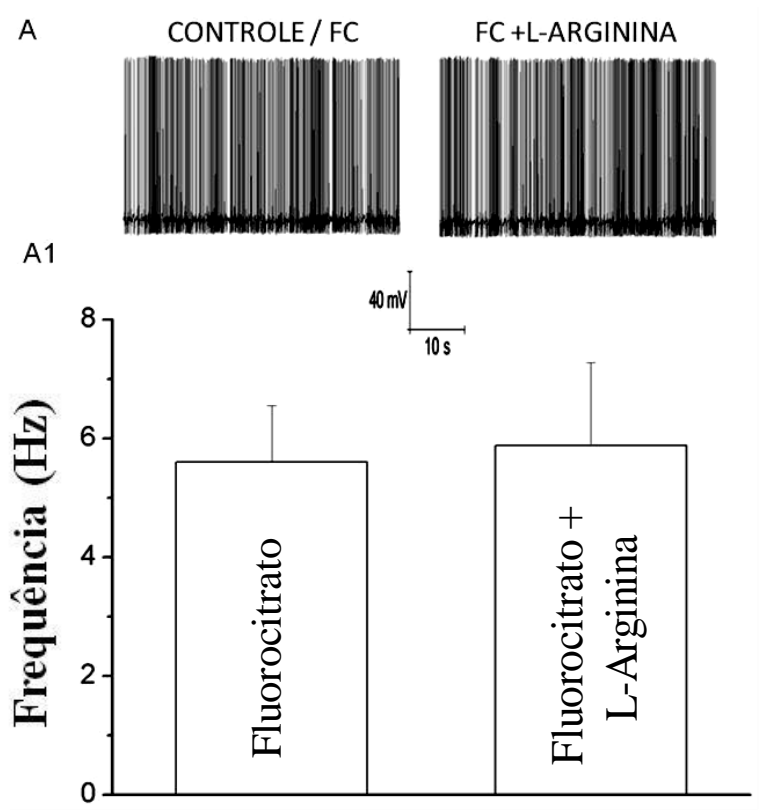

Figura 5. Efeitos do inibidor do metabolismo glial na modulação nitrérgica dos neurônios magnocelulares do SON. A mostra traçados típicos da atividade intrínseca (registros feitos na presença de bloqueadores sinápticos - picrotoxina, CNQX e DL-AP5), de um dos neurônios do grupo, analisados após a incubação com o bloqueador do metabolismo glial fluorocitrato e com o substrato do NO, L-arginina $(500 \mu \mathrm{M})$. Em A1 tem-se as médias da frequência de disparo de potenciais de ação dos neurônios analisados ( $\mathrm{n}=7)$. Não houve diferença estatística entre os grupos $(5,6 \pm 0,9 \mathrm{~Hz}$ x 5,8 $\pm 1,4$ $\mathrm{Hz} ; \mathrm{p}>0,05)$. A análise da frequência foi realizada utilizando 1 min de registro de cada condição experimental.

Devido às criticas ao uso do fluorocitrato e seu efeito em canais iônicos por resíduos de bário que podem permanecer na solução durante o processo de purificação, nós optamos por utilizar sobrecarga salina. Desta forma, após 7 dias a atividade intrínseca dos neurônios foram registradas na presença do substrato para a formação do NO, L-arginina, ou na presença do inibidor da sintase do óxido nítrico, L-NAME.

Como mostrado na figura 6, obtivemos dois resultados distintos na presença de Larginina. De 11 neurônios registrados 7 apresentaram uma redução na frequência de potenciais de ação $(4,7 \pm 0,6 \mathrm{~Hz} \quad$ x $3,4 \pm 0,4 \mathrm{~Hz} ; \mathrm{p}<0,05)$ enquanto que os demais apresentaram uma resposta oposta $(4,5 \pm 0,9 \mathrm{~Hz}$ x 6,4 $\pm 1,4 \mathrm{~Hz} ; \mathrm{n}=4, \mathrm{p}<0,05)$. 
A

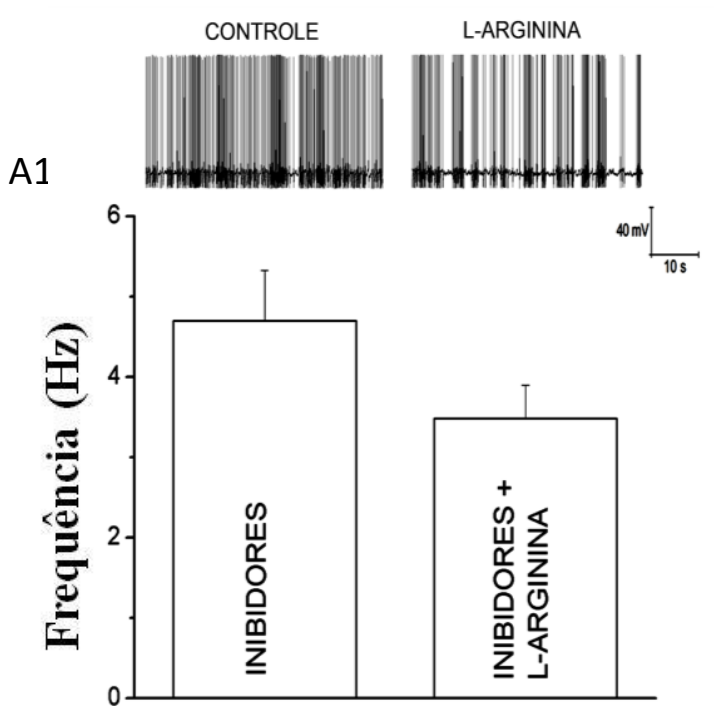

B

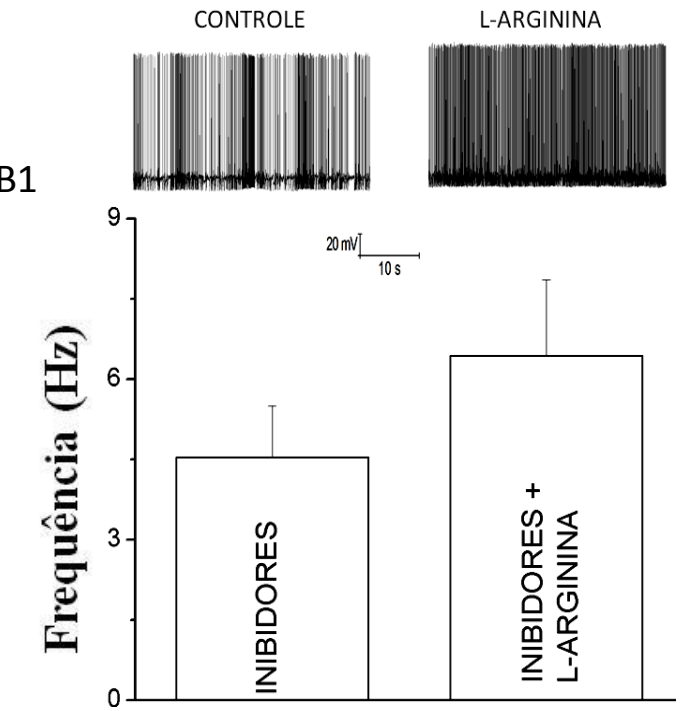

Figura 6. Modulação nitrérgica durante a retração glial por desidratação crônica. A e B são traçados típicos de voltagem obtidos de um dos neurônios de cada grupo analisados na situação controle (na presença de inibidores sinápticos - picrotoxina, CNQX e DL-AP5), e na presença dos inibidores mais $500 \mu \mathrm{M}$ de L- Arginina. Os registros mostram a atividade espontânea do neurônio durante 1 min de registro. Em A1 e B1 os gráficos de barras resumem os efeitos obtidos em 11 neurônios com 7 deles apresentando uma redução $(4,6 \pm 0,6 \mathrm{~Hz}$ x 3,4 $\pm 0,4 \mathrm{~Hz}$, Inibidores e Inibidores + L-arginina respectivamente; $\mathrm{p}<0,05)$ e os outros 4 , um aumento da frequência de potenciais de ação $(4,5 \pm 0,9 \mathrm{~Hz}$ x $6,4 \pm 1,4 \mathrm{~Hz} ; \mathrm{p}<0,05)$. Teste t paramétrico para ambos os grupos.

Por outro lado, quando os neurônios dos animais desidratados foram expostos a um inibidor da sintase do óxido nítrico, L-NAME $(100 \mu \mathrm{M})$, nós observamos que todos os neurônios registrados apresentaram um aumento na frequência de disparo (Figura 7) assim como observado na ausência do fluorocitrato (147). 
A

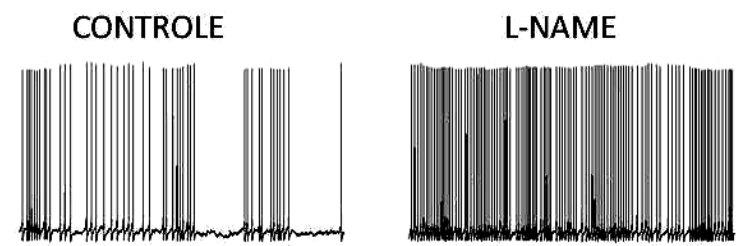

A1

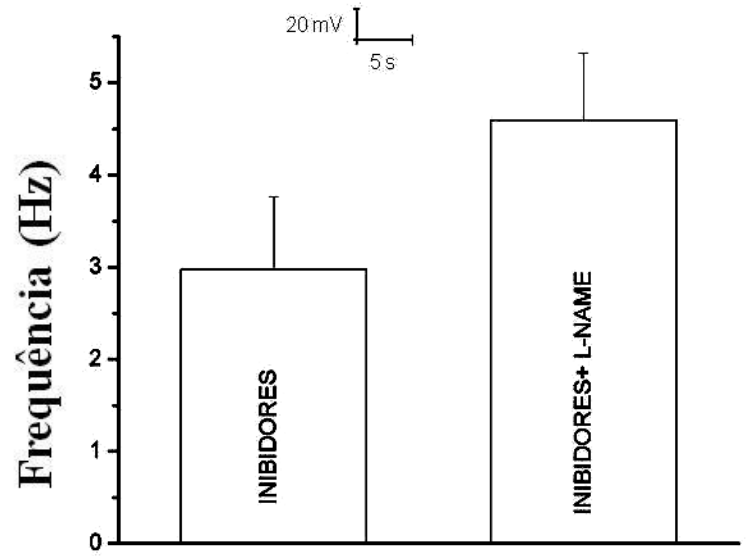

Figura 7. Inibição da enzima NOS aumenta a frequência de disparos dos neurônios MNCs após a retração glial. A, Traçados representativos da atividade intrínseca de um neurônio do grupo durante o controle, somente na presença de inibidores sinápticos, e após a superfusão com os inibidores mais o inibidor da NOS, L-NAME (100 $\mu \mathrm{M})$. A1, o gráfico de barras representa as médias ( \pm epm) obtidas de 8 neurônios registrados. Na presença do L-NAME houve um aumento na frequência de disparo quando comparado com os inibidores $(4,5 \pm 0,7 \mathrm{~Hz} \times 2,9 \pm 0,7 \mathrm{~Hz}$, respectivamente $-\mathrm{n}=8 ; \mathrm{p}<0,05-$ teste t paramétrico).

Devido aos diferentes resultados obtidos com o substrato do NO em 4 neurônios, a determinação do fenótipo celular faz-se essencial para o entendimento da modulação nitrérgica na ausência da interação neurônio-glia. Por esta razão, após o registro eletrofisiológico, o citoplasma das células foi coletado para analise. Assim, procurou-se determinar o fenótipo do neurônio utilizando-se de dois métodos distintos: eletrofisiológico e molecular por meio da RT-qPCR de uma única célula.

Em relação à determinação eletrofisiológica, os neurônios registrados, foram diferenciados a partir da análise de linearidade, ou não, da relação Corrente x Voltagem $(I-V)$. A linearidade dos pontos é característica de neurônios vasopressinérgicos, enquanto que seu 
desvio caracteriza os neurônios ocitocinérgicos. A não linearidade se deve a presença de uma corrente retificadora para fora (SOR) observada em voltagens mais positivas que $-60 \mathrm{mV}$ e/ou em decorrência de uma corrente retificadora para dentro (IR), ativada em potenciais mais hiperpolarizados que $-80 \mathrm{mV}$. Em contrapartida a linearidade presente nos neurônios VP se deve a ausência de ambas as correntes.

Como demonstrado na figura 8, entre os neurônios submetidos ao tratamento com Larginina $55 \%$ apresentaram uma relação $I-V$ linear caracterizando esta população de neurônios como vasopressinérgicos (n=6, sendo 5 células com redução da frequência, e 1 uma com aumento), e $45 \%$ não linear identificando-os como ocitocinérgicos ( $\mathrm{n}=5$, sendo 2 células com redução da frequência e 3 com aumento). Por outro lado, os neurônios registrados na presença do L-NAME apresentaram 50\% de cada fenótipo. Tais resultados indicam que as respostas obtidas na presença da L-arginina não se devem a uma diferença fenotípica dos neurônios registrados. 

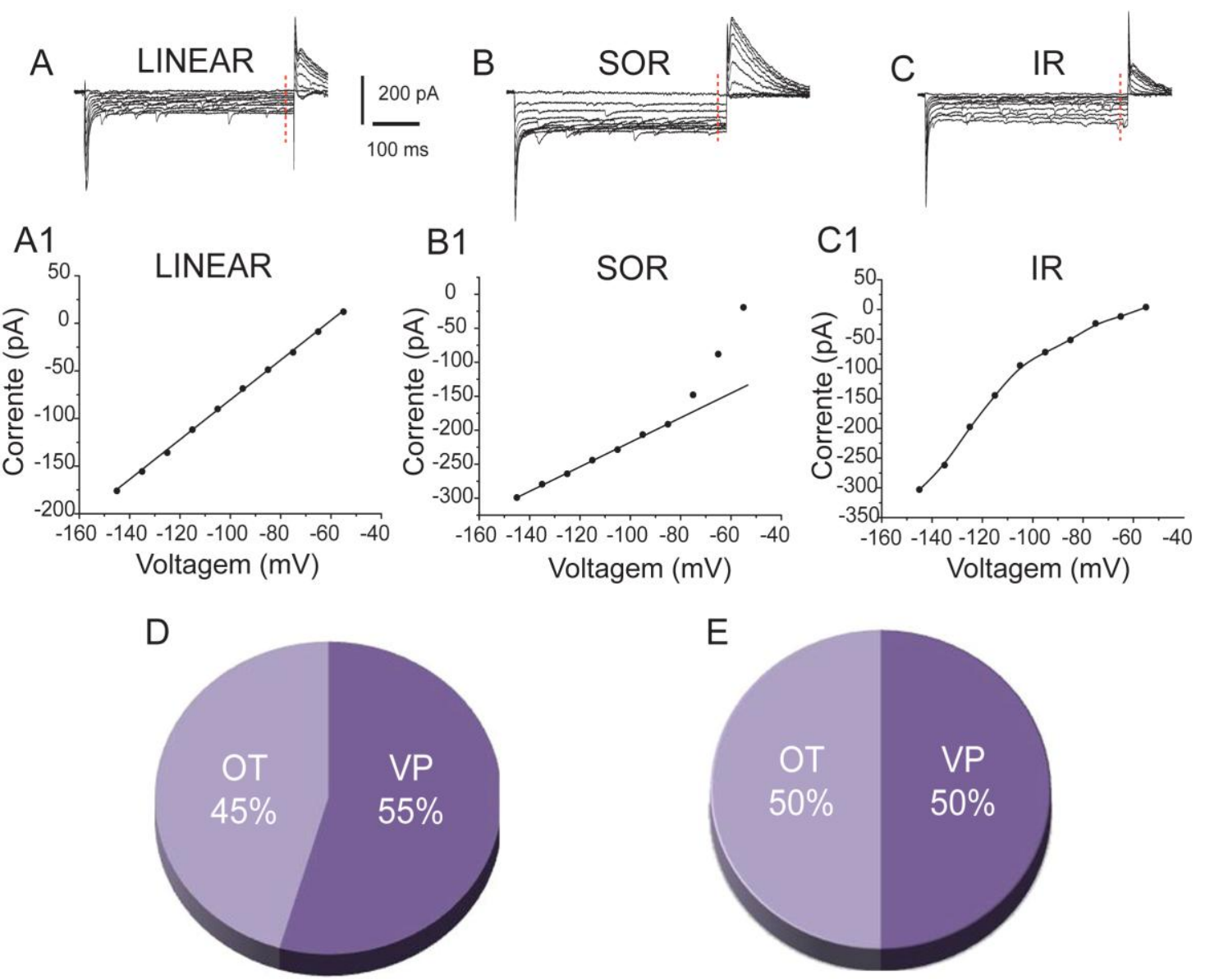

Figura 8. Caracterização fenotípica eletrofisiológica. Em A, registro de um neurônio vasopressinérgico obtido a partir de pulsos hiperpolarizantes de -40 a $-135 \mathrm{mV}$. A1, relação $I-V$ obtida a partir dos pontos delimitados pela linha vermelha tracejada. Note a linearidade da resposta. B e B1, registro de um neurônio ocitocinérgico e relação $I-V$ com retificação em voltagens mais despolarizadas que $-60 \mathrm{mV}$, indicando a presença da corrente retificadora de saída. $\mathbf{C}$ e $\mathbf{C 1}$ registro de um neurônio ocitocinérgico e relação $I-V$ com retificação de entrada observada em voltagem mais hiperpolarizadas que $-80 \mathrm{mV}$. D e E, distribuição percentual dos fenótipos eletrofisiológicos dos neurônios que foram superfundidos com o substrato do NO (L-arginina) e inibidor da NOS (L-NAME) respectivamente.

Por outro lado, com o PCR para célula única, os neurônios que apresentaram uma redução na frequência de potenciais de ação com a L-arginina $(n=7)$, foram identificados como vasopressinérgicos, e os neurônios que responderam com um aumento da frequência de potenciais de ação, foram identificados como ocitocinérgicos $(n=4)$. Como podemos observar o fenótipo eletrofisiológico não correspondeu ao molecular. 
4.2 Caracterização Eletrofisiológica do Fenótipo dos Neurônios Magnocelulares

Devido às discrepâncias fenotípicas encontradas com o protocolo eletrofisiológico quando o comparamos com o RT-qPCR nos animais desidratados, nós decidimos testar a confiabilidade do protocolo eletrofisiológico antes de dar continuidade aos experimentos e assim decidirmos qual método utilizar para caracterização fenotípica dos neurônios. Para isso, registramos 74 neurônios utilizando o protocolo eletrofisiológico descrito na literatura (61, 165) e a presença de relação $I-V$ não linear (correntes retificadores SOR e/ou IR), foi considerada como critério para identificação de neurônios ocitocinérgicos, enquanto que a ausência de retificação serviu à identificação de neurônios vasopressinérgicos. Em sequência, o citoplasma de cada célula registrada foi coletado para posterior determinação molecular do fenótipo neuronal utilizando o RT-qPCR para célula única.

Como pode ser observado na figura 9, de acordo com os critérios de distinção fenotípica eletrofisiológica, de um total de 74 neurônios registrados, 11 apresentaram relação $I-V$ linear caracterizando-os como vasopressinérgicos, enquanto que 39 apresentaram retificação de entrada (IR), 9 de saída (SOR) e 15 apresentaram ambas (SOR/IR) e foram caracterizados como ocitocinérgicos. 
A
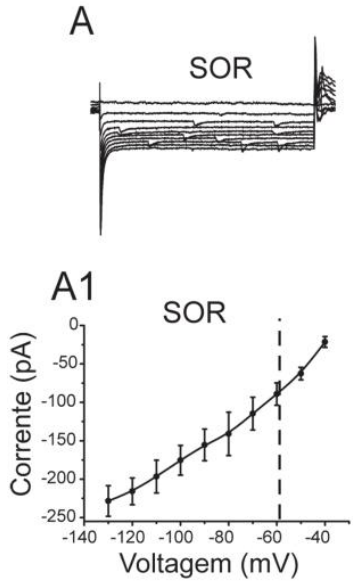

$\mathrm{E}$
B

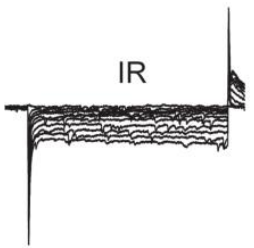

B1

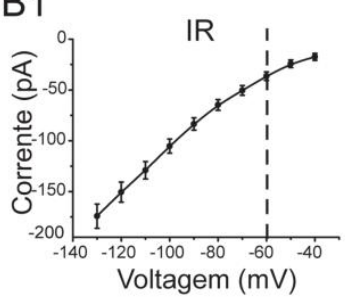

15

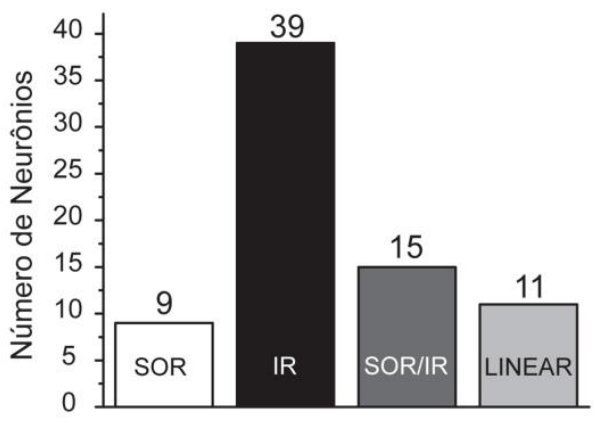

C

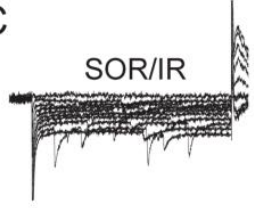

C1

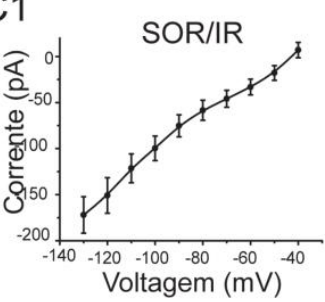

F

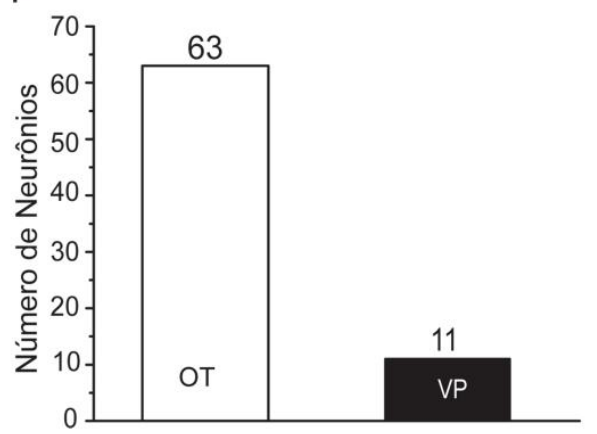

D

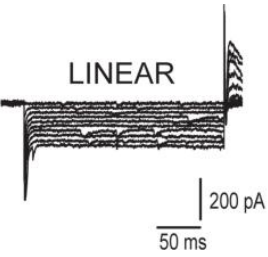

D1

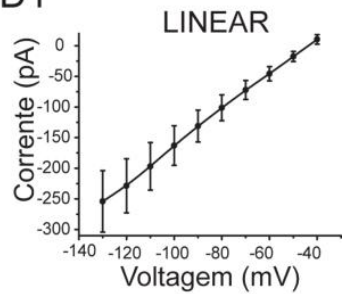

Figura 9. Distinção fenotípica utilizando protocolo eletrofisiológico: $\mathbf{A}$, B e $\mathbf{C}$ traçados representativos de neurônios ocitocinérgicos distinguidos pela presença de correntes retificadores de saída (SOR), entrada (IR) ou ambas (SOR/IR) obtidos em resposta a pulsos de voltagem hiperpolarizantes de $-40 \mathrm{mV}$ à $-135 \mathrm{mV}$ em passos de $-10 \mathrm{mV}$. D - traçado representativo de um neurônio vasopressinérgico. Os gráficos de barras resumem os diferentes tipos de correntes encontradas $(\mathbf{E})$ e a separação fenotípica de acordo com o protocolo eletrofisiológico $(\mathbf{F})$.

\subsection{Correlações do Fenótipo Eletrofisiológico com Molecular}

Após cada registro eletrofisiológico, o citoplasma da célula diluído, na solução de pipeta, foi imediatamente coletado para transcrição reversa. Todavia, como a quantidade RNAm coletado de uma única célula é relativamente pequena, procedemos a pré-amplificação do material. Assim sendo, inicialmente nos preocupamos em avaliar se este processo poderia alterar o fenótipo celular durante as análises. Para tanto registramos um novo grupo de 10 células, coletamos o citoplasma e uma primeira pré-amplificação foi feita. Em sequência 
realizamos a quantificação pelo PCR e o fenótipo foi determinado pela razão dos cDNAs (métodos, seção 3.5.3). Utilizando as mesmas amostras, uma segunda pré-amplificação foi feita e novamente elas foram quantificadas e o fenótipo determinado. Como podemos observar na tabela 1 a etapa de pré-amplificação das amostras não alterou o fenótipo celular.

\begin{tabular}{|c|c|c|}
\hline Amostra & Fenótipo: $1^{\circ}$ Pré-Amp & Fenótipo: $2^{\circ}$ Pré-Amp \\
\hline 1 & Intermediário & Intermediário \\
\hline 2 & VP & VP \\
\hline 3 & VP & OT \\
\hline 4 & OT & VP \\
\hline 5 & VP & VP \\
\hline 6 & VP & VP \\
\hline 7 & VP & VP \\
\hline 8 & VP & OT \\
\hline 9 & OT & Intermediário \\
\hline 10 & Intermediário & \\
\hline
\end{tabular}

Tabela 1. Controle positivo da pré-amplificação: Neurônios magnocelulares do SON foram préamplificados 2 vezes. Como mostrado, o fenótipo foi mantido, demonstrando que este procedimento não altera a proporção de RNAm dos neurônios.

Com a confiabilidade do método de pré-amplificação estabelecida, demos sequência a distinção fenotípica dos neurônios registrados previamente e observamos que dos 74 neurônios eletrofisiologicamente caracterizados, 13 tiveram $\frac{X_{V P, O}}{X_{O T, O}}<1$ indicando uma maior expressão de RNAm para ocitocina. A média \pm epm para estas células foram de $0,07 \pm 0,02$ variando de 0,002 a 0,3 . Quarenta e três neurônios apresentaram $\frac{X_{V P, O}}{X_{O T, O}}>1$ e foram identificados como vasopressinérgicos (razões variaram de 80,7 a 3097, com média de 554,3 \pm 205 ). Além disso, oito neurônios apresentaram $\frac{X_{V P, O}}{X_{O T, O}} \sim 1$ (média $=1,2 \pm 0,1$ variando de 0,7 a 1,7) e foram identificados como neurônios intermediários (Figura 10). 


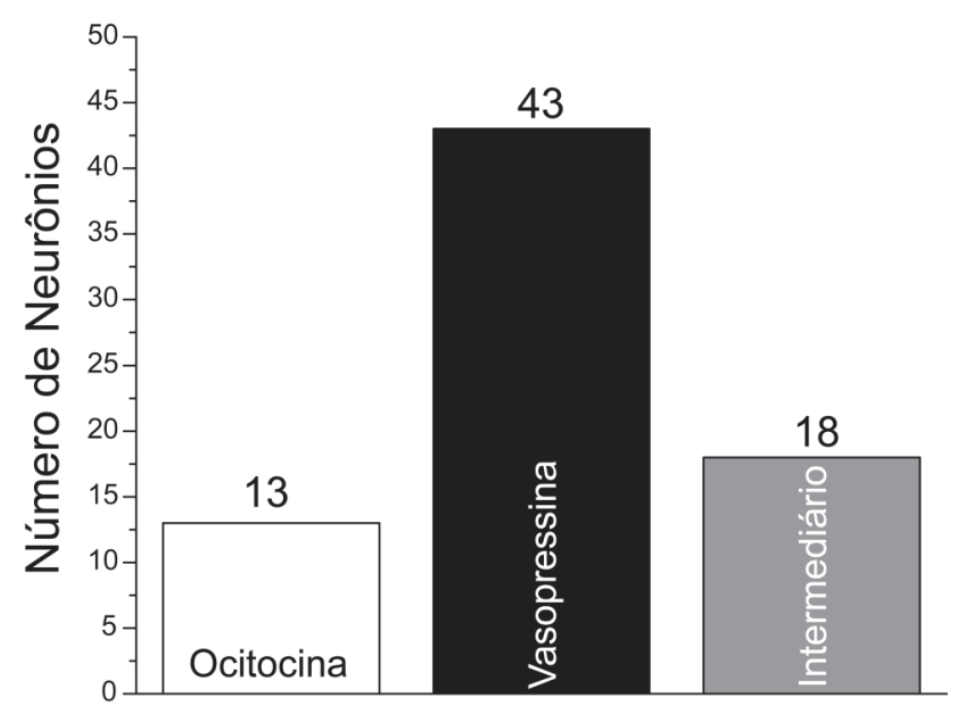

Figura 10. Identificação de neurônios magnocelulares pelo fenótipo molecular: Em um total de 74 neurônios registrados utilizando o protocolo eletrofisiológico, 43 foram caracterizados molecularmente como vasopressinérgicos, 13 como ocitocinérgicos e 18 como intermediários, expressando ambos os RNAm. Para maiores detalhes da análise e caracterização dos fenótipos utilizando PCR em tempo real, ver metodotos 3.5.

Correlacionando os dois métodos utilizados, podemos observar que dos 11 neurônios identificados como vasopressinérgicos pela eletrofisiologia, sete também foram caracterizados com o mesmo fenótipo pelo RT-qPCR; 1 foi identificado com ocitocinérgico, e 3 como intermediários. A nossa surpresa ficou por conta dos 63 neurônios identificados como ocitocinérgicos pela eletrofisiologia, uma vez que, daqueles, 36 neurônios foram molecularmente identificados como vasopressinérgicos, 15 intermediários e somente 12 foram identificados como sendo neurônios OT. Como podemos observar a análise molecular não corroborou os resultados eletrofisiológicos. Assim, não foi possível estabelecer qualquer relação segura entre a resposta elétrica e a característica molecular. A figura 11 mostra, graficamente, a correlação entre os dois métodos. 


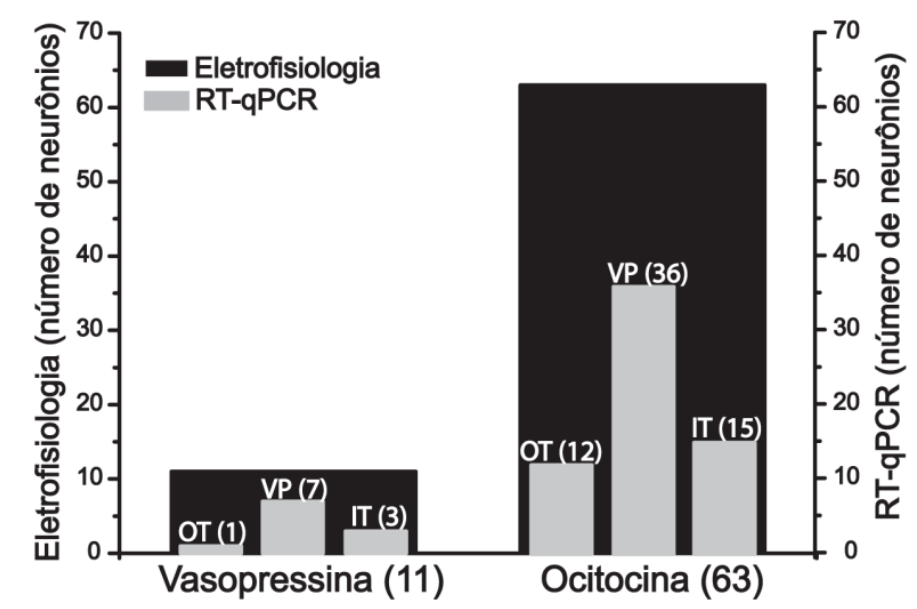

Figura 11. Correlação eletrofisiológica molecular. O gráfico de barras compara o fenótipo de 74 neurônios identificados tanto pela eletrofisiologia (barras pretas) quanto pelo RT-qPCR (barras cinza). De 11 neurônios identificados como vasopressinérgico pela eletrofisiologia, $9 \%(\mathrm{n}=1)$ foi identificado como ocitocinérgicos, $64 \%(n=7)$ foram vasopressinérgicos e $27 \%(n=3)$ como intermediários pelo RT-qPCR. Por outro lado, de 63 neurônios eletrofisiologicamente identificados como neurônios ocitocinérgicos, $57 \%(\mathrm{n}=36)$ foram identificados como vasopressinérgicos, 24\% ( $\mathrm{n}=15)$ como intermediários e somente $19 \%$ (n=12) como ocitocinérgicos.

Tais resultados colocam em dúvida a confiabilidade do método eletrofisiológico. Todavia, é importante salientar que como a expressão de RNAm não é equivalente à quantidade de neuropeptídeos sintetizados, experimentos capazes de avaliar o fenótipo pela expressão de RNAm e ao mesmo tempo pelo neuropeptídeo sintetizado, são de suma importância para caracterizar o fenótipo dos neurônios com mais precisão. Assim, para resolvermos este problema, nós realizamos experimentos que englobaram: registros eletrofisiológicos, PCR em tempo real, e marcação do neurônio registrado com o traçador biocitina, para posterior analise por imunofluorescência, em um único neurônio. Estes experimentos são importantes para podermos correlacionar a expressão de RNAm com a síntese de peptídeo em cada fenótipo encontrado e compararmos, mais precisamente, com os resultados do protocolo eletrofisiológico. 


\subsection{Tripla Caracterização de um Único Neurônio}

Utilizando a tripla caracterização, 22 neurônios foram eletrofisiológicamente identificados, o citoplasma foi coletado para analise do fenótipo pelo RT-qPCR, e por fim, os neurônios previamente marcados com biocitina foram identificados utilizando a imunofluorescência. Encontramos 11 neurônios imunorreativos para vasopressina e 11 para ocitocina. Inicialmente, quando comparamos esses dados com a biologia molecular, observamos que das células identificadas pela imunofluorescência como vasopressinérgicas, 9 também o foram pelo RT-qPCR, e os dois restantes foram caracterizados como intermediários. Já em relação aos neurônios identificados como ocitocinérgicos pela imunofluorescência, o mesmo fenótipo foi encontrado com o RT-qPCR (Figura 12). 

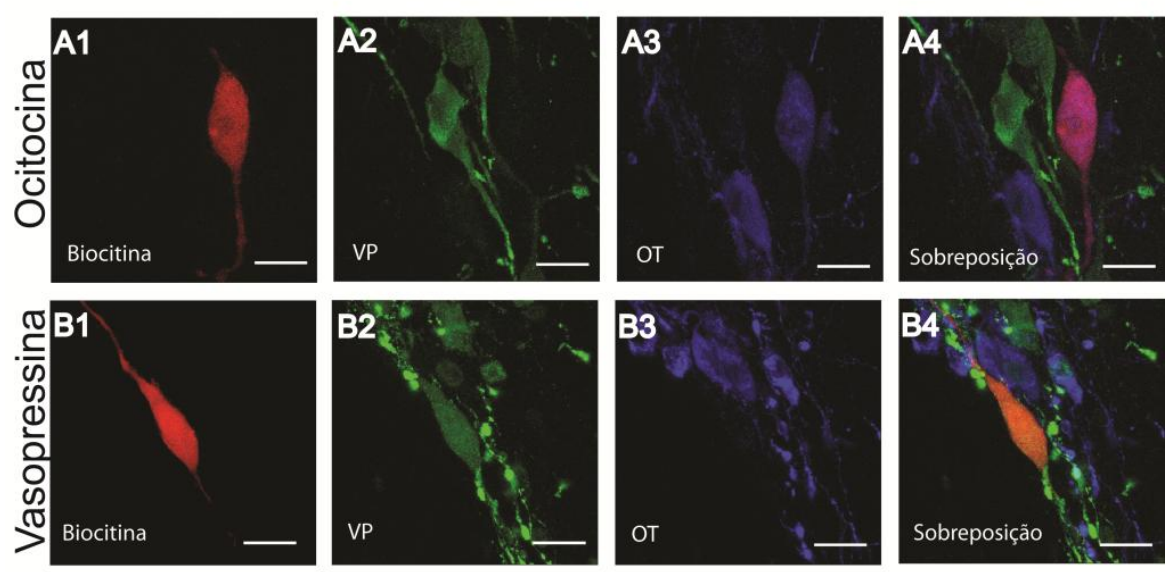

C

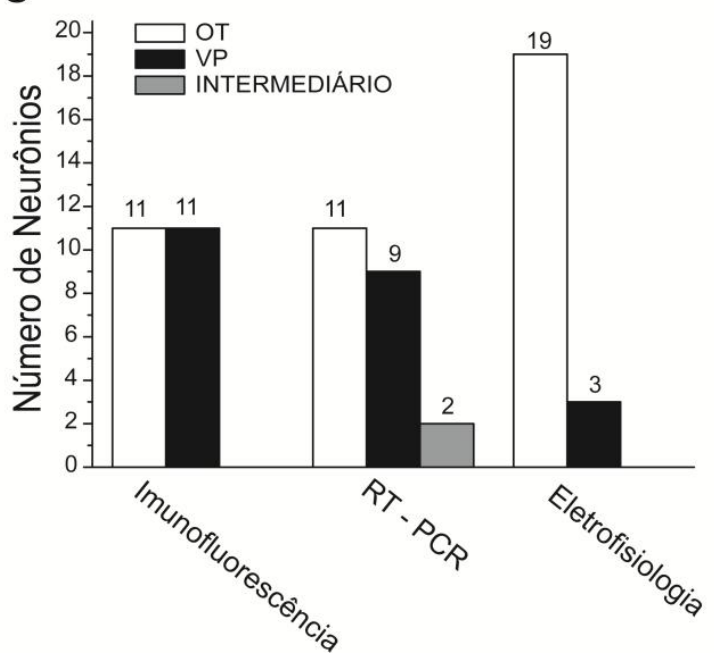

Figura 12. Caracterização fenotípica de neurônios magnocelulares: Fotomicrografias representativas obtidas de dois neurônios imunohistoquímicamente identificados. Os neurônios foram preenchidos com biocitina $(0,2 \%)$ durante o registro eletrofisiológico e revelados pela estreptavidina conjugada com Alexa fluor 350 (vermelho -A1 e B1). Em seguida, os neurônios foram marcados para vasopressina (A2 e B2) e ocitocina (A3 e B3) e a identificação do fenótipo foi feita pela colocalização (A4 e B4). Os painéis superiores mostram um neurônio registrado eletrofisiologicamente e imunohistoquímicamente positivo para ocitocina e os inferiores para vasopressina. A barra branca corresponde a $15 \mu \mathrm{m}$. O gráfico de barras representa a distribuição fenotípica dos neurônios de acordo com cada técnica: imunofluorescência, RT-qPCR e com o protocolo eletrofisiológico (C). Uma alta correlação entre a imunofluorescência e qPCR pode ser observada, no entanto o mesmo não é verdadeiro quando comparamos estas técnicas com a eletrofisiologia.

Todavia, com a eletrofisiologia, notamos que a maioria das células registradas apresentaram retificações de entrada, saída ou ambas $(n=19)$, e somente 3 não apresentaram 
retificações. Quando comparamos estes resultados com os dois métodos anteriores, nós observamos que somente 10 células (1 VP e 9 OT) tiveram correlação com imunofluorescência, e 8 com PCR e imunofluorescência, sendo os outros 2 neurônios caracterizados como intermediários pelo RT-qPCR (Tabela 2, figura 12C).

\begin{tabular}{|c|c|c|c|}
\hline \# Cel & Eletrofisiologia & RT-qPCR Razão/Fenótipo & Imunofluorescência \\
\hline $\mathbf{1}$ & IR (OT) & $3,10(\mathrm{VP})$ & VP \\
\hline $\mathbf{2}$ & IR (OT) & $*(\mathrm{OT})$ & OT \\
\hline $\mathbf{3}$ & IR (OT) & $143,6(\mathrm{VP})$ & VP \\
\hline $\mathbf{4}$ & SOR (OT) & $*(\mathrm{VP})$ & VP \\
\hline $\mathbf{5}$ & IR (OT) & $0,02(\mathrm{OT})$ & OT \\
\hline $\mathbf{6}$ & SOR/IR (OT) & $0,01(\mathrm{OT})$ & OT \\
\hline $\mathbf{7}$ & LINEAR (VP) & $0,01(\mathrm{OT})$ & OT \\
\hline $\mathbf{8}$ & IR (OT) & $0,01(\mathrm{OT})$ & OT \\
\hline $\mathbf{9}$ & SOR (OT) & $25,61(\mathrm{VP})$ & VP \\
\hline $\mathbf{1 0}$ & LINEAR (VP) & $4,91(\mathrm{VP})$ & VP \\
\hline $\mathbf{1 1}$ & IR (OT) & $1,2($ Intermediário) & OT \\
\hline $\mathbf{1 2}$ & IR (OT) & $*(\mathrm{VP})$ & VP \\
\hline $\mathbf{1 3}$ & LINEAR (VP) & $0,01(\mathrm{OT})$ & OT \\
\hline $\mathbf{1 4}$ & SOR (OT) & $*(\mathrm{VP})$ & VP \\
\hline $\mathbf{1 5}$ & SOR (OT) & $0,03(\mathrm{OT})$ & OT \\
\hline $\mathbf{1 6}$ & IR (OT) & $0,01(\mathrm{OT})$ & OT \\
\hline $\mathbf{1 7}$ & IR (OT) & $1,4($ Intermediário $)$ & OT \\
\hline $\mathbf{1 8}$ & IR (OT) & $*(\mathrm{VP})$ & VP \\
\hline $\mathbf{1 9}$ & IR (OT) & $*(\mathrm{VP})$ & VP \\
\hline $\mathbf{2 0}$ & IR (OT) & $0,05(\mathrm{OT})$ & OT \\
\hline $\mathbf{2 1}$ & IR (OT) & $75,69(\mathrm{VP})$ & VP \\
\hline $\mathbf{2 2}$ & IR (OT) & $25,31(\mathrm{VP})$ & VP \\
\hline
\end{tabular}

Tabela 2. Tripla caracterização de um único neurônio. A tabela mostra o fenótipo identificado por três métodos distintos: Eletrofisiologia, RT-qPCR e imunofluorescência em um único neurônio. Note a alta correlação entre o RT-qPCR e Imunofluorescência e a baixa correlação de ambos com a eletrofisiologia. * neurônios que expressaram somente um tipo de RNAm. 
4.5 Caracterização Fenotípica de Neurônios Magnocelulares do Núcleo Paraventricular

\subsubsection{Caracterização Eletrofisiológica}

Uma vez que o núcleo paraventricular também é composto por neurônios magnocelulares, nos preocupamos em avaliar a confiabilidade do protocolo eletrofisiológico também para este grupo de neurônios. Os mesmos procedimentos eletrofisiológicos e de RTqPCR descritos para o SON foram seguidos nesta etapa de experimentos. Levando em consideração que neurônios magnocelulares da porção lateral do PVN são na sua maioria vasopressinérgicos $(76,86,122)$, optamos por caracteriza-los e de acordo com o protocolo eletrofisiológico, esperaríamos encontrar um grande numero de neurônios com relações I-V lineares, entretanto, dos 22 neurônios registrados 19 deles apresentaram correntes retificadoras. Assim, como pode ser observado na figura 13 para neurônios magnocelulares da porção lateral do PVN também obtivemos os 4 tipos de respostas, ou seja, das 22 células analisadas, 5 delas apresentaram SOR, 11 IR, 3 ambas as retificações (SOR/IR) e somente 3 apresentaram relações I-V lineares. Portanto, classificando os neurônios de acordo com este protocolo, 19 foram caracterizados como ocitocinérgicos e 3 como vasopressinérgicos (Figura 13). 


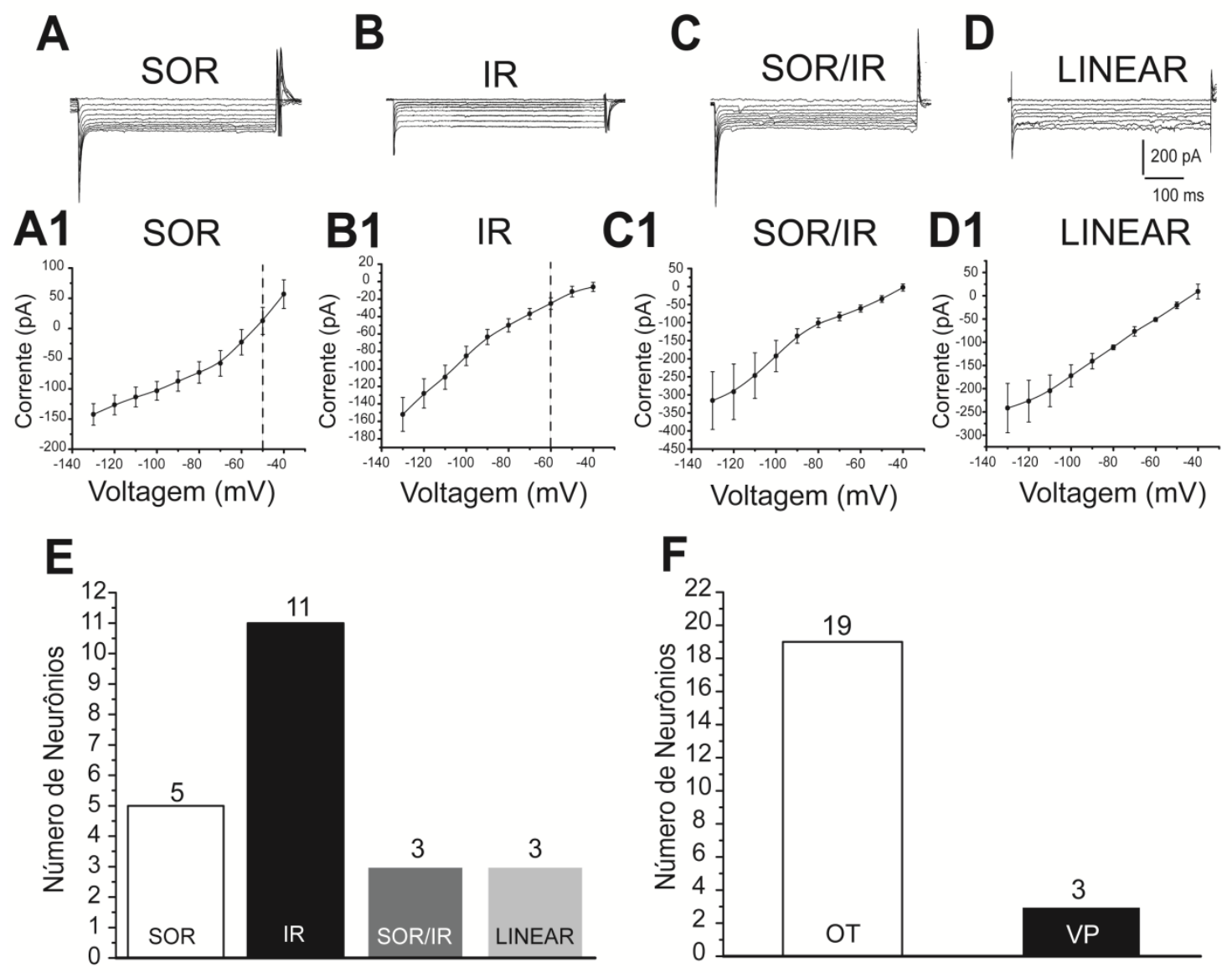

Figura 13. Identificação fenotípica de neurônios magnocelulares do PVN lateral pela eletrofisiologia. Neurônios magnocelulares do PVN lateral $(n=22)$ foram identificados pelo protocolo electrofisiológico, seguindo os mesmos critérios descritos na seção 3.3 para neurônios do SON. Quatro relações $I-V$ foram encontradas no PVN lateral, sendo três delas correntes retificadoras, e uma linear (A, B, C e D respectivamente). A1, B1, C1 e D1 mostram as médias das relações $I-V$ para cada caso encontrado. Dos 22 neurônios registrados, 19 apresentaram correntes retificadoras (5 SOR; 11 IR e 3 SOR/IR) que caracterizaram essas células como ocitocinérgicas, e 3 tiveram uma relação $I$ - $V$ linear e foram identificados como vasopressinérgicas. O gráfico de barras resume os dados encontrados em relação às retificações $(\mathbf{E})$ e a classificação fenotípica, de acordo com o protocolo utilizado $(\mathbf{F})$.

\subsubsection{Caracterização Fenotípica do PVNmL pelo RT-qPCR}

Em relação à caracterização molecular dos 22 neurônios previamente analisados pela eletrofisiologia, 16 deles foram identificados como vasopressinérgicos $\operatorname{com} \frac{X_{V P, O}}{X_{O T, O}}>1$ (variando entre 109,7 a 2296,3, com média $=4433,4 \pm 2849,8)$ sendo que 6 dos 16 
expressaram somente RNAm para vasopressina. Quatro neurônios tiveram $\frac{X_{V P, O}}{X_{O T, O}}<1(0,0007$ a 0,04 , com media $=0,012 \pm 0,009)$ e foram identificados como neurônios ocitocinérgicos. Os dois neurônios restantes foram identificados como intermediários, $\frac{X_{V P, O}}{X_{O T, O}} \sim 1$ (média $=0,8 \pm$ 0,6; de 0,15 a 1,5). A comparação dos fenótipos descrita pelo protocolo eletrofisiológico e RT-qPCR para célula única, novamente, demonstrou baixa correlação, com somente quatro neurônios descritos com o mesmo fenótipo em ambos os métodos utilizados (Figura 14).

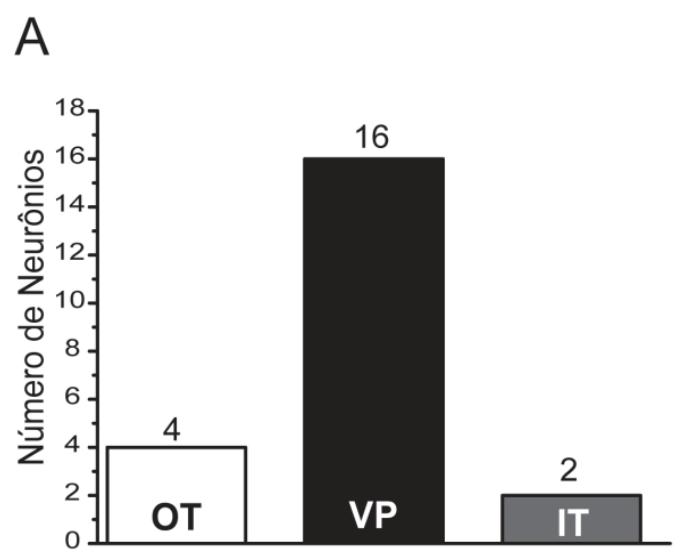

B

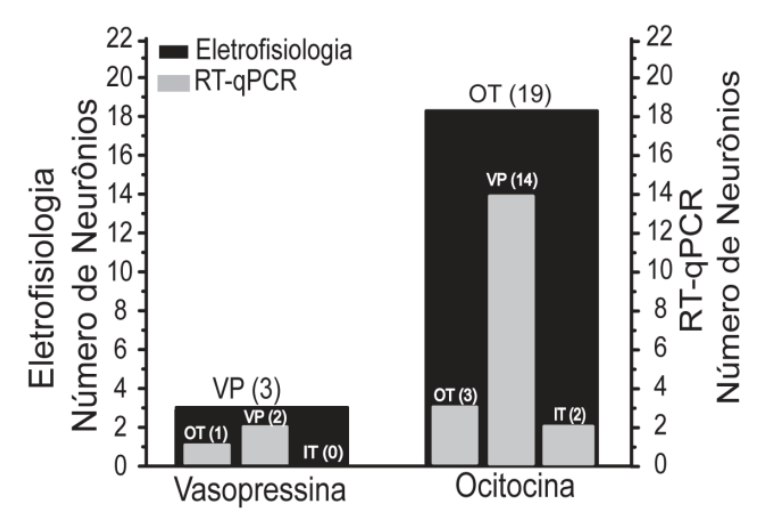

Figura 14. Caracterização molecular do fenótipo dos neurônios magnocelulares do PVN lateral.

A mostra a distribuição do fenótipo molecular dos neurônios previamente distinguidos pelo protocolo eletrofisiológico. Das três células identificadas como vasopressinérgica pela eletrofisiologia, 2 também foram caracterizadas como vasopressinérgica pelo RT-qPCR e uma como ocitocinérgica (B). Entretanto das 19 células ocitocinérgicas (presença das correntes retificadoras), somente 3 foram identificadas como ocitocinérgica pelo RT-qPCR. Seis cédulas expressaram somente RNAm para vasopressina.

Isso significa que do total de neurônios identificados com o protocolo eletrofisiológico, 75\% dos neurônios do SON e 77\% dos neurônios do PVN lateral não corresponderam ao fenótipo molecular obtido pelo RT-qPCR. 


\subsection{Implicações Fisiológicas}

A importância de caracterizar adequadamente o fenótipo dos neurônios magnocelulares pode ser facilmente apreciada em condições onde o equilíbrio hidroeletrolítico é desafiado. Sob estas condições, é razoável supor que os neurônios magnocelulares, expressando RNAm tanto para OT quanto para VP, priorizem a síntese e a liberação do peptídeo necessário para o reestabelecimento de equilíbrio hidroeletrolítico. Ou seja, a proporção dos fenótipos do SON poderia ser alterada. Portanto, para testar essa hipótese ratos foram submetidos à restrição hídrica ou à sobrecarga salina durante 7 dias (ver métodos 3.5.6). Em sequência, a proporção fenotípica em cada condição experimental foi avaliada e comparada com o grupo de animais controle. Como podemos observar na figura 15, nos animais submetidos a 7 dias de restrição hídrica houve um aumento de neurônios imunorreativos para vasopressina e uma redução no número de neurônios imunorreativos para ocitocina quando os comparamos com animais controle $(\mathrm{VP}=60,4 \pm 3$ vs $84,1 \pm 5.3$ e OT $=61,7 \pm 3$ vs $48,5 \pm 1,6 ; p<0,005$ e $p<0,05$ Controle vs restrição hídrica, respectivamente). Entretanto, em relação ao grupo de animais submetidos a sobrecarga salina, nós não observamos diferenças significativas na proporção de neurônios VP $(60,4 \pm 3$ vs $64,5 \pm 4 ; p>0,05)$ e OT $(61,7 \pm 3$ vs $54 \pm 3,7 ; p>0,05)$ quando os comparamos com o grupo controle. 

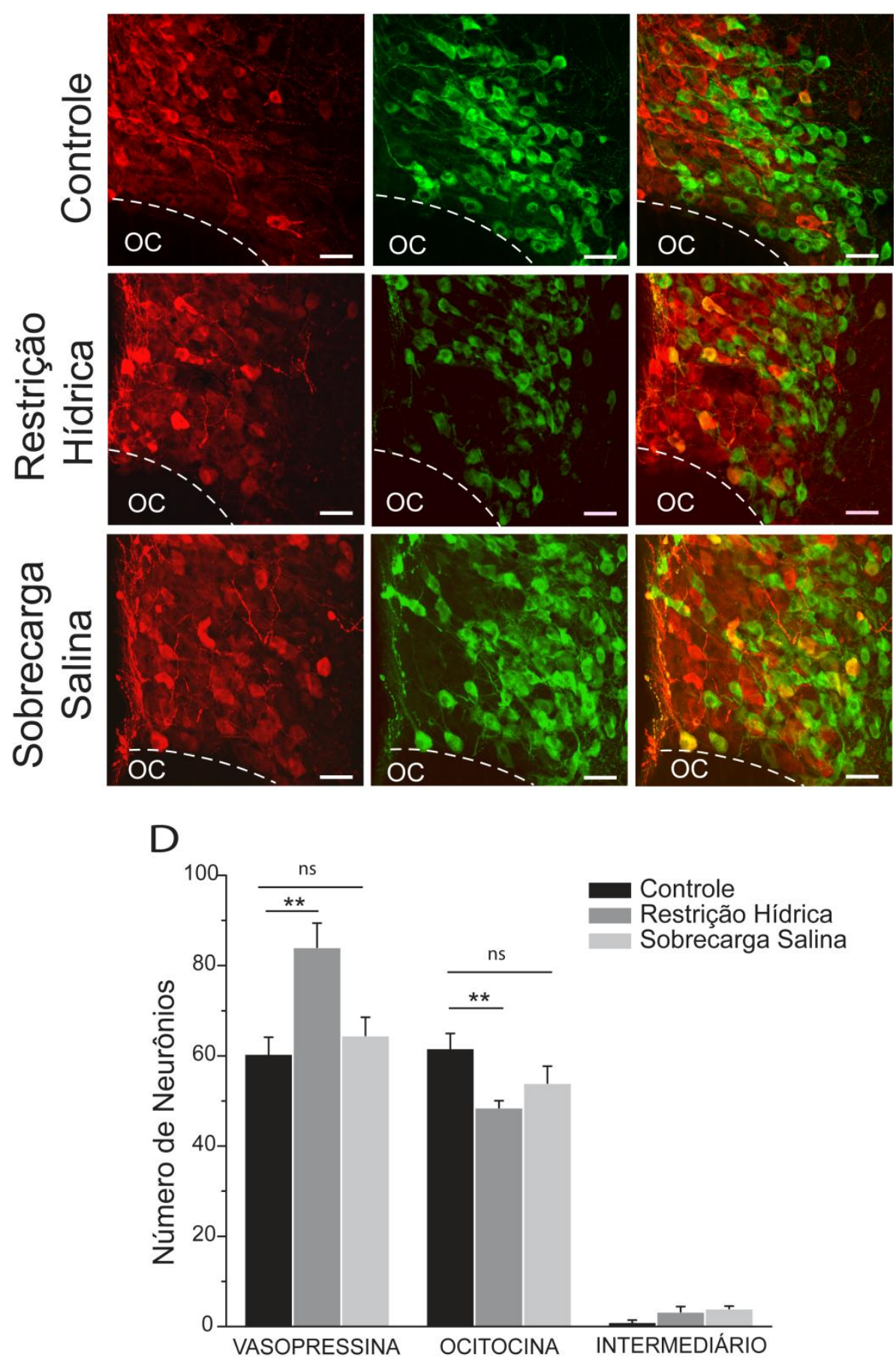

Figura 15. Desequilíbrio hidroeletrolítico altera a proporção de fenótipos dos MNCs. Fotomicrografias mostrando neurônios imunorreativos para VP (vermelho) e OT (verde) em situação controle (A), após restrição hídrica $(\mathbf{B})$, e sobrecarga salina $(\mathbf{C})$. A3- C3 representa a sobreposição das imagens. O Gráfico de barras em $\mathbf{D}$ resume o número de neurônios imunorreativos encontrados para cada condição experimental. A estatística foi realizada utilizando ANOVA One Way não paramétrica com pós-teste de Bonferroni $* * \mathrm{p}<0,005$. Barras horizontais $=15 \mu \mathrm{m} . \mathrm{OC}=$ quiasma óptico. 
Dos resultados até aqui apresentados, podemos concluir que o protocolo eletrofisiológico não é eficaz na discriminação dos fenótipos dos neurônios magnocelulares, quando se utiliza a configuração whole cell. Além disso, a caracterização do fenótipo neuronal utilizando o protocolo eletrofisiológico se torna crítico em situações onde a proporção fenotípica esta alterada. Já com relação aos resultados obtidos com as células gliais, o envolvimento destas na modulação nitrérgica dos MNCs parece interferir somente em neurônios ocitocinérgicos uma vez que nos vasopressinérgicos a L-arginina produziu o mesmo efeito observado previamente por nós $(34,147)$.

Como o RT-qPCR para célula única demonstrou $83 \%$ de coerência entre a expressão de RNAm e a síntese de peptídeos para os neurônios do SON, este foi adotado por nós para caracterizar o fenótipo celular nos próximos experimentos.

\subsection{Canais HCN e Modulação Nitrérgica}

Uma vez que alterações na atividade intrínseca dos neurônios magnocelulares durante a modulação nitrérgica ocorrem por meio dos canais de cátions ativados por hiperpolarização e nucleotídeos cíclicos (HCN) (130), avaliamos ainda se esta modulação persiste quando a interação neurônio-glia está ausente. Para tal, utilizamos neurônios magnocelulares isolados e avaliamos o efeito do óxido nítrico sobre os canais $\mathrm{HCN}$. A figura 16 apresenta os resultados obtidos. Aplicação de $500 \mu \mathrm{M}$ de L-arginina produziu uma redução significativa na corrente estacionária $(-19 \pm 5 \mathrm{pA} v s-6,8 \pm 1,8 \mathrm{pA}$, em $-135 \mathrm{mV})$. Adicionalmente, ajustando uma exponencial simples para calcular a constante de tempo do componente do processo de ativação da corrente $\mathrm{I}_{\mathrm{h}}$, nós observamos que na presença da L-arginina houve um aumento significativo quando comparado com o controle $(109,6 \pm 26 \mathrm{~ms}$ vs $167,7 \pm 32 \mathrm{~ms}$, em -135 $\left.\mathrm{mV} ; \mathrm{n}=6,{ }^{*} \mathrm{p}<0,05\right)$. Assim, esses dados demonstraram que a modulação nitrérgica nos canais HCN ocorre independentemente das células gliais. 
A

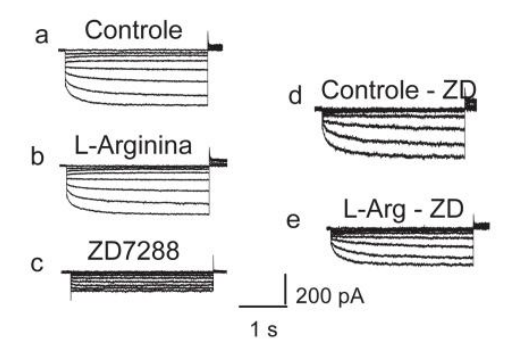

C

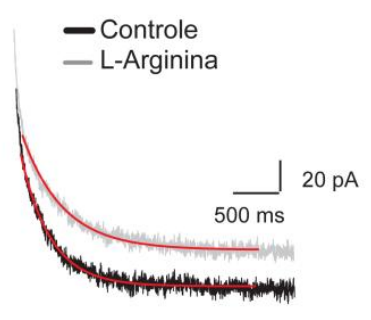

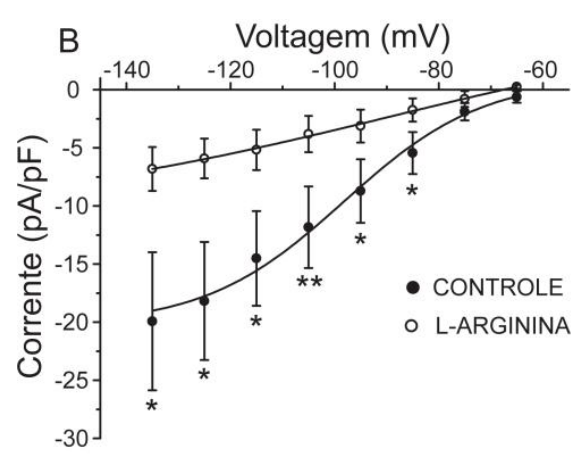

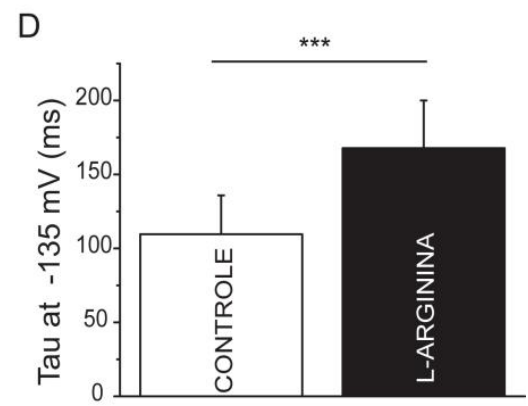

Figura 16. Efeito do óxido nítrico nos canais HCN em neurônios magnocelulares isolados. Em A, estão representados traçados típicos obtidos em um neurônio do grupo demonstrando o efeito da superfusão com L-arginina, seguida da aplicação do bloqueador específico ZD7288. Observa-se uma redução da corrente total sensível ao ZD7288. Em D,E a corrente subtraída (L-arginina - ZD7288) é evidenciada numa relação corrente voltagem e comparada com o grupo controle. Na relação $I-V$ em $\mathbf{B}$, nota-se que quando os neurônios são submetidos a L-arginina $(500 \mu \mathrm{M})$ há uma redução expressiva da amplitude da corrente total quando comparada com o controle $(-19 \pm 5 \mathrm{pA} \times-6,8 \pm 1,8 \mathrm{pA}$, em -135 $m V, n=9 p<0,05)$. Em $\mathbf{C}$, traçado representativo de um neurônio do grupo demonstrando a ativação da corrente, em $-135 \mathrm{mV}$, ajustada com uma exponencial simples (em vermelho) para calcular a constante de tempo do processo. O grupo controle está representado em preto e o grupo submetido a L-arginina está representado em cinza. O gráfico de barras, em D, resume a média do grupo no controle e após o tratamento com L-arginina. Note o aumento na constante de tempo na presença da Larginina. 


\subsection{Neurônios Magnocelulares do SON Produzem NO}

Como observamos nos experimentos anteriores, a modulação nitrérgica da corrente $\mathrm{I}_{\mathrm{h}}$ ocorre na ausência das células gliais. Entretanto, considerando que tais células são capazes de produzir NO (100), nossa próxima pergunta foi: Onde é produzido o NO?

Como a sintase do óxido nítrico foi encontrada nos neurônios magnocelulares e sua expressão no hipotálamo está correlacionada com aumentos da osmolalidade plasmática (21, 144) o próximo passo consistiu em avaliar se os neurônios do SON são capazes de produzir oxido nítrico e este por sua vez atuar autocrinamente ou paracrinamente. Inicialmente, foram feitos experimentos de fluorescência com neurônios isolados para verificar a produção de NO, em condições de aumento da osmolalidade, sem a interferência dos astrócitos. Para tanto, os neurônios foram dissociados e incubados com um marcador fluorescente da produção de NO (DAF-FM - $10 \mu \mathrm{M}$ ) e com auxilio da microscopia confocal nós observamos as alterações na produção do NO durante uma situação controle (solução de Hank - Ver metodologia) seguido de um estímulo hiperosmótico de 330 mosm/(kg. $\mathrm{H}_{2} \mathrm{O}$ ) (Solução de Hank ajustada com manitol) e como controle positivo nós utilizamos um doador de NO (SIN 1, $100 \mu \mathrm{M})$.

Como demonstrado na figura 17 , durante o estimulo hipertônico houve um aumento na fluorescência indicando aumento na produção de NO. Para demonstrar que o aumento na produção de NO foi devido ao estimulo hipertônico, nós utilizamos um doador de NO (SIN1 $100 \mu \mathrm{M})$ como controle positivo e observamos um aumento ainda maior. 


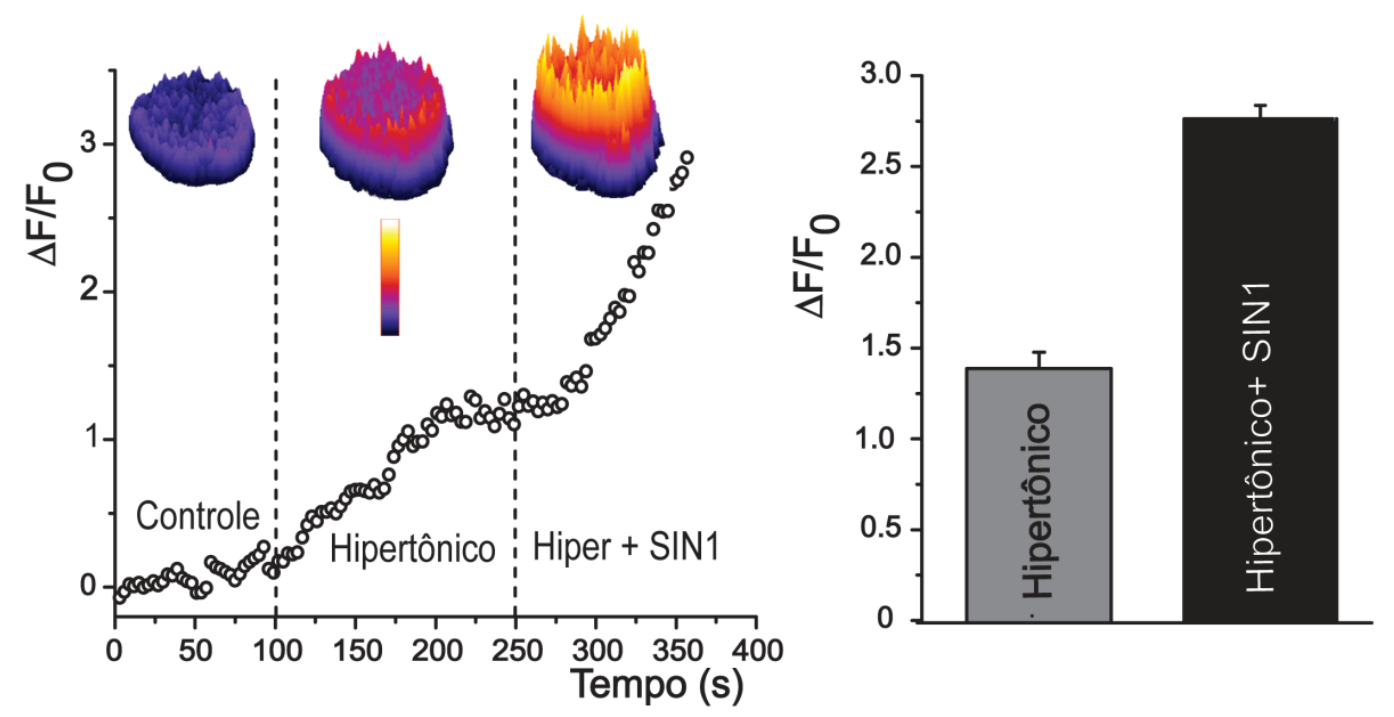

Figura 17. Hipertonicidade aumenta a produção de NO em neurônios do supraóptico. A -

Evolução temporal da produção de NO de um único neurônio isolado do grupo na condição controle, durante o estimulo hipertônico e após tratamento com doador de NO (SIN1 $100 \mu \mathrm{M})$. As figuras no topo do gráfico representam "surface plots" do mesmo neurônio em cada condição experimental e a barra colorida, de cores frias a cores mais quentes, indica o aumento na produção de NO. B média $\Delta \mathrm{F} / \mathrm{F}_{0}$ (media $\left.\pm \mathrm{epm}\right)$ obtida de 13 células em 3 experimentos independentes. $\Delta \mathrm{F}=\left(\mathrm{F}-\mathrm{F}_{0}\right)$ é a diferença entre a fluorescência obtida em um intervalo de tempo (F) e a fluorescência de fundo ("background") $\left(\mathrm{F}_{0}\right)$. A média dos valores foi calculada com os maiores valores de $\Delta \mathrm{F} / \mathrm{F}_{0}$ para cada situação.

A identificação dos neurônios isolados como sendo magnocelulares foi realizada através de experimentos de imunofluorescência. Como mostrado na figura 18, nós encontramos neurônios com morfologias distintas, os circulares e os neurônios com axônios e dendritos. Quanto à marcação dos neurônios para determinação do fenótipo celular, observamos que apesar da especificidade dos anticorpos, varias colocalizações foram observadas. 

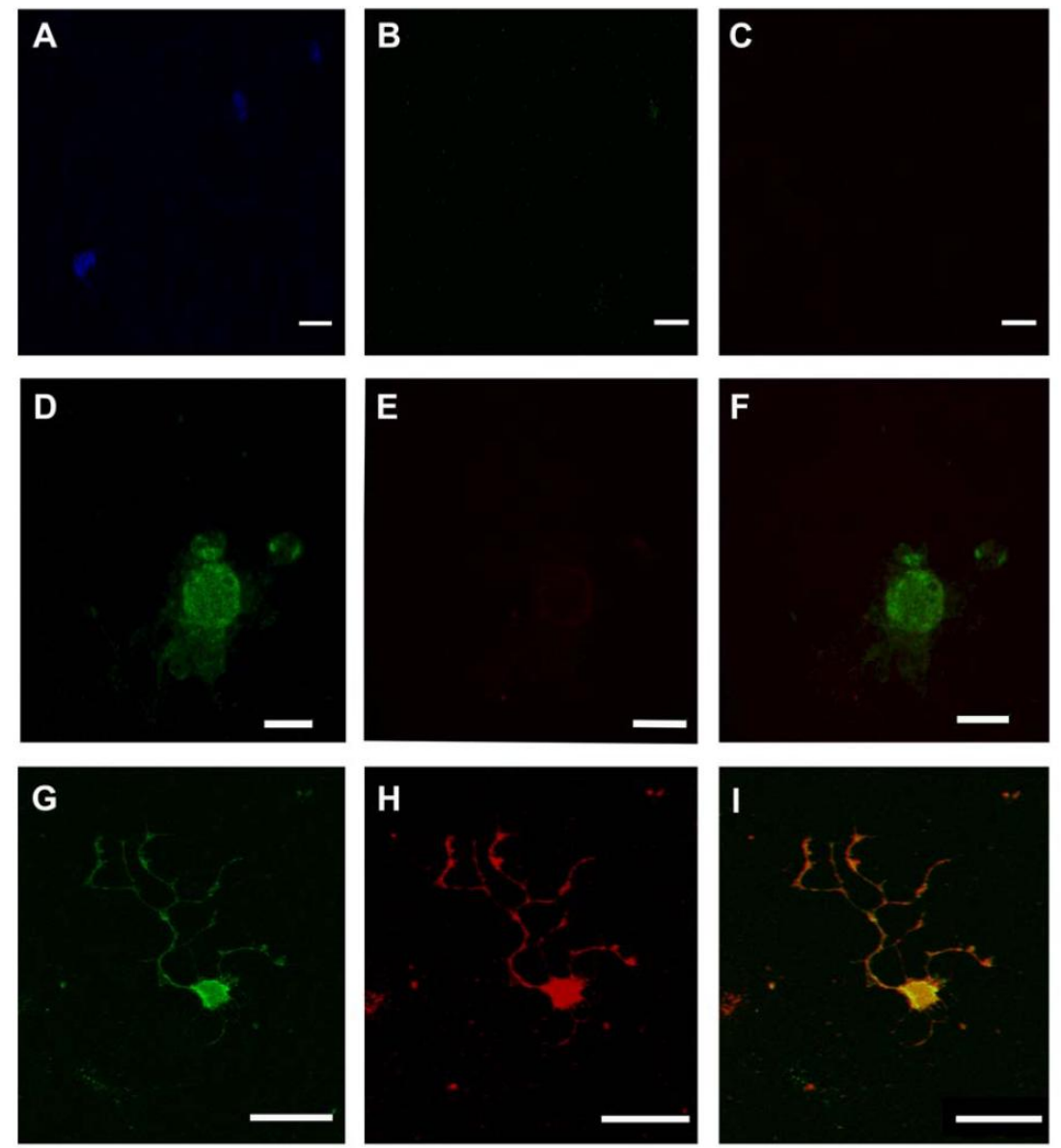

Figura 18. Imunofluorescência para neurônios vasopressinérgicos e ocitocinérgicos do SON isolados. Os neurônios isolados foram incubados com anticorpos específicos para identificação fenotípica (vasopressina em vermelho e ocitocina em verde). A colocalização é mostrada em amarelo em F e I. Dois tipos de morfologia neuronal foram identificados após 24 horas em cultura: Neurônios circulares (D) e com axônios e dendritos $(\mathbf{G})$. A, B e C são experimentos controles somente com anticorpo secundário e na presença de DAPI (marcador nuclear). Escala: 7,5 $\mu \mathrm{m}$ (A-F) e $25 \mu \mathrm{m}$ (G-I).

Frente ao alto número de neurônios colocalizados e sabendo que os neurônios magnocelulares do núcleo supraóptico possuem neurônios com fenótipos intermediários, isto é, produzem os dois peptídeos, seria razoável pensar em um neurônio isolado com fenótipo intermediário. Todavia, a porcentagem de colocalização, indicando duplo fenótipo em condições basais é baixa e neste experimento observamos que maior parte células tiveram colocalização $(\sim 70 \%)$. Assim, na tentativa de sanar este problema nós repetimos o mesmo tipo de experimento, utilizando fatias do SON e avaliamos as colocalizações com o intuído de 
investigar se o processo de dissociação dos neurônios estava alterando sua fisiologia. Como demonstrado na figura 19, utilizando os mesmos anticorpos, para imunofluorescência em fatias, nós não observamos a mesma intensidade de colocalizações.

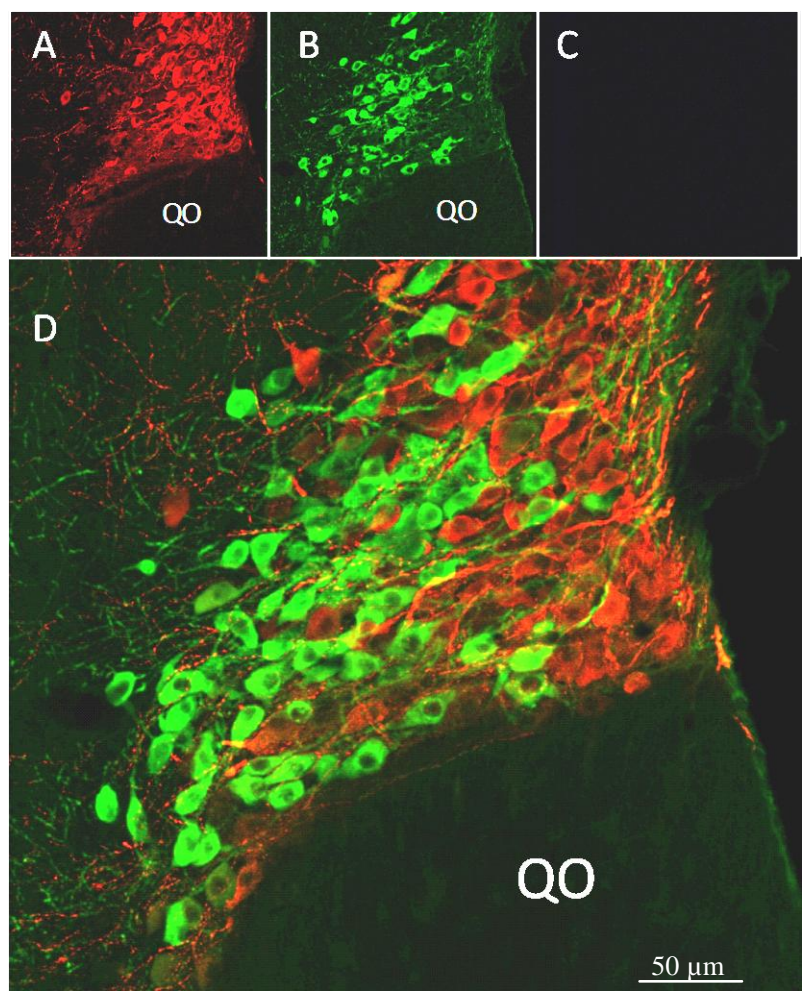

Figura 19. Imunofluorescência em fatias do SON. A, neurônios vasopressinérgicos marcados com anticorpo anti-VP (1:500 Guinea Pig anti-( $\left.\operatorname{Arg}^{8}\right)$-Vasopressina - Vermelho). B, neurônios marcado com anticorpo anti-OT (1:500 anti Rabbit - Verde). C, experimento controle somente com anticorpo secundário. Colocalização é mostrada em D. Note a ausência de colocalizações. QO = quiasma óptico.

Devido ao fato de não termos observado a mesma proporção de colocalizações na imunofluorescência com neurônios isolados e nas fatias, nós optamos por repetir a fluorescência na presença do DAF-FM e observar a produção de NO em fatias evitando assim alterações que possam ocorrer na fisiologia do neurônio durante o processo de dissociação. Os dados demonstram que durante o estimulo hipertônico ocorre um aumento na fluorescência indicando maior produção de NO que retorna aos níveis basais quando retiramos o estímulo. 
Por outro lado, na presença do inibidor da enzima sintase do óxido nítrico não observamos aumentos na produção de NO (Figura 20) confirmando a especificidade do estímulo.
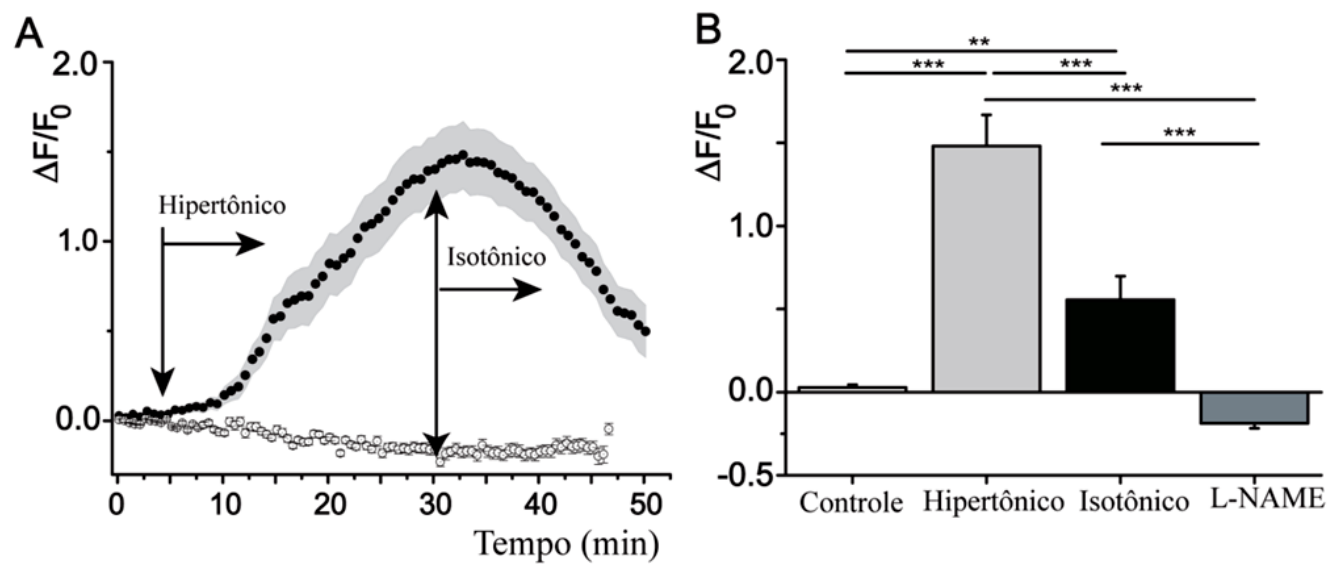

Figura 20. Hipertonicidade estimula a produção de NO nos neurônios magnocelulares do SON.

Em A, evolução temporal da produção do NO durante controle, o estímulo hipertônico e lavagem (círculos preenchidos) ou na presença do inibidor da sintase do óxido nítrico (círculos vazios). Durante o estímulo hipertônico houve um aumento da fluorescência e sua volta próximo aos níveis basais ocorreu com a lavagem, efeito não observado na presença do L-NAME. B resume os resultados obtidos em cada situação experimental. $\Delta \mathrm{F}=\left(\mathrm{F}-\mathrm{F}_{0}\right)$ é a diferença entre a fluorescência obtida em um intervalo de tempo $(\mathrm{F})$ e a fluorescência de fundo ("background") ( $\left.\mathrm{F}_{0}\right)$. A média dos valores foi calculada com os maiores valores de $\Delta \mathrm{F} / \mathrm{F}_{0}$ para cada situação.

Com esses experimentos nós evidenciamos que os neurônios magnocelulares são capazes de produzir óxido nítrico em resposta a aumentos da osmolalidade, e os neurônios isolados nos permitem inferir que esta produção ocorre independente das células gliais. Entretanto, uma vez que os neurônios magnocelulares são osmosensíveis, o aumento na produção de NO pode ser atribuído, em princípio, ao aumento da frequência de disparo dos neurônios ocasionada pelo estímulo hipertônico. Desta forma, para dissociar os dois fenômenos nós repetimos o experimento anterior, mas ao mesmo tempo um neurônio que estava carregado com o indicador fluorescente DAF-FM foi registrado, e quando o estímulo hipertônico foi aplicado, injeções de corrente negativa foram aplicadas com o intuito de hiperpolarizar o neurônio evitando assim que o mesmo aumentasse sua frequência de disparo. 
Desta forma, o neurônio permaneceu silente durante todo o estímulo. Como pode ser observado na figura 21 A e A1 o estímulo hipertônico novamente induziu um aumento na fluorescência, mesmo quando o neurônio estava silente. Estes resultados demonstram que o estímulo hipertônico por si só foi capaz de aumentar a produção de NO nos neurônios magnocelulares do núcleo supraóptico independentemente da frequência de disparo. Experimentos controles utilizando solução isotônica e despolarização do neurônio por injeção de corrente na ausência da hipertonicidade, também foram feitos e como demonstrado na figura 21 B, B1, C e C1 não houve alterações na fluorescência reforçando nossa hipótese de um efeito específico da hipertonicidade na produção de NO em neurônios magnocelulares do núcleo supraóptico.
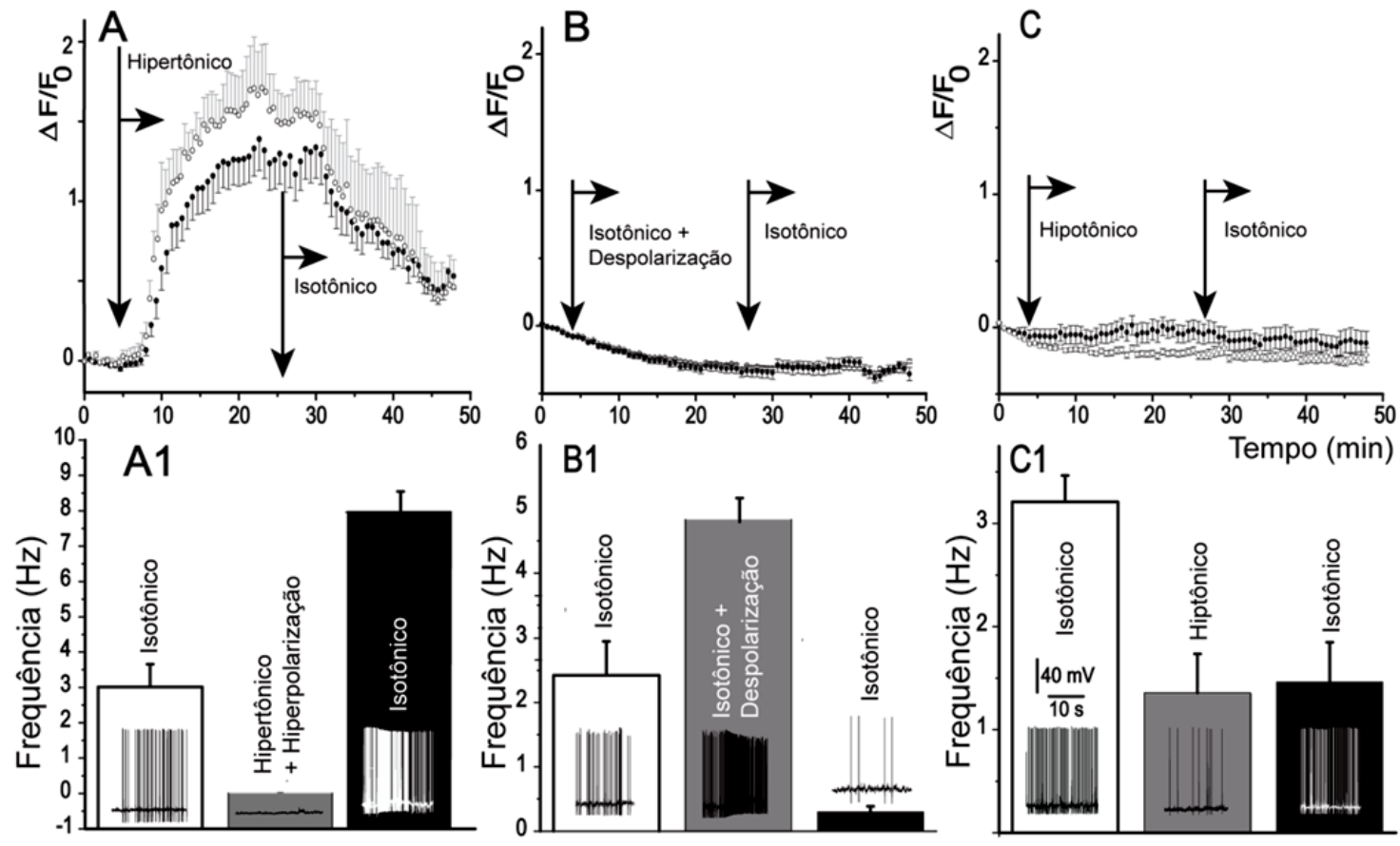

Figura 21. Frequência de disparo não determina a produção de NO. Frequência de disparo dos neurônios foi alterada por injeções de corrente hiperpolarizante (diminuição) ou despolarizante (aumento) em células submetidas a condições de tonicidade indicados em cada situação experimental. (A) Decurso temporal da produção de NO em condições isotônicas e em repouso, após exposição das células a hipertonicidade e hiperpolarização e ao voltar para isotonicidade, como indicado pelas setas. (B) Fluorescência medida sob condições isotônicas e despolarização da célula, a fim de aumentar a 
frequência de disparo. O painel (C) mostra uma situação em que as células foram expostas a hipotonicidade. A fluorescência das células registrada está representada pelos círculos abertos (A1, B1 $\mathrm{n}=7$ e $\mathbf{C 1} \mathrm{n}=8$ ) e as células vizinhas que serviram como controle positivo por círculos fechados (A1 n=32; B1 n=101 e C1 n=86). Os gráficos de barras resumem a frequência de disparo dos neurônios registrados para cada caso. Os traçados nos gráficos são representativos de cada situação e as escalas de voltagem e tempo mostradas em $\mathbf{C}$ são valida para todos os registros. Os dados foram expressos como média \pm epm.

Resumidamente, os resultados até aqui apresentados nos permitem duas conclusões: 1) Durante aumentos da osmolalidade, há um aumento na produção de NO nos neurônios magnocelulares do SON, sugerindo uma ação parácrina e/ou autócrina e 2) A modulação nitrérgica dos canais $\mathrm{HCN}$ nos neurônios magnocelulares do núcleo não envolve células gliais. Frente a estas evidências as seguintes perguntas foram feitas: 1) Qual isoforma dos canais HCN é expressa nos SON? 2) Qual a importância funcional destes canais nos MNCs?, e 3) Qual a via de sinalização utilizada pelo NO na modulação desses canais?

\subsection{Expressão dos Canais HCN por RT-qPCR Single Cell}

As quatro isoformas dos canais HCN já foram descritas no sistema nervoso central (71). Entretanto, no SON há uma controvérsia quanto à isoforma predominante $(96,102)$. Nesse sentido, nós inicialmente realizamos experimentos com "single cell RT-qPCR" para avaliarmos a isoforma dominante. De trinta neurônios analisados nós observamos que 17 expressaram mais de uma isoforma e 13 somente uma delas. Os fenótipos das mesmas células foram molecularmente identificados, mas não encontramos diferenças de expressão entre eles. Como podemos observar na tabela 3 , os MNCs vasopressinérgicos e ocitocinérgicos expressam RNAm para as quatro isoformas, sendo a do tipo 3 e 4 as predominantes. 


\begin{tabular}{|c|c|c|c|c|c|}
\hline \# Célula & HCN1 & $\mathrm{HCN} 2$ & $\mathrm{HCN} 3$ & $\mathrm{HCN} 4$ & Fenótipo \\
\hline 1 & & 0 & 0 & 0 & OT \\
\hline 2 & & & & 0 & VP \\
\hline 3 & & 0 & 0 & 0 & VP \\
\hline 4 & & & 0 & & VP \\
\hline 5 & & & 0 & & OT \\
\hline 6 & & 0 & & & VP \\
\hline 7 & & 0 & & 0 & VP \\
\hline 8 & & & 0 & & OT \\
\hline 9 & 0 & & & 0 & OT \\
\hline 10 & & & 0 & & OT \\
\hline 11 & 0 & & 0 & 0 & VP \\
\hline 12 & & & & 0 & VP \\
\hline 13 & 0 & & 0 & 0 & VP \\
\hline 14 & & 0 & & 0 & VP \\
\hline 15 & & & 0 & & VP \\
\hline 16 & & 0 & & 0 & VP \\
\hline 17 & & & 0 & 0 & VP \\
\hline 18 & & & & 0 & VP \\
\hline 19 & & & & 0 & OT \\
\hline 20 & & & 0 & 0 & IT \\
\hline 21 & 0 & & & 0 & OT \\
\hline 22 & 0 & & 0 & 0 & OT \\
\hline 23 & 0 & 0 & 0 & & OT \\
\hline 24 & & 0 & 0 & & IT \\
\hline 25 & & & & 0 & VP \\
\hline 26 & & 0 & & & VP \\
\hline 27 & & 0 & 0 & & VP \\
\hline 28 & & 0 & 0 & & IT \\
\hline 29 & & 0 & 0 & & VP \\
\hline 30 & & 0 & & & VP \\
\hline
\end{tabular}

Tabela 3. Expressão RNAm para isoformas dos canais HCN. Expressão dos canais HCN no supraóptico foi realizada por meio de single cell RT-qPCR. Neurônios vasopressinérgicos e ocitocinérgicos expressaram todas as isoformas, porém a do tipo 3 e 4 predominaram. Círculos coloridos indicam a expressão de uma determinada isoforma para cada célula analisada. Círculos Amarelos $=$ HCN1, Vermelhos $=$ HCN2, Verdes $=$ HCN3 e Azuis $=$ HCN4.

\subsection{Efeitos Macroscópicos do ZD7288}

Estudos electrofisiológicos demonstraram que os canais HCN são responsáveis por manter o nível do potencial de repouso em vários tipos de neurônios (43, 50, 125). Desta forma, para avaliarmos o papel funcional dos canais $\mathrm{HCN}$ na excitabilidade dos MNCs, registramos a atividade intrínseca dos neurônios magnocelulares em condição controle e na 
presença do ZD7288, bloqueador desses canais. Como demonstrado na figura $22 \mathrm{~A}, \mathrm{~B}$ e C, houve uma redução significativa na frequência de disparo dos neurônios quando o ZD7288 foi adicionado à solução de perfusão $(4,3 \pm 0,5 \mathrm{~Hz}$ vs $2,7 \pm 0,4 \mathrm{~Hz}, \mathrm{n}=13 ; \mathrm{p}<0,05)$, demonstrando uma participação destes na excitabilidade dos MNCs. Adicionalmente, o número de potenciais de ação em resposta a valores crescentes de correntes positivas foi reduzido na presença do ZD7288 quando comparamos com o grupo controle $(73,7 \pm 2,4$ vs $64,1 \pm 2,9$ $\mathrm{n}=12 ; \mathrm{p}<0,05)$, mais uma vez, demonstrando uma redução da excitabilidade dos neurônios (Figura 22 E e E1). Por outro lado, a resposta dos neurônios a injeções de corrente negativa (Figura 22 D) mostrou que a resistência de entrada dos mesmos, não foi estatisticamente diferente entre os grupos $($ Controle $=1,1 \pm 0,5 \mathrm{G} \Omega$ vs $\mathrm{ZD} 7288=1,0 \pm 0,4 \mathrm{G} \Omega, \mathrm{n}=12$; $\mathrm{p}>0,05)$. 

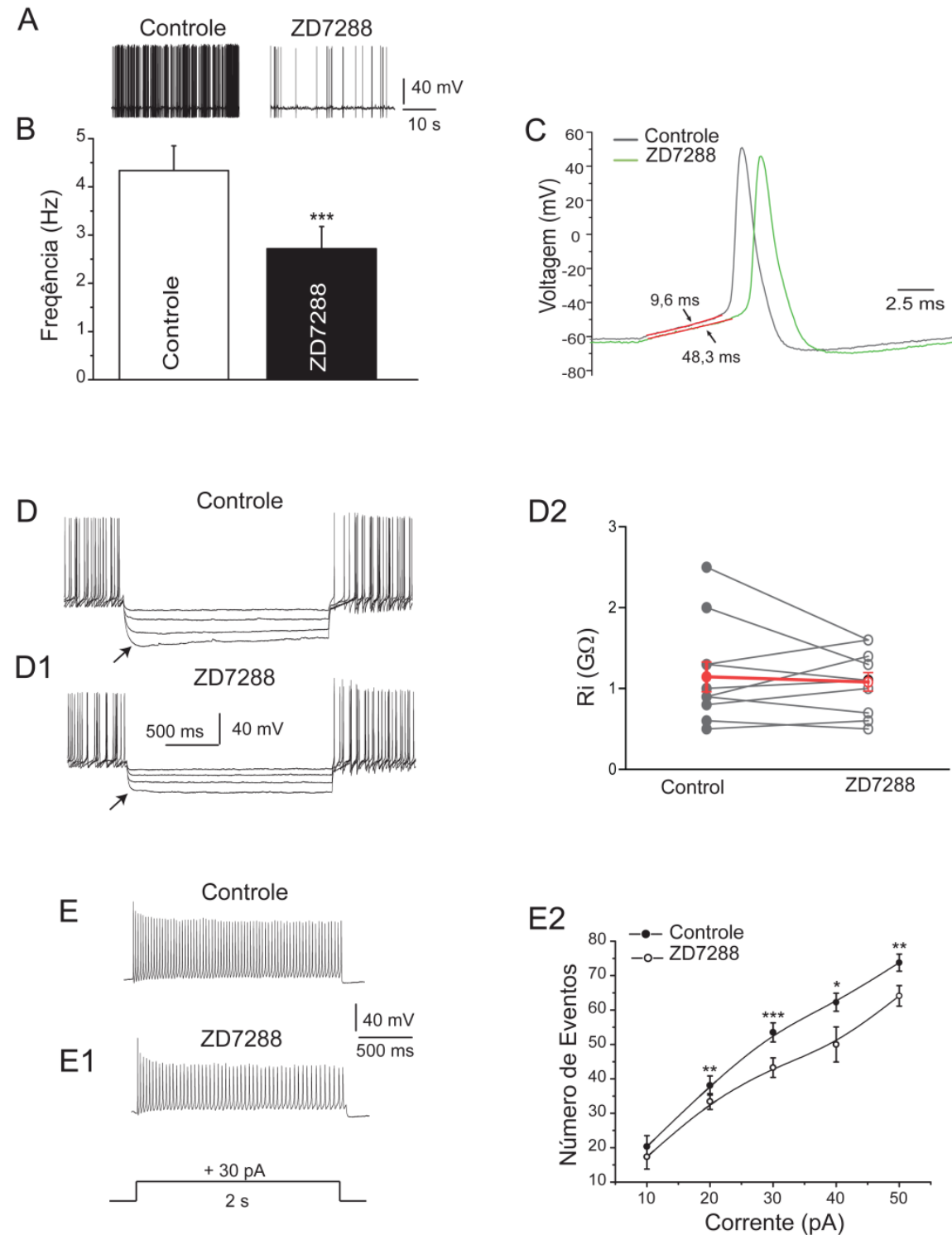

Figura 22. Canais HCN contribuem para excitabilidade dos neurônios do SON. Traçado representativo de um neurônio do grupo ilustrando os feitos do ZD7288 na frequência de disparo dos MNCs e no número de potenciais durante injeções de corrente positiva (A, E e E1). Em $\mathbf{C}$, o mesmo traçado exposto em A, ampliado para visualizar melhor os efeitos do ZD7288 na cinética do potencial de ação. A linha vermelha representa o ajuste de uma exponencial simples na fase de despolarização pós-potencial, e como demonstrado o ZD parece reduzir a constante de tempo deste processo. Os gráficos em $\mathbf{B}$ e $\mathbf{E} 2$ resumem a média \pm epm de 12 neurônios registrados. Como demonstrado em $\mathbf{D}$, D1 e D2 a resistência de entrada dos neurônios, medida por injeções de corrente negativa (0 a -50 pA) não foi significativamente alterada na presença do ZD quando comparado ao controle. 


\subsection{Vias de Sinalização do NO}

Como os canais HCN possuem sítios de ligação para cGMP, e este por sua vez, tem sido apontado na literatura como principal via de sinalização do NO, avaliamos se o mecanismo de modulação nitrérgica nesses canais, envolve a formação deste segundo mensageiro. Para tanto, utilizamos um inibidor seletivo da guanilato ciclase solúvel, H-(1,2,4) oxadiazolo[4,3-a] quinoxalin-1-one - ODQ $(10 \mu \mathrm{M}, 30 \mu \mathrm{M}$ e $100 \mu \mathrm{M})$, mas nenhuma alteração e evidência significativa de modulação endógena do NO utilizando essa via de sinalização foi observado (Figura 23). Também não observamos diferenças de modulação em relação ao fenótipo celular caracterizado pelo RT-qPCR em célula única.
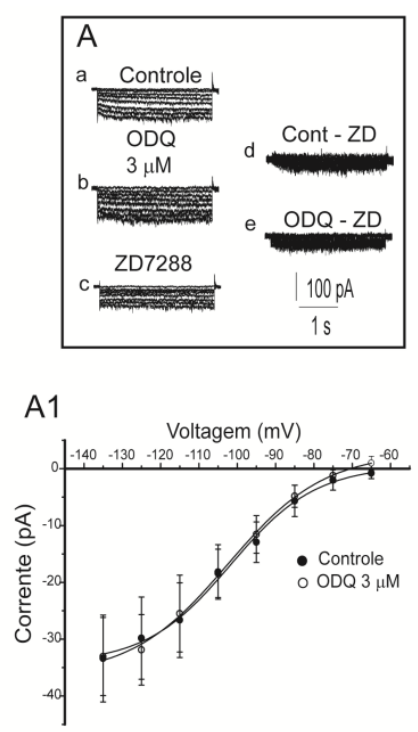
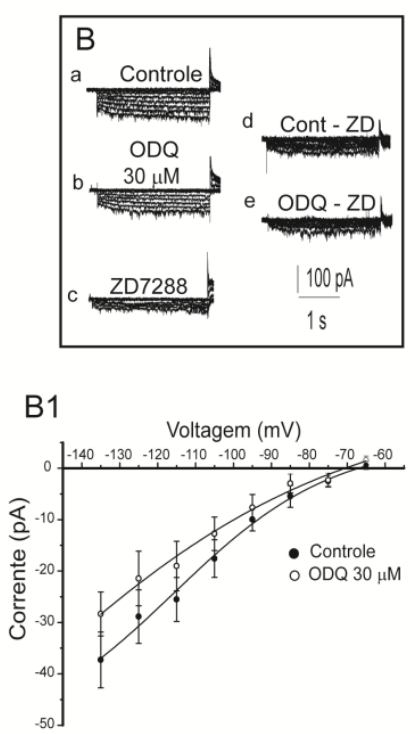
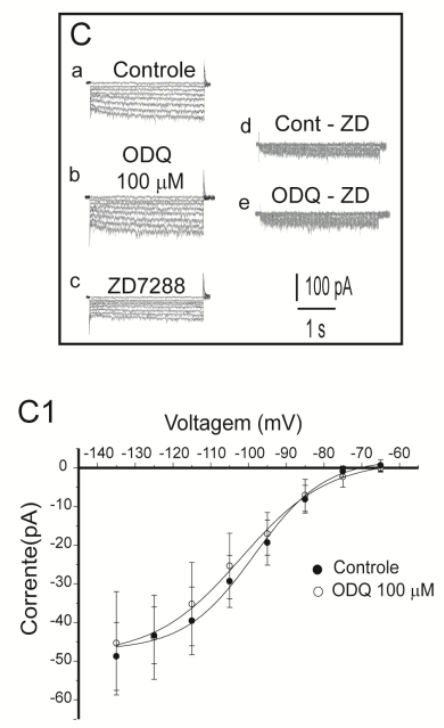

Figura 23. Modulação nitrérgica nos canais HCN é independente de cGMP. A, B e C representam traçados de corrente evocados por pulsos de voltagem de -50 a $-135 \mathrm{mV}$, com duração de 3 segundos, na presença de três concentrações distintas do inibidor da guanilato ciclase solúvel (ODQ $3 \mu \mathrm{M}, 30$ $\mu \mathrm{M}$ e $100 \mu \mathrm{M})$, seguido do inibidor da corrente $\mathrm{I}_{\mathrm{h}}$, ZD7288 $(50 \mu \mathrm{M})$. Correntes $\mathrm{I}_{\mathrm{h}}$ obtidas pela subtração digital (d,e). A1, B1 e C1 relação corrente x voltagem para o componente sensível a ZD7288. Não foi observado alterações significativas na corrente $I_{h}$ em nenhuma das concentrações utilizadas. Controle $v s$ ODQ: $3 \mu \mathrm{M}(-33,3 \pm 7,6 \mathrm{pA} v s 33 \pm 6,8 \mathrm{pA}), 30 \mu \mathrm{M}(30,6 \pm 4 \mathrm{pA} v s-37,2 \pm$ $5,4 \mathrm{pA})$ e $100 \mu \mathrm{M}(-48,7 \pm 8,7 \mathrm{pA} v s-45,3 \pm 13,3 \mathrm{pA}) . \mathrm{p}>0,05$ para todas as concentrações. Oito células foram registradas para cada concentração utilizada. 
A partir desses resultados, utilizamos a concentração intermediária de ODQ (30 $\mu \mathrm{M})$ testada anteriormente, e acrescentamos à solução de perfusão o substrato do NO, L-arginina. Como demonstrado na figura 24 , observamos que mesmo na presença do inibidor da guanilato ciclase, a L-arginina foi capaz de reduzir significativamente a corrente $\mathrm{I}_{\mathrm{h}}$, tanto em neurônios VP quanto OT, apontando, assim, uma via direta de modulação ou o envolvimento de outros segundos mensageiros, ainda desconhecidos.
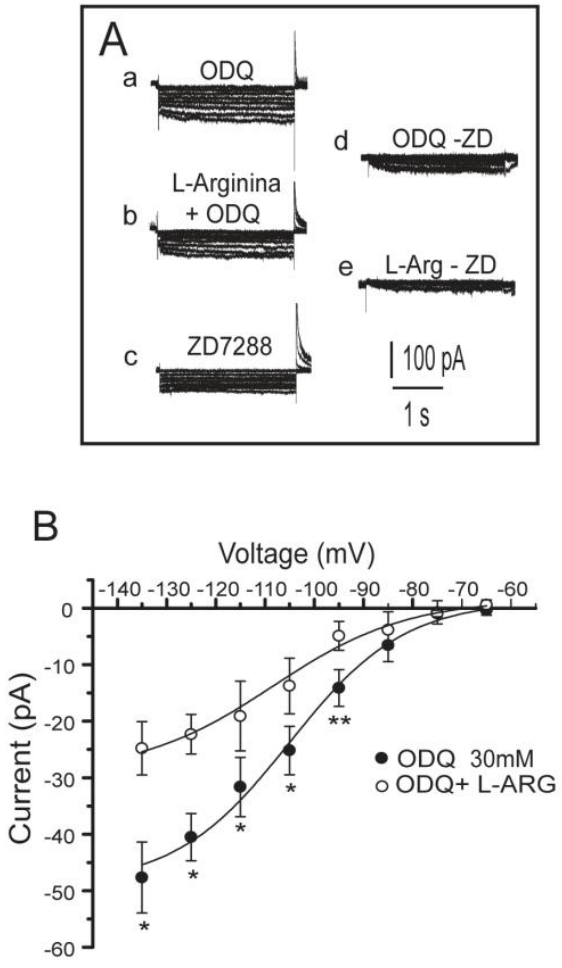

Figura 24. Modulação nitrérgica dos canais HCN é independente de cGMP. A relação $I-V$ foi construída utilizando-se o mesmo protocolo descrito anteriormente e demonstra o efeito da L-arginina na presença do inibidor da guanilato ciclase. Mesmo na presença do bloqueador a L-arginina reduziu significativamente a corrente $I_{h}$ sugerindo uma via independente de cGMP. $(-48 \pm 14$ pA x $-24,7 \pm 10$ $\mathrm{pA}, \mathrm{n}=5) . * \mathrm{p}<0,05-$ Teste $\mathrm{t}$ pareado. 


\subsection{2 Óxido Nítrico Modula os Canais HCN por Mecanismo de S-nitrosilação}

A visão clássica de que o cGMP é o único mediador da modulação nitrérgica tem sido questionada nos últimos anos. Uma nova via de modulação, a S-nitrosilação, tem sido proposta como via alternativa (3). A S-nitrosilação é um mecanismo importante para estabilizar a reação do NO, prolongando sua atividade biológica, e tem sido apontada como uma modificação pós-traducional chave em canais iônicos (60) incluindo os HCN (155). Diante disso, além de investigarmos o envolvimento do cGMP na modulação nitrérgica, também investigamos se essa modulação ocorre por este mecanismos não convencional. Para tanto, utilizamos a técnica de patch clamp em modo voltage clamp para aplicação de pulsos de voltagem hiperpolarizantes $(-50 \mathrm{a}-135 \mathrm{mV})$ a partir de um pulso pré-condicionado de -50 mV. A corrente foi registrada numa condição controle, na presença de L-arginina e na presença de ZD7288 mais L-arginina, como nos registro anteriores expostos acima. Porém, neste caso, utilizamos um bloqueador, a N-etilmaleimida (NEM - $300 \mu \mathrm{M}$ ), que oxida os resíduos de cisteína impedindo a S-nitrosilação. A figura 25 mostra os resultados obtidos em 11 neurônios magnocelulares na presença do inibidor da S-nitrosilação. Como podemos observar, quando os resíduos de cisteína são oxidados há um aumento na corrente $\mathrm{I}_{\mathrm{h}}$ demonstrando que este processo pode ser uma via de modulação dos canais $\operatorname{HCN}(-33,2 \pm 10$ pA vs 81,2 $\pm 13 \mathrm{pA}$ em $-135 \mathrm{mV}$, controle e nitrosilado respectivamente, $\mathrm{n}=11 ; \mathrm{p}<0,05)$. De fato, quando a L-arginina foi adicionada ao banho não foi observado redução na corrente $I_{h}(-$ $59,2 \pm 15$ pA $v s-59 \pm 11$ pA em $-135 \mathrm{mV} ; \mathrm{n}=10 ; \mathrm{p}>0,05)$, como demonstrado previamente por nós (130), permitindo concluir que os canais $\mathrm{HCN}$ podem ser S-nitrosilados (Figura 25 B). 

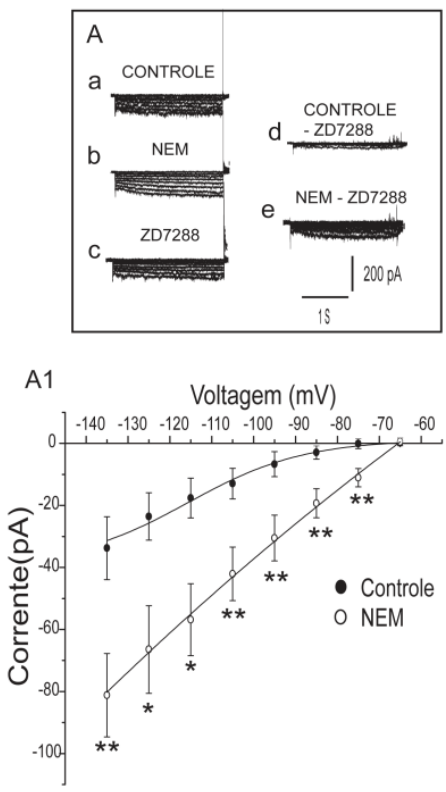
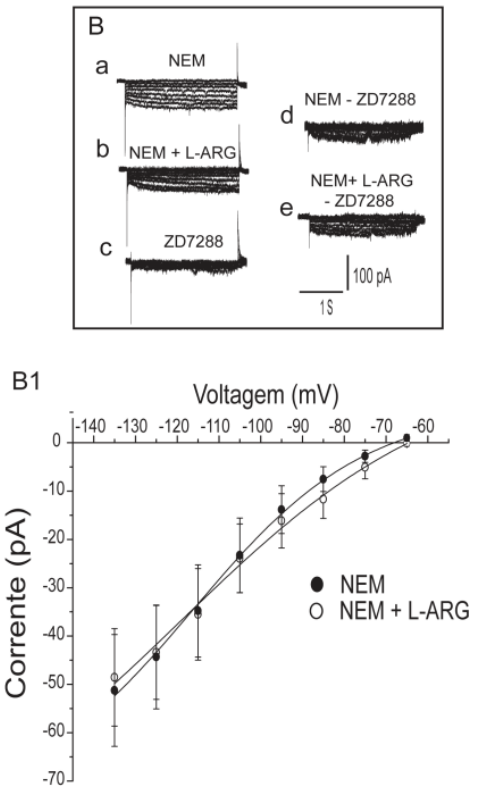

Figura 25. Modulação nitrérgica dos canais $\mathrm{HCN}$ é dependente de s-nitrosilação. Em A e B, traçados representativos de registros de corrente $I_{h}$ na presença do bloqueador NEM, NEM + Larginina seguido de ZD7288. Gráfico $\mathbf{A 1}$ mostra a relação $I-V$ da média de neurônios registrados na presença do bloqueador da S-nitrosilação (NEM - $300 \mu \mathrm{M})$. Note que na presença do bloqueador houve um aumento na corrente basal indicando que o canal é modulado por oxidações dos resíduos de cisteína $(-33,2 \pm 10$ pA vs 81,2 \pm 13 pA em $-135 \mathrm{mV}$, controle e nitrosilado respectivamente, $\mathrm{n}=11$; p $<0,05)$. Em B1, o gráfico com a relação $I-V$ resume a média dos neurônios registrados na presença da L-arginina demonstrando que na presença do bloqueador da S-nitrosilação a L-arginina não foi capaz de alterar a corrente $I_{h}$ apontando a via utilizada pelo NO para modular os canais HCN $(-59,2 \pm 15$ pA $v s-59 \pm 11$ pA em $-135 \mathrm{mV} ; \mathrm{n}=10 ; \mathrm{p}>0,05)$. Não foi observado diferenças entre os fenótipos celulares.

Apesar da N-ethylmaleimide ser um oxidante específico para resíduos de cisteina, testamos, ainda, o ácido ascórbico, que também atua como um agente denitrosilante ou redutor (138). Como demonstrado na figura 26, na presença do ácido ascórbico há um aumento na magnitude da corrente $(-9,8 \pm 14$ vs $-16,8 \pm 8,5, \mathrm{n}=6 ; \mathrm{p}<0,05)$ sugerindo a presença de uma S-nitrosilação endógena. 
A
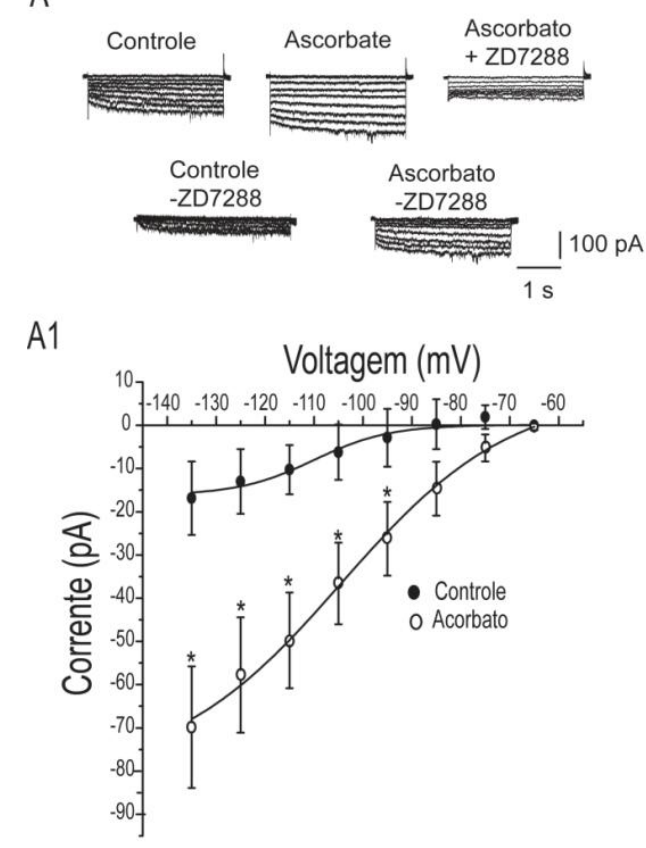

Figura 26. Neurônios magnocelulares são s-nitrosilados endogenamente. $\mathrm{O}$ gráfico $I-V$ mostra o efeito da denitrosilação nos canais HCN. Como podemos observar, na presença do ascorbato houve um aumento na magnitude da corrente $\mathrm{I}_{\mathrm{h}}$ indicando uma s-nitrosilação endógena $(-9,8 \pm 14$ vs $-16,8 \pm$ $8,5, \mathrm{n}=6 ; \mathrm{p}<0,05)$. Não foi observado diferenças entre os fenótipos celulares.

\subsection{Modulações Nitrérgica dos Canais HCN Durante Estimulo Hipertônico} Agudo

Partindo do principio que a produção e liberação de VP e OT na circulação sistêmica são modificadas toda vez que ocorrem alterações na osmolalidade plasmática, e que o estímulo osmótico aumenta a produção do NO, nós também avaliamos o se estimulo hipertônico per se modulava os canais $\mathrm{HCN}$. Como ilustrado na figura 27, a corrente $\mathrm{I}_{\mathrm{h}}$ na presença da solução hipertônica $\left(330 \mathrm{mosm} / \mathrm{kg} . \mathrm{H}_{2} \mathrm{O}\right)$ teve um valor médio de $-50,33 \pm 0,9$ pA, (em -135 mV) significativamente maior que na situação controle $(-20,1 \pm 7$ pA, em -135 $\mathrm{mV})$. Observamos ainda, que na presença do bloqueador da NOS, um aumento adicional foi observado demonstrando que o NO produzido nessas condições experimentais tem também um efeito inibitório sobre os canais HCN (Figura 27 B e D). 

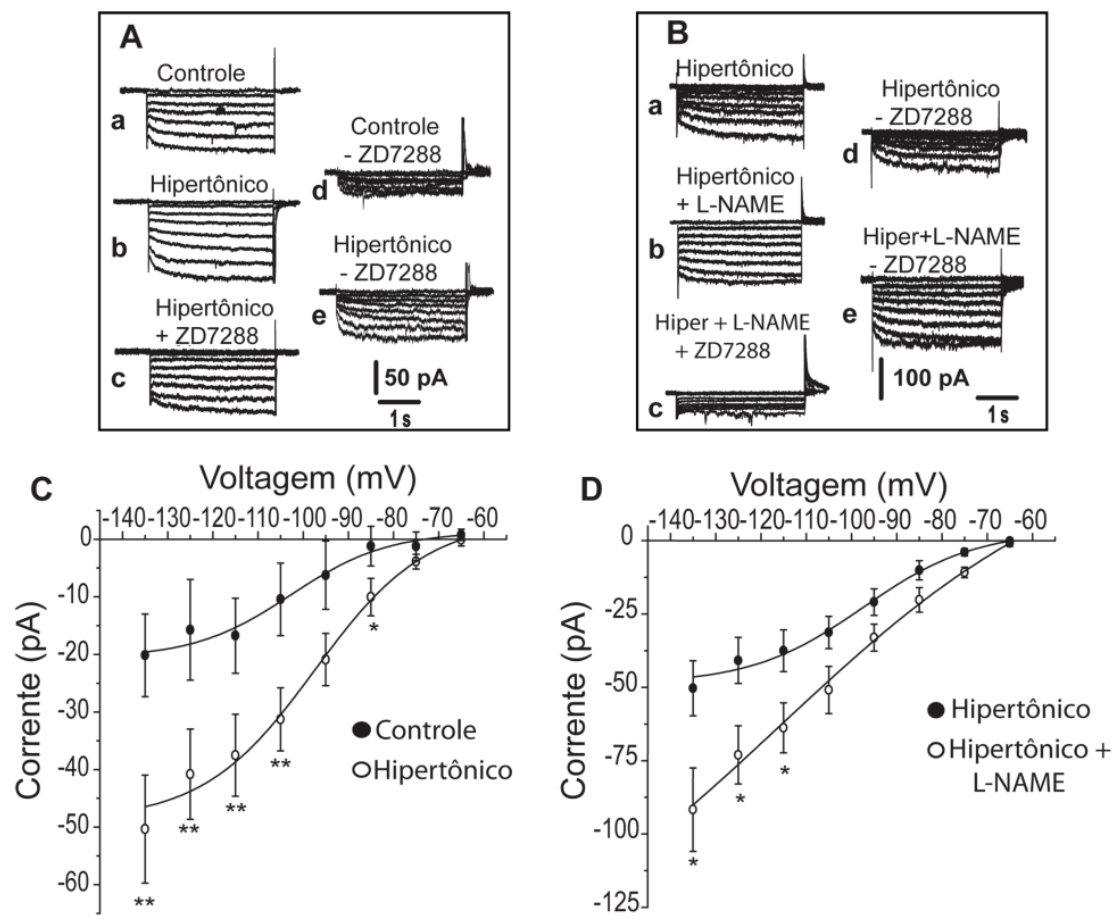

Figura 27. Hipertonicidade modula os canais HCN em neurônios magnocelulares. Em A e B, traçados típicos obtidos de um neurônio do grupo na condição controle (a), na presença do estímulo hipertônico (b) ou hipertônico mais L-NAME (B-b), seguido da aplicação do bloqueador dos canais HCN ZD7288 (c). d,e representam o componente sensível ao ZD7288 em cada condição experimental. C e D, as relações I-V das médias das correntes sensíveis ao ZD7288 (corrente $\mathrm{I}_{\mathrm{h}}$ ) nas mesmas condições experimentais descritas acima. Note um aumento significativo da corrente $\mathrm{I}_{\mathrm{h}}$ na presença do estímulo hipertônico quando comparado ao controle (-50,33 $\pm 0,9$ pA vs 20,1 \pm 7 pA, n=9), e um aumento adicional na corrente quando o L-NAME foi adicionado ao banho $(-91.7 \pm 14$ vs $-50,33 \pm$ $0,9)$. Diferenças estatísticas estão indicar por * $(* \mathrm{p}<0,05 ; * * \mathrm{p}<0,005)$. Não foi observado diferenças entre os fenótipos celulares. 


\section{DISCUSSÃO}

No presente trabalho, nós investigamos os possíveis mecanismos da modulação nitrérgica sobre os canais $\mathrm{HCN}$ bem como a origem deste neuromodulador. Até o momento demonstramos que o NO produzido nos neurônios magnocelulares do SON, modula a corrente $\mathrm{I}_{\mathrm{h}}$ independentemente de cGMP, não envolve outros tipos de células nesta resposta e não há diferenças na modulação quanto ao fenótipo celular. Além disso, experimentos investigando mecanismos não convencionais de modulação como a S-nitrosilação mostram a presença de uma via de sinalização alternativa do NO. Evidenciamos ainda que aumentos da osmolalidade promoveram um aumento significativo da corrente $\mathrm{I}_{\mathrm{h}}$, mostrando que os canais HCN também são modulados pelo estresse osmótico, e que o NO produzido nessas condições, tem um efeito inibitório sobre os canais HCN. Destacamos ainda a importância de se diferenciar os fenótipos dos neurônios magnocelulares, bem como a sensibilidade de alguns métodos que são utilizados para este fim.

Como a excitabilidade dos MNCs está diretamente relacionada com a quantidade de neuropeptídios liberados $(40,107)$, entender os mecanismos que a controlam implica em contribuir para o melhor entendimento da sua fisiologia. Dentre os mecanismos já descritos na literatura, o controle sináptico é um deles, e sua contribuição está relacionada ao balanço entre as entradas excitatórias e inibitórias, mediadas pelos neurotransmissores glutamatérgicos e GABAérgicos, respectivamente $(37,41)$. No entanto, outros fatores também podem alterar a excitabilidade destes neurônios independentemente da transmissão sináptica. Um deles é a alteração da osmolalidade plasmática, que aumenta ou reduz a excitabilidade neuronal com consequentes alterações na concentração de vasopressina e ocitocina circulante (24). Adicionalmente, tem sido demonstrado que tanto em condições isotônicas quanto durante alterações na osmolalidade plasmática, alguns neuromoduladores são capazes de, direta ou 
indiretamente, controlar a excitabilidade dos MNCs $(133,136)$. Dentre estes o NO tem se mostrado um modulador da excitabilidade destes neurônios tanto via sinapse (141) quanto por ações diretas em canais iônicos (130).

\subsection{Caracterização Fenotípica Baseada no Método Eletrofisiológico}

Tao importante quanto desvendar os mecanismos de ação do NO em neurônios do SON, é realizar a caracterização adequada do fenótipo celular. Este parâmetro é importante no entendimento da fisiologia dos MNCs uma vez que nossos resultados e de outros tem mostrado que uma mesma molécula pode ter efeitos distintos dependendo do fenótipo celular $(62,120,165)$. Eletrofisiologicamente, neurônios VP e OT podem ser distinguidos uns dos outros por vários procedimentos. No entanto, a maior parte dos métodos é baseada na resposta dos neurônios a um determinado peptídeo ou, por exemplo, pela sucção durante a amamentação $(7,54,118)$, tornando o processo de diferenciação fenotípica complexo. Outra complicação na diferenciação dos MNCs, baseado apenas na eletrofisiologia surgiu com os estudos de Moos et al (97). Os autores demonstraram que durante a amamentação, alguns neurônios exibiam tanto características fásicas da vasopressina quando atividades em burst da ocitocina, características utilizadas para diferenciar os fenótipos na década de 70 a 80 (24, 119, 160). Esta constatação aumentou a possibilidade de que ambos os peptídeos poderiam ser sintetizados na mesma célula. No entanto, a descoberta das correntes retificadoras, supostamente expressa em OT, mas não em neurônios VP $(8,61,139,165)$ tem sido utilizado como critério para distinguir os fenótipos. Como já sugerido acima, este protocolo está sujeito a criticas, uma vez que os neurônios deste núcleo possuem três fenótipos: 1) Vasopressinérgico, caracterizado pela síntese de vasopressina; 2) ocitocinérgico, caracterizado pela síntese de ocitocina; e 3) um terceiro tipo, no qual VP e OT são sintetizados em concentrações equivalentes e são denominados de intermediários $(52,74,94)$. 
Neste estudo, observamos que de 63 neurônios caracterizados como ocitocinérgicos pela eletrofisiologia, 36 foram identificados como vasopressinérgicos pelo RT-qPCR (Figura 11), evidenciando que o protocolo eletrofisiológico não se coaduna com os resultados obtidos pela biologia molecular. Portanto, os nossos resultados indicam que a presença ou ausência de correntes retificadoras na relação $I-V$ não são parâmetros confiáveis para serem utilizados como identificadores de fenótipos dos MNCs. Nossos dados corroboram os de Zampronio et al. (165) que utilizaram ratos transgênicos expressando eGFP, juntamente com o gene da vasopressina, e observaram que nem todos os neurônios identificados como ocitocinérgicos, devido à ausência de eGFP, apresentavam correntes retificadoras. Esses achados reforçam a ideia de que este tipo de corrente não se restringe aos neurônios OT. Além disso, os neurônios que expressam ambos os peptídeos, conforme indicado por imunofluorescência, não foram incluídos no grupo de neurônios por eles analisados.

Desta forma, os resultados divergentes aqui relatados podem ser atribuídos a 2 fatores: 1) a presença de correntes retificadoras em células vasopressinérgicas e intermediárias, e 2) devido ao fato da primeira descrição do uso das correntes retificadoras e sua correlação com os neurônios ocitocinérgicos (mas não os seguintes, ver Hirasawa et al., 2003 e Zampronio et al., 2010 ) terem utilizado eletrodos finos, com duração das injeções de corrente 6 vezes maior do que em experimentos de patch clamp $(8,139,140)$. De fato, estudos comparando experimentos realizados com registros intracelulares através de microeletrodos finos e whole cell patch clamp, mostraram que devido a grande corrente de vazamento na interface eletrodo/membrana, observada nos experimentos com eletrodos, a propriedade intrínseca dos neurônios pode mostrar-se alterada levando, por exemplo, a despolarização do potencial de repouso $(82,137)$. Além disso, estudo mais recente de Li e colaboradores (80) reporta que foram incapazes de replicar os resultados do protocolo eletrofisiológico porque o mesmo não era consistente com registros em whole cell. 


\subsubsection{Tripla Caracterização dos MNCs}

Apear da expressão de RNAm ter sido correlacionada e utilizada como estimativa da síntese de proteína/peptídeo, a correlação entre eles ainda é um assunto controverso e os resultados descritos até agora têm sido relativamente inconsistentes. Coeficientes altos e baixos entre os dois parâmetros foram relatados para as proteínas, variando de 0,40 a 0,78 (55, 56, 88), e uma alta correlação para peptídeos (101). Frente a esse impasse, e com o intuito de evitar erros na caracterização fenotípica somente pela expressão de RNAm, foi realizada uma caracterização tripla em um único neurônio, comparando os resultados eletrofisiológicos não apenas com RT- qPCR, mas também com imunofluorescência (ver métodos 3.5). Como mostram a figura 12 e tabela 2, há uma forte correlação entre o fenótipo caracterizado pela imunofluorescência e RT - qPCR. Comparando os resultados obtidos pelos três métodos, observou-se que apenas 10 neurônios identificados pela eletrofisiologia corresponderam aos descritos pela imunofluorescência, e apenas 8 com imunofluorescência e RT- qPCR (Tabela 2). Este fato é particularmente crítico se consideramos situações em que a proporção relativa dos tipos neuronais está alterada.

Como demonstrado, a expressão de RNAm obtido pelo RT-qPCR teve uma correlação de $80 \%$ com a imunofluorescência. Contudo, os resultados do protocolo eletrofisiológico não corroboraram aqueles obtidos com imunofluorescência, reforçando a hipótese de que o critério da presença ou ausência de correntes retificadoras em neurônios magnocelulares ocitocinérgicos e vasopressinérgicos, respectivamente, não é determinante para distinguir o fenótipo dos mesmos.

\subsubsection{Implicações Fisiológicas}

O número de neurônios com fenótipo intermediário encontrado na caracterização pelo RT - qPCR (n=18) não nos surpreendeu, uma vez que $1 \%$ - $3 \%$ dos MNCs co-expressam 
ambos os peptídeos sob condições fisiológicas. Além disso, quando o sistema é confrontado com situações de desafio, como lactação, esta percentagem pode aumentar para $24 \%$, e ambos os peptídeos podem ser encontrados na mesma vesícula neurossecretora. Sob estas condições, Mezey et al (94) sugeriram que os neurônios OT expressando pouca ou nenhuma VP se tornam capazes de sintetizar VP de modo a compensar a perda de água observada durante a lactação. Nossos resultados reforçam esta hipótese, uma vez que ratos submetidos à restrição hídrica mostraram um aumento nos neurônios imunorreativos a VP e uma diminuição no número relativo de neurônios OT (Figura 15). Esta é uma clara indicação de que os neurônios são capazes de alterar seu fenótipo em resposta a uma situação de desafio.

Este fenômeno pode ser explicado, pelo menos em parte, por dois fatores: 1) a presença de RNAm de OT e VP na mesma célula, permitindo que os neurônios sintetizem ambos ou apenas um dos peptídeos quando necessário (através de uma regulação pós-transcricional do RNAm), e/ou 2) por modulações dos genes envolvidos na expressão da OT e VP. Estas hipóteses estão apoiadas por estudos de hibridização in situ e RT-qPCR, confirmando a expressão de ambos os RNAs mensageiros na maioria dos MNCs, com um aumento evidente em um deles, quando o sistema é osmoticamente estressado (52, 73, 92, 159). A coexistência de ambos RNAm (s) parece ser uma propriedade de neurônios magnocelulares, uma vez que neurônios magnocelulares do núcleo paraventricular lateral também expressam RNAm para VP e OT (Figura 14), enquanto os neurônios vasopressinérgicos parvocelulares do núcleo supraquiasmático não expressam RNAm para OT (52). Em relação à modulação gênica, dados da literatura mostram que os genes que codificam VP e OT estão no mesmo cromossomo separados apenas por uma região intergênica, e são processados em sentidos de transcrição opostos $(57,95)$. O que se sabe ainda é que a identidade molecular fenotípica desses neurônios é regulada por genes específicos, e o consenso é que entre o domínio 288 pb e 116 pb exista um ativador específico para VP e um repressor que inibe a expressão de OT 
nos MNCs, levando assim a expressão de um único peptídeo (117). No entanto, vários estudos têm demonstrado que a expressão de genes VP e OT pode ser influenciada por entradas sinápticas, bem como por estímulos osmóticos $(10,46,92,99)$.

Não foram observadas mudanças significativas na proporção de neurônios VP e OT em ratos com sobrecarga salina em comparação com o controle. Se considerarmos que neste modelo alterações na diurese e natriurese (Liberação de peptídeo atrial natriurético, inibição do transporte de $\mathrm{Na}^{+}$, supressão da liberação de renina, inibição da liberação de aldosterona, e aumento na liberação de ocitocina e vasopressina), são necessárias, é fácil entendermos porque não encontramos alterações na proporção relativa de fenótipos nesta situação $(23,63$, $132,148,149)$.

Assim devido à alta especificidade oferecida pelo RT-PCR e sua alta correlação com a imunofluorescência, podemos dizer que o método eletrofisiológico utilizado para caracterizar o fenótipo dos neurônios magnocelulares do SON não é confiável quando usado isoladamente e em Whole cell patch clamp. Neste estudo a caracterização fenotípica foi realizada utilizando o RT-qPCR.

\subsection{Células Gliais e Óxido Nítrico}

Em condições experimentais que resultam em remodelamento da interação neurônio glia, um ponto importante a ser considerado é que a excitabilidade celular pode estar alterada, uma vez que a recaptação de glutamato da fenda sináptica esta comprometida. Neste sentido, o acúmulo deste neurotransmissor altera a atividade neuronal por reduzir a eficácia sináptica por meio da ativação de receptores metabotrópicos glutamatérgicos (112). No SON esta alteração na recaptação resulta em ativação de receptores metabotrópicos do tipo III gliais, os quais estão negativamente acoplados à liberação de neurotransmissores (14, 110). Apesar de não termos observado envolvimento das células gliais na modulação nitrérgica com o uso do 
fluorocitrato, nossos resultados mostram diferenças significativas com o protocolo de sobrecarga salina, onde a L-arginina promoveu duas respostas distintas: um aumento, e uma redução na frequência de potenciais de ação. Com relação ao L-NAME, nós observamos que em todos os neurônios analisados o L-NAME produziu um aumento na frequência de potenciais de ação (Figuras 6 e 7). Desta forma, seria razoável pensar que os efeitos observados foram devidos às alterações no "clearance" de glutamato e não do NO. Todavia, como nossos experimentos foram realizados na presença de bloqueadores glutamatérgicos e GABAérgicos, nós descartamos esta possibilidade. Além disso, separando os neurônios de acordo com seu fenótipo, observou-se que aqueles que apresentaram uma redução na frequência de potenciais de ação foram molecularmente caracterizados como vasopressinérgicos, enquanto que os neurônios que apresentaram um aumento neste parâmetro foram caracterizados como ocitocinérgicos. Estes resultados reafirmam o fato de que uma determinada droga pode ocasionar diferentes efeitos dependendo do fenótipo do neurônio $(62,165)$ e da condição experimental (136). Adicionalmente, algumas moléculas podem, ainda, ocasionar efeitos diferentes em neurônios com mesmo fenótipo (120). Por outro lado, olhando para o modelo experimental utilizado, é importante lembrar que a sobrecarga salina apesar de ocasionar retração glial, ela também ocasiona alterações sistêmicas por acarretar um aumento na concentração de sódio circulante (neste estudo, a média foi de $168 \mathrm{mEq} \pm 10$ ), bem como a anorexia adaptativa induzida por alterações osmóticas (154). Neste sentido, o modelo de sobrecarga salina pode estar sujeito a críticas quando utilizado para esta análise.

Não constatamos participação das células gliais na modulação nitrérgica dos canais HCN uma vez que reduções significativas da corrente estacionária dos canais HCN foram observadas na presença da L-arginina, em neurônios isolados (Figura 16). Assim, descartamos 
os efeitos do remodelamento glial nesta resposta e a participação dessas células na modulação nitrérgica nos canais $\mathrm{HCN}$.

\subsection{Excitabilidade Neuronal e Canais HCN}

No sistema nervoso central estudos demonstraram que a maioria dos neurônios expressa uma ou mais isoformas dos canais HCN. Ao contrário da grande maioria dos canais iônicos, os HCN são ativados por hiperpolarização da membrana (152) e responsáveis por originar uma corrente conhecida como $\mathrm{I}_{\mathrm{h}}$. Uma corrente mista, para sódio e potássio, com uma razão de permeabilidade de aproximadamente 1:4, sendo bloqueada por concentrações milimolares de $\mathrm{Cs}^{+}(152)$ e mais seletivamente por um agente bradicárdico, o ZD7288 (4-(N-ethyl-Nphenylamino)-1,2-dimethyl-6-(methylamino) pyrimidinium chloride) (158). Quatro isoformas dos canais HCN já foram identificadas (13). Entretanto no SON, os dados descritos até o momento são controversos $(96,102)$. Neste estudo, nós mostramos que a maioria dos neurônios expressaram RNAm de todas as isoformas dos canais, com predominância do tipo 3 e 4. Estes resultados corroboram dados de Monteggia et al. (96) mas não os de Notomi e colaboradores (102) que observaram uma predominância das isoformas 2 e 3 (Tabela 3). Somente 6 neurônios, de um total de 30 analisados, expressaram a isoforma do tipo 1, embora a literatura sugira que esta isoforma seja expressa seletivamente em alguns tipos celulares como células do hipocampo, Purkinje e cerebelo (124). O fato de encontrarmos RNAm para todas as isoformas também pode ser justificado pelo fato destes canais serem encontrados como heterodímeros (166).

Independente da isoforma expressa, estes canais são responsáveis por manter o potencial de repouso em vários tipos de neurônios (43, 50), e no SON Erickson e colaboradores (42) demonstraram em cobaias, que estes canais estão envolvidos no controle da ritmicidade dos MNCs. A ativação tônica destes canais ajuda a manter o potencial de 
repouso em um nível despolarizado, enquanto a sua desativação leva o potencial de membrana para valores hiperpolarizados (124). Assim, avaliando a contribuição dos canais HCN na excitabilidade dos neurônios do SON evidenciamos que quando esses canais são bloqueados há uma redução na frequência de disparo, bem como no número de potenciais de ação frente a injeções de correntes despolarizantes (Figura 22). Todavia, não encontramos diferenças significativas na resistência de entrada dos neurônios na presença do ZD7288. Considerando a lei de Ohm, onde $\mathrm{V}=\mathrm{R}$.I, com um Ri elevado, pequenas alterações de corrente podem ocasionar alterações significativas no potencial de membrana. Em se tratando de células excitáveis, vale salientar que qualquer variação, mesmo que pequena, no potencial de membrana, pode ser suficiente para desencadear alterações na atividade celular. Assim, como exemplo, utilizando $\Delta \mathrm{I}=40 \mathrm{pA}$, com Ri de 1,1 G $\Omega$ (como encontrado neste estudo), teremos uma variação no $\mathrm{Vm}=-44 \mathrm{mV}$. Entretanto pequenas variações do Ri de $1.1 \mathrm{G} \Omega$ para $1 \mathrm{G} \Omega$ para um mesmo $\Delta \mathrm{I}=40 \mathrm{pA}$, resultará em uma variação no $\mathrm{Vm}$ de $-44 \mathrm{mV}$ para -40 $\mathrm{mV}$, ou seja, $4 \mathrm{mV}$ o que seria suficiente para causar grandes alterações na excitabilidade celular. O oposto será encontrado para Ri maiores que $1.1 \mathrm{G} \Omega$, ou seja, uma hiperpolarização do potencial de membrana. Portanto, considerando que o potencial de repouso criticamente determina o nível de excitabilidade dos neurônios e que, como descrito anteriormente, os canais $\mathrm{HCN}$ auxiliam na manutenção deste potencial podemos concluir que tais canais desempenham um importante papel na excitabilidade dos neurônios magnocelulares do SON. Nossos dados vão de encontro aos de Ghamari-Langroudi e Bourque (51), que demonstram um papel funcional da $I_{h}$ nos neurônios magnocelulares do núcleo supraóptico e sua contribuição na excitabilidade bem como nos disparos fásicos e tônicos dos MNCs. Adicionalmente, reforçando nossos dados estudos tem demonstrado que os canais $\mathrm{HCN}$ contribuem na determinação da excitabilidade neuronal de outros tipos celulares $(38,87,125)$. 


\subsection{Origem do NO e Modulação dos Canais HCN}

Antes de nos atermos as vias de sinalização utilizada pelo NO nos neurônios do SON, nos preocupamos em investigar a origem deste mensageiro neuronal. Na literatura encontramos que e osmolalidade plasmática acima de $300 \mathrm{mosm} / \mathrm{KgH}_{2} \mathrm{O}$ é um estímulo potente que aumenta a atividade elétrica dos MNCs em ratos $(24,84,151)$. Adicionalmente, ainda tem sido demonstrado que alterações da osmolalidade plasmática entre 310 a 330 mosm $/ \mathrm{KgH}_{2} \mathrm{O}$ resultam em um aumento da expressão de RNAm para NOS no núcleo supraóptico indicando que o NO pode estar envolvido no controle da excitabilidade dos MNCs, especialmente em situações em que a osmolalidade é comprometida. De fato, nós demonstramos recentemente que nestas situações experimentais o NO atua como um mensageiro inibitório ocasionando reduções na frequência de potenciais de ação dos MNCs, bem como alterações nas propriedades intrínsecas dos neurônios (34). Entretanto, apesar do estimulo hipertônico modular a atividade elétrica dos neurônios magnocelulares, e aumentar a expressão de RNAm para enzima catalisadora da formação do NO, ainda era desconhecido se estes neurônios eram capazes de produzir este mensageiro neuronal. No presente estudo demonstramos que o estímulo hipertônico induz aumento da produção de NO, efeito este abolido pelo bloqueador da NOS, L-NAME (Figura 20). Este aumento ocorreu independentemente do aumento da excitabilidade neuronal (Figura 21), que é observado com o estimulo hipertônico uma vez que estes neurônios operam como osmorreceptores (107). Demonstramos ainda, que apesar das células gliais serem capazes de produzir NO (100), e que durante estresse osmótico estas são ativadas segundos antes dos próprios neurônios magnocelulares $(104,109,112,116,131)$, o NO é produzido pelos MNCs uma vez que a mesma resposta foi observada nos neurônios isolados do SON (Figura 17). Nossos resultados coadunam-se com outros estudos que demonstraram um aumento de marcadores da produção do NO nos MNCs, tal como o NADPH - diaforase, RNAm e citrulina durante a estimulação 
hipertônica aguda ou crônica $(21,69,135,146)$. Como a produção do NO necessita do complexo cálcio calmodulina para ativar a nNOS, nós acreditamos que os canais ativados por estiramento (20), e canais TRPVs (16), presentes nessas células e ativados durante o estimulo hipertônico, são as vias de entrada para cálcio e consequente ativação da NOS. No entanto, tais hipóteses são apenas especulativas e necessitam ser testadas.

\subsection{Vias de Sinalização Nitrérgica nos Canais HCN}

O estudo das vias de sinalização utilizadas pelo NO para modular os canais HCN têm evidenciado, nos últimos anos, ser a ativação da guanilato ciclase (cGC) pelo NO, com consequente aumento na síntese de cGMP, o principal mecanismo de atuação intracelular do modulador $(6,22,162)$. As respostas mediadas pelo cGMP podem ocorrer por meio da ativação de proteínas quinases dependentes de cGMP, como também pela interação com canais iônios ativados por nucleotídeos cíclicos (72) incluindo os HCN (31). Em diferentes populações neuronais como cerebelo, neurônios talâmicos e motoneurônios do hipoglosso e trigêmios, os canais HCN, tem sido apontados com alvo potencial de modulação do NO via cGMP, $(1,113,155,156)$. No núcleo supraóptico tem sido relatado que o nitroprussiato de sódio, um doador de NO, aumenta a concentração de cGMP nos neurônios magnocelulares (32) que por sua vez induz um aumento do acoplamento neuronal (161). Consequentemente, tem sido sugerido que o NO desempenha um papel autorregulatório dependente de cGMP nesses neurônios. Neste mesmo trabalho, Yang e colaboradores observaram que 8-Br cGMP, um análogo do cGMP, aumenta a excitabilidade dos MNCs, um achado contraditório em relação à ação inibitória do NO sobre os neurônios magnocelulares encontrado previamente por nós $(34,147)$ e por outros $(83,103,141)$. Uma vez formado o cGMP pode desempenhar seu efeito por três vias distintas: 1) ativação de proteínas quinases com consequente alteração na concentração de cálcio intracelular; 2) ativação de fosfodiesterases que autorregulam sua 
atividade; e 3) efeitos diretos sobre canais iônios dependentes de nucleotídeo cíclico (45). Embora a maioria dos estudos aponte a guanilato ciclase como principal alvo do NO, alguns têm demonstrado que nos neurônios magnocelulares do SON, tanto em condições basais como na desidratação, a modulação nitrérgica da secreção de VP e OT (145), e sobre os canais para potássio ativados por cálcio do tipo BK (2) não envolve a formação de cGMP, em consonância com nossos resultados. Portanto, podemos observar que ainda há uma grande divergência a respeito do envolvimento do cGMP na sinalização do NO para diferentes situações.

Os achados do nosso estudo mostrando que cGMP não participa, como molécula sinalizadora, da modulação nitrérgica sobre as correntes $I_{h}$ foi uma surpresa devido ao fato da cGC ser descrita como o principal alvo fisiológico do NO no sistema nervoso central (48, 134). Por um lado, ainda pode surgir a dúvida se a concentração de ODQ utilizada foi suficiente para inibir completamente a atividade da guanilato ciclase. Como o ODQ é solúvel em DMSO, e este por sua vez tem demonstrado excitar os neurônios MNCs, aumentar a concentração da droga seria problemático. Por outro lado, trabalhos que utilizaram concentrações menores do que a nossa, observaram o bloqueio da ação do NO tanto no supraóptico como no paraventricular $(81,162)$ nos apontando o envolvimento de outras vias de sinalização.

\subsection{Modulação dos Canais HCN por S-nitrosilação}

Nos últimos anos, estudos têm sugerido algumas vias não convencionais de sinalização nitrérgica. Neste contexto, a visão clássica do cGMP como mediador exclusivo da modulação nitrérgica foi questionada por resultados mostrando que o NO pode modificar proteínas através de reações químicas diretas (90). Uma dessas modificações pós-traducionais da proteína ocorre nos grupamentos tiol de cadeias laterais de resíduos de cisteína. Este processo 
é denominado de S-nitrosilação, e ocorre através de um mecanismo químico complexo, sem o auxílio de enzimas (3). No sistema nervoso central este mecanismo foi descrito pela primeira vez em receptores glutamatérgicos do tipo NMDA, onde o resíduo de cisteína 399 da subunidade NR2A foi nitrosilado (30). Entretanto, outros estudos demonstram que o NO participa da modulação de proteínas de membrana incluindo canais iônicos, como os canais para potássio dependentes de cálcio (79), canais dependentes de nucleotídeos cíclicos (26), canais HCN (155), dentre outros (3). Como não há um bloqueador específico da Snitrosilação, neste estudo nós utilizamos o N-etilmaleimida (NEM) que oxida os resíduos de cisteína obstruindo a S-nitrosilação para avaliar se a modulação nitrérgica observada nos MNCs ocorria por meio deste mecanismo não convencional. Assim, observamos que na presença do NEM houve um aumento na corrente $\mathrm{I}_{\mathrm{h}}$ indicando que a oxidação dos resíduos de cisteína altera as propriedades intrínsecas dos canais HCN. Adicionalmente, quando a Larginina foi adicionada ao banho, nós não observamos alterações na corrente $I_{h}$, sugerindo uma possível via de modulação neste canal (Figura 23). Estes resultados são consistentes com os dados de Wenker e colaboradores (155), onde se demonstrou que o NO modula os canais HCN de motoneurônios do hipoglosso via S-nitrosilação dos resíduos Cis531 da porção carboxiterminal no HCN1 e Cis341 do HCN2 localizados na alça citoplasmática entre os segmentos S4 e S5.

Considerando a variedade e ubiquidade de proteínas cuja função pode ser regulada por S-nitrosilação $(78,89)$, esta modificação pode ser um componente importante no repertório de regulação dos canais iônicos, como aqui evidenciado. Fisiologicamente, a vantagem deste mecanismo se deve a estabilidade que a reação confere ao NO. Desta forma o NO pode ser tanto armazenado como transportado pelo organismo na forma nitrosilada (RSNO). Um exemplo é seu transporte pela glutationa, e também sua ligação à albumina e hemoglobina $(11,70,128)$. Embora a ligação do NO com os resíduos de cisteína ocorra de uma forma 
covalente, mecanismos de denitrosilação, S-glutationationa, nitração da tirosina, e ascorbato, são responsáveis por reverter esta interação $(11,39)$. Neste estudo nós avaliamos a presença de S-nitrosilação endógena utilizando como agente denitrosilante o ascorbato e evidenciamos um aumento significativo na corrente $\mathrm{I}_{\mathrm{h}}$. Tais resultados confirmam a presença de nitrosilação endógena nos canais $\mathrm{HCN}$ dos MNCs corroborando resultados de Jaffrey et al (64) que identificaram os canais HCN como substratos neurais para S-nitrosilação endógena.

\subsection{Modulação dos Canais HCN pelo NO Durante Estímulo Hipertônico}

Ainda que estudos anteriores tenham mostrado uma modulação na excitabilidade dos MNCs durante estímulos hipertônicos $(106,107)$, no presente estudo, nós demonstramos que este fenômeno é acompanhado por um aumento na produção de NO nos MNCs (Figura 20), sugerindo que este mensageiro neural pode estar também envolvido na modulação da excitabilidade dessas células, nestas condições experimentais. Esses dados estão de acordo com estudos prévios do nosso laboratório, onde mostramos que durante o estímulo hipertônico, o NO inibi a atividade dos MNCs, resultando em uma hiperpolarização do potencial de repouso e alterações na constate de tempo da fase de despolarização póspotencial (34), a qual está relacionada com o controle da excitabilidade desses neurônios (4, 19). Considerando que os canais HCN desempenham um papel importante na manutenção do potencial de repouso e que esses canais são, em parte, responsáveis pela fase de despolarização pós-potencial (51), nós avaliamos se o NO produzido durante o estresse osmótico também modula esses canais. Como demonstrado na figura 27, o estímulo hipertônico aumentou a corrente $\mathrm{I}_{\mathrm{h}}$ e um aumento adicional foi observado durante a inibição da NOS, demonstrando que o NO produzido durante as alterações de osmolalidade possui um efeito inibitório sobre a corrente $\mathrm{I}_{\mathrm{h}}$. Desta forma, o efeito do NO durante o estresse osmótico também apontam os canais HCN como alvo desta modulação. 
Nossos dados confirmam os achados de Kadowaki e colaboradores (69), onde os autores observaram que transcritos da NOS, tanto no PVN quanto no SON, aumentam após sobrecarga de salina reforçando a ideia de que o NO está envolvido nos mecanismos osmorregulatórios hipotalâmicos. Frente aos resultados inibitórios do NO sobre os canais HCN e consequentemente na excitabilidade dos MNCs durante o estímulo hipertônico, podemos especular que o NO é parte de um mecanismo de feedback negativo que evita a hiperatividade dos MNCs e, portanto, a liberação elevada de VP e OT pela neurohipófise. Nessas condições o sistema seria capaz de manter a síntese e liberação por tempo prolongado evitando a saturação deste sistema. 


\section{CONCLUSÕES}

Em suma, nossos dados nos permitem concluir que: 1) Em relação à caracterização do fenótipo celular, utilizando pela primeira vez três técnicas diferentes para caracterizar um único neurônio, o presente estudo sugere que, em preparações in vitro, o protocolo eletrofisiológico sozinho não descreve fielmente os fenótipos dos neurônios magnocelulares. Isto é particularmente crítico em situações onde o sistema necessita rearranjar-se, a fim de manter o equilíbrio hidroeletrolítico. Sendo assim, a combinação da detecção de RNAm e imunohistoquímica parece ser a melhor escolha ao tentar caracterizar um único fenótipo. E por fim, a excitabilidade elétrica dos neurônios magnocelulares do núcleo supraóptico é essencialmente determinada por um efeito de NO sobre correntes $I_{h}$ por um mecanismo dependente de S-nitrosilação. Deste modo, atuando em canais HCN, o NO representa outro modulador no complexo conjunto de mecanismos de controle da homeostase dos líquidos corporais. 


\section{REFERÊNCIAS BIBLIOGRÁGICAS}

1. Abudara V, Alvarez AF, Chase MH, and Morales FR. Nitric oxide as an anterograde neurotransmitter in the trigeminal motor pool. $J$ Neurophysiol 88: 497-506, 2002.

2. Ahern GP, Hsu SF, and Jackson MB. Direct actions of nitric oxide on rat neurohypophysial K+ channels. J Physiol 520 Pt 1: 165-176, 1999.

3. Ahern GP, Klyachko VA, and Jackson MB. cGMP and S-nitrosylation: two routes for modulation of neuronal excitability by NO. Trends Neurosci 25: 510-517, 2002.

4. Andrew RD, and Dudek FE. Intrinsic inhibition in magnocellular neuroendocrine cells of rat hypothalamus. J Physiol 353: 171-185, 1984.

5. Antunes-Rodrigues J, Ruginsk SG, Mecawi AS, Margatho LO, Reis WL, Ventura RR, da Silva AL, Vilhena-Franco T, and Elias LLK. Neuroendocrinology of Hydromineral Homeostasis. In: De Luca LA, Menani JV, Johnson AK, editors Neurobiology of Body Fluid Homeostasis: Transduction and Integration Boca Raton (FL): CRC Press; 2014 Chapter 3 2014.

6. Archer SL, Huang JM, Hampl V, Nelson DP, Shultz PJ, and Weir EK. Nitric oxide and cGMP cause vasorelaxation by activation of a charybdotoxin-sensitive $\mathrm{K}$ channel by cGMP-dependent protein kinase. Proc Natl Acad Sci U S A 91: 7583-7587, 1994.

7. Armstrong WE. Morphological and electrophysiological classification of hypothalamic supraoptic neurons. Prog Neurobiol 47: 291-339, 1995.

8. Armstrong WE, and Stern JE. Electrophysiological distinctions between oxytocin and vasopressin neurons in the supraoptic nucleus. Adv Exp Med Biol 449: 67-77, 1998.

9. Baertschi AJ, and Vallet PG. Osmosensitivity of the hepatic portal vein area and vasopressin release in rats. J Physiol 315: 217-230, 1981.

10. Baldino F, Jr., O'Kane TM, Fitzpatrick-McElligott S, and Wolfson B. Coordinate hormonal and synaptic regulation of vasopressin messenger RNA. Science 241: 978-981, 1988.

11. Benhar M, Forrester MT, and Stamler JS. Protein denitrosylation: enzymatic mechanisms and cellular functions. Nat Rev Mol Cell Biol 10: 721-732, 2009.

12. Bhat G, Mahesh VB, Aguan K, and Brann DW. Evidence that brain nitric oxide synthase is the major nitric oxide synthase isoform in the hypothalamus of the adult female rat and that nitric oxide potently regulates hypothalamic cGMP levels. Neuroendocrinology 64: 93-102, 1996.

13. Biel M, Wahl-Schott C, Michalakis S, and Zong X. Hyperpolarization-activated cation channels: from genes to function. Physiol Rev 89: 847-885, 2009.

14. Boudaba C, Linn DM, Halmos KC, and Tasker JG. Increased tonic activation of presynaptic metabotropic glutamate receptors in the rat supraoptic nucleus following chronic dehydration. J Physiol 551: 815-823, 2003.

15. Bourque $\mathbf{C W}$. Ionic basis for the intrinsic activation of rat supraoptic neurones by hyperosmotic stimuli. J Physiol 417: 263-277, 1989.

16. Bourque CW, Guilak F, and Liedtke W. A TRP that makes us feel hyper. J Physiol 590: 1779-1780, 2012.

17. Bourque CW, and Oliet SH. Osmoreceptors in the central nervous system. Annu Rev Physiol 59: 601-619, 1997.

18. Bourque CW, Oliet SH, and Richard D. Osmoreceptors, osmoreception, and osmoregulation. Front Neuroendocrinol 15: 231-274, 1994.

19. Bourque CW, Randle JC, and Renaud LP. Calcium-dependent potassium conductance in rat supraoptic nucleus neurosecretory neurons. J Neurophysiol 54: 1375-1382, 1985 . 
20. Bourque CW, Voisin DL, and Chakfe Y. Stretch-inactivated cation channels: cellular targets for modulation of osmosensitivity in supraoptic neurons. Prog Brain Res 139: 85-94, 2002.

21. Bredt DS, Glatt CE, Hwang PM, Fotuhi M, Dawson TM, and Snyder SH. Nitric oxide synthase protein and mRNA are discretely localized in neuronal populations of the mammalian CNS together with NADPH diaphorase. Neuron 7: 615-624, 1991.

22. Bredt DS, and Snyder SH. Nitric oxide mediates glutamate-linked enhancement of cGMP levels in the cerebellum. Proc Natl Acad Sci U S A 86: 9030-9033, 1989.

23. Brenner BM, Ballermann BJ, Gunning ME, and Zeidel ML. Diverse biological actions of atrial natriuretic peptide. Physiol Rev 70: 665-699, 1990.

24. Brimble MJ, and Dyball RE. Characterization of the responses of oxytocin- and vasopressin-secreting neurones in the supraoptic nucleus to osmotic stimulation. $J$ Physiol 271: 253-271, 1977.

25. Broillet MC. S-nitrosylation of proteins. Cell Mol Life Sci 55: 1036-1042, 1999.

26. Broillet MC, and Firestein S. Direct activation of the olfactory cyclic nucleotidegated channel through modification of sulfhydryl groups by NO compounds. Neuron 16: 377385, 1996.

27. Bush PA, Gonzalez NE, Griscavage JM, and Ignarro LJ. Nitric oxide synthase from cerebellum catalyzes the formation of equimolar quantities of nitric oxide and citrulline from L-arginine. Biochem Biophys Res Commun 185: 960-966, 1992.

28. Calabrese V, Mancuso C, Calvani M, Rizzarelli E, Butterfield DA, and Stella AM. Nitric oxide in the central nervous system: neuroprotection versus neurotoxicity. Nat Rev Neurosci 8: 766-775, 2007.

29. Choi-Kwon S, and Baertschi AJ. Splanchnic osmosensation and vasopressin: mechanisms and neural pathways. Am J Physiol 261: E18-25, 1991.

30. Choi YB, Tenneti L, Le DA, Ortiz J, Bai G, Chen HS, and Lipton SA. Molecular basis of NMDA receptor-coupled ion channel modulation by S-nitrosylation. Nat Neurosci 3: $15-21,2000$.

31. Craven KB, and Zagotta WN. CNG and HCN channels: two peas, one pod. Annu Rev Physiol 68: 375-401, 2006.

32. Cui LN, Inenaga K, Nagatomo $\mathbf{T}$, and Yamashita $\mathbf{H}$. Sodium nitroprusside modulates NMDA response in the rat supraoptic neurons in vitro. Brain Res Bull 35: 253-260, 1994.

33. da Silva MP, Cedraz-Mercez PL, and Varanda WA. Effects of nitric oxide on magnocellular neurons of the supraoptic nucleus involve multiple mechanisms. Braz J Med Biol Res 47: 90-100, 2014.

34. da Silva MP, Ventura RR, and Varanda WA. Hypertonicity increases NO production to modulate the firing rate of magnocellular neurons of the supraoptic nucleus of rats. Neuroscience 250: 70-79, 2013.

35. Dawson TM, and Dawson VL. Nitric oxide synthase: role as a transmitter/mediator in the brain and endocrine system. Annu Rev Med 47: 219-227, 1996.

36. Dawson VL, Brahmbhatt HP, Mong JA, and Dawson TM. Expression of inducible nitric oxide synthase causes delayed neurotoxicity in primary mixed neuronal-glial cortical cultures. Neuropharmacology 33: 1425-1430, 1994.

37. Decavel C, and Van den Pol AN. GABA: a dominant neurotransmitter in the hypothalamus. J Comp Neurol 302: 1019-1037, 1990.

38. Deng WS, Jiang YX, Han XH, Xue Y, Wang H, Sun P, and Chen L. HCN Channels Modulate the Activity of the Subthalamic Nucleus In Vivo. J Mol Neurosci 2014.

39. Derakhshan B, Wille PC, and Gross SS. Unbiased identification of cysteine Snitrosylation sites on proteins. Nat Protoc 2: 1685-1691, 2007. 
40. Dutton A, and Dyball RE. Phasic firing enhances vasopressin release from the rat neurohypophysis. J Physiol 290: 433-440, 1979.

41. El Majdoubi M, Poulain DA, and Theodosis DT. The glutamatergic innervation of oxytocin- and vasopressin-secreting neurons in the rat supraoptic nucleus and its contribution to lactation-induced synaptic plasticity. Eur J Neurosci 8: 1377-1389, 1996.

42. Erickson KR, Ronnekleiv OK, and Kelly MJ. Electrophysiology of guinea-pig supraoptic neurones: role of a hyperpolarization-activated cation current in phasic firing. $J$ Physiol 460: 407-425, 1993.

43. Fan Y, Fricker D, Brager DH, Chen X, Lu HC, Chitwood RA, and Johnston D. Activity-dependent decrease of excitability in rat hippocampal neurons through increases in I(h). Nat Neurosci 8: 1542-1551, 2005.

44. Forstermann U, Gath I, Schwarz P, Closs EI, and Kleinert H. Isoforms of nitric oxide synthase. Properties, cellular distribution and expressional control. Biochem Pharmacol 50: 1321-1332, 1995.

45. Francis SH, Busch JL, Corbin JD, and Sibley D. cGMP-dependent protein kinases and cGMP phosphodiesterases in nitric oxide and cGMP action. Pharmacol Rev 62: 525-563, 2010 .

46. Gainer H. Cell-type specific expression of oxytocin and vasopressin genes: an experimental odyssey. J Neuroendocrinol 24: 528-538, 2012.

47. Garthwaite J. Concepts of neural nitric oxide-mediated transmission. Eur J Neurosci 27: 2783-2802, 2008.

48. Garthwaite J. Glutamate, nitric oxide and cell-cell signalling in the nervous system. Trends Neurosci 14: 60-67, 1991.

49. Garthwaite J, and Boulton CL. Nitric oxide signaling in the central nervous system. Annu Rev Physiol 57: 683-706, 1995.

50. Gasparini S, and DiFrancesco D. Action of the hyperpolarization-activated current (Ih) blocker ZD 7288 in hippocampal CA1 neurons. Pflugers Arch 435: 99-106, 1997.

51. Ghamari-Langroudi M, and Bourque CW. Excitatory role of the hyperpolarizationactivated inward current in phasic and tonic firing of rat supraoptic neurons. J Neurosci 20: 4855-4863, 2000.

52. Glasgow E, Kusano K, Chin H, Mezey E, Young WS, 3rd, and Gainer H. Single cell reverse transcription-polymerase chain reaction analysis of rat supraoptic magnocellular neurons: neuropeptide phenotypes and high voltage-gated calcium channel subtypes. Endocrinology 140: 5391-5401, 1999.

53. Gordon GR, Baimoukhametova DV, Hewitt SA, Rajapaksha WR, Fisher TE, and Bains JS. Norepinephrine triggers release of glial ATP to increase postsynaptic efficacy. Nat Neurosci 8: 1078-1086, 2005.

54. Gouzenes L, Desarmenien MG, Hussy N, Richard P, and Moos FC. Vasopressin regularizes the phasic firing pattern of rat hypothalamic magnocellular vasopressin neurons. $J$ Neurosci 18: 1879-1885, 1998.

55. Guo Y, Xiao P, Lei S, Deng F, Xiao GG, Liu Y, Chen X, Li L, Wu S, Chen Y, Jiang H, Tan L, Xie J, Zhu X, Liang S, and Deng $\mathbf{H}$. How is mRNA expression predictive for protein expression? A correlation study on human circulating monocytes. Acta Biochim Biophys Sin (Shanghai) 40: 426-436, 2008.

56. Gygi SP, Rochon Y, Franza BR, and Aebersold R. Correlation between protein and mRNA abundance in yeast. Mol Cell Biol 19: 1720-1730, 1999.

57. Hara Y, Battey J, and Gainer H. Structure of mouse vasopressin and oxytocin genes. Brain Res Mol Brain Res 8: 319-324, 1990. 
58. Hawrylak N, Fleming JC, and Salm AK. Dehydration and rehydration selectively and reversibly alter glial fibrillary acidic protein immunoreactivity in the rat supraoptic nucleus and subjacent glial limitans. Glia 22: 260-271, 1998.

59. Heid CA, Stevens J, Livak KJ, and Williams PM. Real time quantitative PCR. Genome Res 6: 986-994, 1996.

60. Hess DT, Matsumoto A, Kim SO, Marshall HE, and Stamler JS. Protein Snitrosylation: purview and parameters. Nat Rev Mol Cell Biol 6: 150-166, 2005.

61. Hirasawa M, Mouginot D, Kozoriz MG, Kombian SB, and Pittman QJ. Vasopressin differentially modulates non-NMDA receptors in vasopressin and oxytocin neurons in the supraoptic nucleus. J Neurosci 23: 4270-4277, 2003.

62. Hoyda TD, Fry M, Ahima RS, and Ferguson AV. Adiponectin selectively inhibits oxytocin neurons of the paraventricular nucleus of the hypothalamus. $J$ Physiol 585: 805-816, 2007.

63. Huang W, Lee SL, and Sjoquist M. Natriuretic role of endogenous oxytocin in male rats infused with hypertonic NaCl. Am J Physiol 268: R634-640, 1995.

64. Jaffrey SR, Erdjument-Bromage H, Ferris CD, Tempst P, and Snyder SH. Protein S-nitrosylation: a physiological signal for neuronal nitric oxide. Nat Cell Biol 3: 193-197, 2001.

65. Johnson AK, and Gross PM. Sensory circumventricular organs and brain homeostatic pathways. FASEB J 7: 678-686, 1993.

66. Johnson AK, and Thunhorst RL. The neuroendocrinology of thirst and salt appetite: visceral sensory signals and mechanisms of central integration. Front Neuroendocrinol 18: 292-353, 1997.

67. Kadekaro M. Nitric oxide modulation of the hypothalamo-neurohypophyseal system. Braz J Med Biol Res 37: 441-450, 2004.

68. Kadekaro M, Su G, Chu R, Lei Y, Li J, and Fang L. Effects of nitric oxide on expressions of nitrosocysteine and calcium-activated potassium channels in the supraoptic nuclei and neural lobe of dehydrated rats. Neurosci Lett 411: 117-122, 2007.

69. Kadowaki K, Kishimoto J, Leng G, and Emson PC. Up-regulation of nitric oxide synthase (NOS) gene expression together with NOS activity in the rat hypothalamohypophysial system after chronic salt loading: evidence of a neuromodulatory role of nitric oxide in arginine vasopressin and oxytocin secretion. Endocrinology 134: 1011-1017, 1994.

70. Kagan VE, Day BW, Elsayed NM, and Gorbunov NV. Dynamics of haemoglobin. Nature 383: 30-31, 1996.

71. Kase D, and Imoto K. The Role of HCN Channels on Membrane Excitability in the Nervous System. J Signal Transduct 2012: 619747, 2012.

72. Kaupp UB, and Seifert R. Cyclic nucleotide-gated ion channels. Physiol Rev 82: 769-824, 2002.

73. Kawata M, McCabe JT, and Pfaff DW. In situ hybridization histochemistry with oxytocin synthetic oligonucleotide: strategy for making the probe and its application. Brain Res Bull 20: 693-697, 1988.

74. Kiyama H, and Emson PC. Evidence for the co-expression of oxytocin and vasopressin messenger ribonucleic acids in magnocellular neurosecretory cells: simultaneous demonstration of two neurohypophysin messenger ribonucleic acids by hybridization histochemistry. J Neuroendocrinol 2: 257-259, 1990.

75. Kleinert H, Pautz A, Linker K, and Schwarz PM. Regulation of the expression of inducible nitric oxide synthase. Eur J Pharmacol 500: 255-266, 2004.

76. Knobloch HS, Charlet A, Hoffmann LC, Eliava M, Khrulev S, Cetin AH, Osten P, Schwarz MK, Seeburg PH, Stoop R, and Grinevich V. Evoked axonal oxytocin release in the central amygdala attenuates fear response. Neuron 73: 553-566, 2012. 
77. Krukoff TL. Central actions of nitric oxide in regulation of autonomic functions. Brain Res Brain Res Rev 30: 52-65, 1999.

78. Lander HM, Hajjar DP, Hempstead BL, Mirza UA, Chait BT, Campbell S, and Quilliam LA. A molecular redox switch on p21(ras). Structural basis for the nitric oxidep21(ras) interaction. J Biol Chem 272: 4323-4326, 1997.

79. Lang RJ, Harvey JR, McPhee GJ, and Klemm MF. Nitric oxide and thiol reagent modulation of $\mathrm{Ca} 2+$-activated $\mathrm{K}+(\mathrm{BKCa})$ channels in myocytes of the guinea-pig taenia caeci. J Physiol 525 Pt 2: 363-376, 2000.

80. Li C, Tripathi PK, and Armstrong WE. Differences in spike train variability in rat vasopressin and oxytocin neurons and their relationship to synaptic activity. $J$ Physiol 581: 221-240, 2007.

81. Li DP, Chen SR, Finnegan TF, and Pan HL. Signalling pathway of nitric oxide in synaptic GABA release in the rat paraventricular nucleus. J Physiol 554: 100-110, 2004.

82. Li WC, Soffe SR, and Roberts A. A direct comparison of whole cell patch and sharp electrodes by simultaneous recording from single spinal neurons in frog tadpoles. $J$ Neurophysiol 92: 380-386, 2004.

83. Liu QS, Jia YS, and Ju G. Nitric oxide inhibits neuronal activity in the supraoptic nucleus of the rat hypothalamic slices. Brain Res Bull 43: 121-125, 1997.

84. Ludwig M, Callahan MF, Neumann I, Landgraf R, and Morris M. Systemic osmotic stimulation increases vasopressin and oxytocin release within the supraoptic nucleus. J Neuroendocrinol 6: 369-373, 1994.

85. Ludwig M, Johnstone LE, Neumann I, Landgraf R, and Russell JA. Direct hypertonic stimulation of the rat supraoptic nucleus increases c-fos expressionin glial cells rather than magnocellular neurones. Cell Tissue Res 287: 79-90, 1997.

86. Ludwig M, and Leng G. Dendritic peptide release and peptide-dependent behaviours. Nat Rev Neurosci 7: 126-136, 2006.

87. Maccaferri G, and McBain CJ. The hyperpolarization-activated current (Ih) and its contribution to pacemaker activity in rat CA1 hippocampal stratum oriens-alveus interneurones. J Physiol 497 ( Pt 1): 119-130, 1996.

88. Maier T, Guell M, and Serrano L. Correlation of mRNA and protein in complex biological samples. FEBS Lett 583: 3966-3973, 2009.

89. Mannick JB, Miao XQ, and Stamler JS. Nitric oxide inhibits Fas-induced apoptosis. J Biol Chem 272: 24125-24128, 1997.

90. Martinez-Ruiz A, Cadenas S, and Lamas S. Nitric oxide signaling: classical, less classical, and nonclassical mechanisms. Free radical biology \& medicine 51: 17-29, 2011.

91. Mason WT. Supraoptic neurones of rat hypothalamus are osmosensitive. Nature 287: 154-157, 1980.

92. Meeker RB, Greenwood RS, and Hayward JN. Vasopressin mRNA expression in individual magnocellular neuroendocrine cells of the supraoptic and paraventricular nucleus in response to water deprivation. Neuroendocrinology 54: 236-247, 1991.

93. Merino RM, and Varanda WA. Efeito do hormônio liberador de tireotrofina (TRH) sobre a atividade elétrica de neurônios magnocelulares do núcleo supraóptico de ratos. 2012.

94. Mezey E, and Kiss JZ. Coexpression of vasopressin and oxytocin in hypothalamic supraoptic neurons of lactating rats. Endocrinology 129: 1814-1820, 1991.

95. Mohr E, Schmitz E, and Richter D. A single rat genomic DNA fragment encodes both the oxytocin and vasopressin genes separated by 11 kilobases and oriented in opposite transcriptional directions. Biochimie 70: 649-654, 1988.

96. Monteggia LM, Eisch AJ, Tang MD, Kaczmarek LK, and Nestler EJ. Cloning and localization of the hyperpolarization-activated cyclic nucleotide-gated channel family in rat brain. Brain Res Mol Brain Res 81: 129-139, 2000. 
97. Moos FC, and Ingram CD. Electrical recordings of magnocellular supraoptic and paraventricular neurons displaying both oxytocin- and vasopressin-related activity. Brain Res 669: 309-314, 1995.

98. Mori M, and Gotoh T. Regulation of nitric oxide production by arginine metabolic enzymes. Biochem Biophys Res Commun 275: 715-719, 2000.

99. Murphy D, and Wells S. In vivo gene transfer studies on the regulation and function of the vasopressin and oxytocin genes. J Neuroendocrinol 15: 109-125, 2003.

100. Murphy S, Simmons ML, Agullo L, Garcia A, Feinstein DL, Galea E, Reis DJ, Minc-Golomb D, and Schwartz JP. Synthesis of nitric oxide in CNS glial cells. Trends Neurosci 16: 323-328, 1993.

101. Murray HE, Simonian SX, Herbison AE, and Gillies GE. Correlation of hypothalamic somatostatin mRNA expression and peptide content with secretion: sexual dimorphism and differential regulation by gonadal factors. J Neuroendocrinol 11: 27-33, 1999.

102. Notomi T, and Shigemoto R. Immunohistochemical localization of Ih channel subunits, HCN1-4, in the rat brain. J Comp Neurol 471: 241-276, 2004.

103. Okere CO, and Higuchi T. Down-regulation of endogenous nitric oxide synthase in late-pregnancy and parturition in the rat hypothalamic magnocellular neurons and neurohypophysis. Neurosci Lett 220: 133-136, 1996.

104. Oliet SH. Functional consequences of morphological neuroglial changes in the magnocellular nuclei of the hypothalamus. J Neuroendocrinol 14: 241-246, 2002.

105. Oliet SH, and Bourque CW. Mechanosensitive channels transduce osmosensitivity in supraoptic neurons. Nature 364: 341-343, 1993.

106. Oliet SH, and Bourque CW. Osmoreception in magnocellular neurosecretory cells: from single channels to secretion. Trends Neurosci 17: 340-344, 1994.

107. Oliet SH, and Bourque CW. Properties of supraoptic magnocellular neurones isolated from the adult rat. J Physiol 455: 291-306, 1992.

108. Oliet SH, and Bourque CW. Steady-state osmotic modulation of cationic conductance in neurons of rat supraoptic nucleus. Am J Physiol 265: R1475-1479, 1993.

109. Oliet SH, Panatier A, and Piet R. Functional neuronal-glial anatomical remodelling in the hypothalamus. Novartis Found Symp 276: 238-248; discussion 248-252, 275-281, 2006.

110. Oliet SH, Piet R, and Poulain DA. Control of glutamate clearance and synaptic efficacy by glial coverage of neurons. Science 292: 923-926, 2001.

111. Ozaki M, Shibuya I, Kabashima N, Isse T, Noguchi J, Ueta Y, Inoue Y, Shigematsu A, and Yamashita H. Preferential potentiation by nitric oxide of spontaneous inhibitory postsynaptic currents in rat supraoptic neurones. J Neuroendocrinol 12: 273-281, 2000.

112. Panatier A, and Oliet SH. Neuron-glia interactions in the hypothalamus. Neuron Glia Biol 2: 51-58, 2006.

113. Pape HC, and Mager R. Nitric oxide controls oscillatory activity in thalamocortical neurons. Neuron 9: 441-448, 1992.

114. Paulsen RE, Contestabile A, Villani L, and Fonnum F. An in vivo model for studying function of brain tissue temporarily devoid of glial cell metabolism: the use of fluorocitrate. J Neurochem 48: 1377-1385, 1987.

115. Paxinos G, and Watson C. The Rat Brain in Steriotaxic Coordinates. San Diego: 2007.

116. Piet R, Poulain DA, and Oliet SH. Modulation of synaptic transmission by astrocytes in the rat supraoptic nucleus. J Physiol Paris 96: 231-236, 2002. 
117. Ponzio TA, Fields RL, Rashid OM, Salinas YD, Lubelski D, and Gainer H. Celltype specific expression of the vasopressin gene analyzed by AAV mediated gene delivery of promoter deletion constructs into the rat SON in vivo. PLoS One 7: e48860, 2012.

118. Poulain DA, and Wakerley JB. Electrophysiology of hypothalamic magnocellular neurones secreting oxytocin and vasopressin. Neuroscience 7: 773-808, 1982.

119. Poulain DA, Wakerley JB, and Dyball RE. Electrophysiological differentiation of oxytocin- and vasopressin-secreting neurones. Proc R Soc Lond B Biol Sci 196: 367-384, 1977.

120. Price CJ, Samson WK, and Ferguson AV. Neuropeptide W has cell phenotypespecific effects on the excitability of different subpopulations of paraventricular nucleus neurones. J Neuroendocrinol 21: 850-857, 2009.

121. Pryor WA, and Squadrito GL. The chemistry of peroxynitrite: a product from the reaction of nitric oxide with superoxide. Am J Physiol 268: L699-722, 1995.

122. Rhodes CH, Morrell JI, and Pfaff DW. Immunohistochemical analysis of magnocellular elements in rat hypothalamus: distribution and numbers of cells containing neurophysin, oxytocin, and vasopressin. J Comp Neurol 198: 45-64, 1981.

123. Richard D, and Bourque CW. Synaptic control of rat supraoptic neurones during osmotic stimulation of the organum vasculosum lamina terminalis in vitro. J Physiol 489 ( $\mathrm{Pt}$ 2): 567-577, 1995.

124. Robinson RB, and Siegelbaum SA. Hyperpolarization-activated cation currents: from molecules to physiological function. Annu Rev Physiol 65: 453-480, 2003.

125. Rodrigues AR, and Oertel D. Hyperpolarization-activated currents regulate excitability in stellate cells of the mammalian ventral cochlear nucleus. J Neurophysiol 95: 76-87, 2006.

126. Salm AK. Mechanisms of glial retraction in the hypothalamo-neurohypophysial system of the rat. Exp Physiol 85 Spec No: 197S-202S, 2000.

127. Salm AK, and Bobak JB. Dehydration-associated changes in the ventral glial limitans subjacent to the supraoptic nucleus include a reduction in the extent of the basal lamina but not astrocytic process shrinkage. Exp Neurol 160: 425-432, 1999.

128. Scharfstein JS, Keaney JF, Jr., Slivka A, Welch GN, Vita JA, Stamler JS, and Loscalzo J. In vivo transfer of nitric oxide between a plasma protein-bound reservoir and low molecular weight thiols. J Clin Invest 94: 1432-1439, 1994.

129. Silva MP, Ventura RR, and Varanda WA. Nitrergic modulation of excitability of SON magnocellular neurons. In: Department of Physiology. Ribeirao Preto: School of Medicine of Ribeirao Preto -University of Sao Paulo, 2010, p. 92.

130. Silva PM. Modulação Nitrérgica da Excitabilidade de Neurônios Magnocelulares do Núcleo Supraóptico. In: Departamento de Fisiologia. Ribeirão Preto: Universidade de São Paulo, 2010, p. 93.

131. Simard M, and Nedergaard M. The neurobiology of glia in the context of water and ion homeostasis. Neuroscience 129: 877-896, 2004.

132. Sjoquist M, Huang W, Jacobsson E, Lee SL, and Ulfendahl HR. Natriuretic role of oxytocin in sodium homeostasis in rats. Adv Exp Med Biol 395: 353-354, 1995.

133. Sladek CD, and Kapoor JR. Neurotransmitter/neuropeptide interactions in the regulation of neurohypophyseal hormone release. Exp Neurol 171: 200-209, 2001.

134. Southam E, and Garthwaite J. The nitric oxide-cyclic GMP signalling pathway in rat brain. Neuropharmacology 32: 1267-1277, 1993.

135. Srisawat R, Bishop VR, Bull PM, Douglas AJ, Russell JA, Ludwig M, and Leng G. Regulation of neuronal nitric oxide synthase mRNA expression in the rat magnocellular neurosecretory system. Neurosci Lett 369: 191-196, 2004. 
136. Stachniak TJ, Trudel E, and Bourque CW. Cell-specific retrograde signals mediate antiparallel effects of angiotensin II on osmoreceptor afferents to vasopressin and oxytocin neurons. Cell Rep 8: 355-362, 2014.

137. Staley KJ, Otis TS, and Mody I. Membrane properties of dentate gyrus granule cells: comparison of sharp microelectrode and whole-cell recordings. J Neurophysiol 67: 13461358, 1992.

138. Stamler JS, and Toone EJ. The decomposition of thionitrites. Curr Opin Chem Biol 6: 779-785, 2002.

139. Stern JE, and Armstrong WE. Electrophysiological differences between oxytocin and vasopressin neurones recorded from female rats in vitro. J Physiol 488 ( Pt 3): 701-708, 1995.

140. Stern JE, and Armstrong WE. Sustained outward rectification of oxytocinergic neurones in the rat supraoptic nucleus: ionic dependence and pharmacology. J Physiol 500 ( Pt 2): 497-508, 1997.

141. Stern JE, and Ludwig M. NO inhibits supraoptic oxytocin and vasopressin neurons via activation of GABAergic synaptic inputs. Am J Physiol Regul Integr Comp Physiol 280: R1815-1822, 2001.

142. Stuart G, and Sakmann B. Amplification of EPSPs by axosomatic sodium channels in neocortical pyramidal neurons. Neuron 15: 1065-1076, 1995.

143. Sucher NJ, and Deitcher DL. PCR and patch-clamp analysis of single neurons. Neuron 14: 1095-1100, 1995.

144. Summy-Long JY, Bui V, Mantz S, Koehler E, Weisz J, and Kadekaro M. Central inhibition of nitric oxide synthase preferentially augments release of oxytocin during dehydration. Neurosci Lett 152: 190-193, 1993.

145. Terrell ML, Salas N, Bui V, Summy-Long JY, and Kadekaro M. NO inhibition of the magnocellular neuroendocrine system in rats is independent of cGMP signaling pathway. Exp Neurol 184: 846-856, 2003.

146. Ueta Y, Levy A, Chowdrey HS, and Lightman SL. Water deprivation in the rat induces nitric oxide synthase (NOS) gene expression in the hypothalamic paraventricular and supraoptic nuclei. Neurosci Res 23: 317-319, 1995.

147. Ventura RR, Aguiar JF, Antunes-Rodrigues J, and Varanda WA. Nitric oxide modulates the firing rate of the rat supraoptic magnocellular neurons. Neuroscience 155: 359$365,2008$.

148. Ventura RR, Giusti-Paiva A, Gomes DA, Elias LL, and Antunes-Rodrigues J. Neuronal nitric oxide synthase inhibition differentially affects oxytocin and vasopressin secretion in salt loaded rats. Neurosci Lett 379: 75-80, 2005.

149. Verbalis JG, Mangione MP, and Stricker EM. Oxytocin produces natriuresis in rats at physiological plasma concentrations. Endocrinology 128: 1317-1322, 1991.

150. Vincent SR, and Kimura H. Histochemical mapping of nitric oxide synthase in the rat brain. Neuroscience 46: 755-784, 1992.

151. Voisin DL, Chakfe Y, and Bourque CW. Coincident detection of CSF $\mathrm{Na}+$ and osmotic pressure in osmoregulatory neurons of the supraoptic nucleus. Neuron 24: 453-460, 1999.

152. Wahl-Schott $\mathbf{C}$, and Biel $\mathbf{M}$. HCN channels: structure, cellular regulation and physiological function. Cell Mol Life Sci 66: 470-494, 2009.

153. Wakerley JB, Poulain DA, and Brown D. Comparison of firing patterns in oxytocinand vasopressin-releasing neurones during progressive dehydration. Brain Res 148: 425-440, 1978.

154. Watts AG, and Boyle CN. The functional architecture of dehydration-anorexia. Physiol Behav 100: 472-477. 
155. Wenker IC, Benoit JP, Chen X, Liu H, Horner RL, and Mulkey DK. Nitric oxide activates hypoglossal motoneurons by cGMP-dependent inhibition of TASK channels and cGMP-independent activation of HCN channels. J Neurophysiol 107: 1489-1499, 2012.

156. Wilson GW, and Garthwaite J. Hyperpolarization-activated ion channels as targets for nitric oxide signalling in deep cerebellar nuclei. Eur J Neurosci 31: 1935-1945, 2010.

157. Wink DA, Cook JA, Christodoulou D, Krishna MC, Pacelli R, Kim S, DeGraff W, Gamson J, Vodovotz Y, Russo A, and Mitchell JB. Nitric oxide and some nitric oxide donor compounds enhance the cytotoxicity of cisplatin. Nitric Oxide 1: 88-94, 1997.

158. Wu X, Liao L, Liu X, Luo F, Yang T, and Li C. Is ZD7288 a selective blocker of hyperpolarization-activated cyclic nucleotide-gated channel currents? Channels (Austin) 6: 438-442, 2012.

159. Xi D, Kusano K, and Gainer H. Quantitative analysis of oxytocin and vasopressin messenger ribonucleic acids in single magnocellular neurons isolated from supraoptic nucleus of rat hypothalamus. Endocrinology 140: 4677-4682, 1999.

160. Yamashita H, Inenaga K, Kawata M, and Sano Y. Phasically firing neurons in the supraoptic nucleus of the rat hypothalamus: immunocytochemical and electrophysiological studies. Neurosci Lett 37: 87-92, 1983.

161. Yang QZ, and Hatton GI. Direct evidence for electrical coupling among rat supraoptic nucleus neurons. Brain Res 463: 47-56, 1988.

162. Yang QZ, and Hatton GI. Nitric oxide via cGMP-dependent mechanisms increases dye coupling and excitability of rat supraoptic nucleus neurons. J Neurosci 19: 4270-4279, 1999.

163. Yuan H, Gao B, Duan L, Jiang S, Cao R, Xiong YF, and Rao ZR. Acute hyperosmotic stimulus-induced Fos expression in neurons depends on activation of astrocytes in the supraoptic nucleus of rats. J Neurosci Res 88: 1364-1373, 2010.

164. Yuan Z, Liu B, Yuan L, Zhang Y, Dong X, and Lu J. Evidence of nuclear localization of neuronal nitric oxide synthase in cultured astrocytes of rats. Life Sciences 74: 3199-3209, 2004.

165. Zampronio AR, Kuzmiski JB, Florence CM, Mulligan SJ, and Pittman QJ. Opposing actions of endothelin-1 on glutamatergic transmission onto vasopressin and oxytocin neurons in the supraoptic nucleus. J Neurosci 30: 16855-16863, 2010.

166. Zha Q, Brewster AL, Richichi C, Bender RA, and Baram TZ. Activity-dependent heteromerization of the hyperpolarization-activated, cyclic-nucleotide gated (HCN) channels: role of N-linked glycosylation. J Neurochem 105: 68-77, 2008. 
8. PUBLICAÇÕES 